\title{
Characterization Activities to Determine the Extent of DNAPL in the Vadose Zone at the A-014 Outfall of A/M Area
}

by

D. G. Jackson

Westinghouse Savannah River Company

Savannah River Site

Aiken, South Carolina 29808

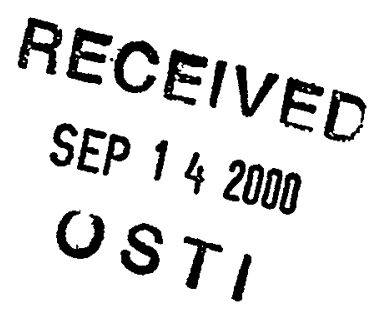

W. K. Hyde

J. Rossabl

B. D. Ring

DOE Contract No. DE-AC09-96SR18500

This paper was prepared in connection with work done under the above contract number with the U.S. Department of Energy. By acceptance of this paper, the publisher and/or recipient acknowledges the U.S. Government's right to retain a nonexclusive, royalty-free license in and to any copyright covering this paper, along with the right to reproduce and to authorize others to reproduce all or part of the copyrighted paper. 


\section{Characterization Activities to Determine the Extent of DNAPL in the Vadose Zone at the A-014 Outfall of A/M Area (U)}

December 31, 1999

Dennis G. Jackson

W. Keith Hyde

Joseph Rossabi

Brian D. Riha

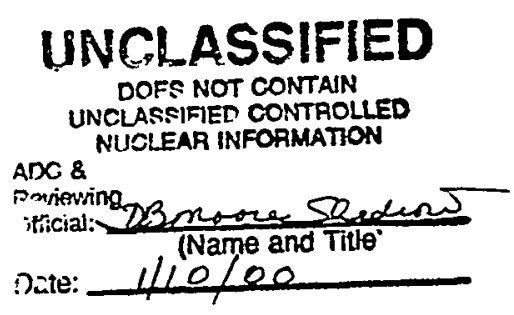

Westinghouse Savannah River Company

Savannah River Site

Aiken, South Carolina 29808

Prepared for the United States Department of Energy under Contract No.DE-AC09-96SR18500 


\section{DISCLAIMER}

This report was prepared as an account of work sponsored by an agency of the United States Government. Neither the United States Government nor any agency thereof, nor any of their employees, makes any warranty, express or implied, or assumes any legal liability or responsibility for the accuracy, completeness, or usefulness of any information, apparatus, product or process disclosed, or represents that its use would not infringe privately owned rights. Reference herein to any specific commercial product, process or service by trade name, trademark, manufacturer, or otherwise does not necessarily constitute or imply its endorsement, recommendation, or favoring by the United States Government or any agency thereof. The views and opinions of authors expressed herein do not necessarily state or reflect those of the United States Government or any agency thereof.

This report has been reproduced directly from the best available copy.

Available for sale to the public, in paper, from: U.S. Department of Commerce, National Technical Information Service, 5285 Port Royal Road, Springfield, VA 22161, phone: (800) 553-6847

fax: (703) 605-6900

email: orders@ntis.fedworld.gov

online ordering: http://www.ntis.gov/ordering.htm

Available electronically at http://www.doe.gov/bridge

Available for a processing fee to U.S. Department of Energy and its contractors, in paper, from: U.S. Department of Energy, Office of Scientific and Technical Information, P.O. Box 62, Oak Ridge, TN 37831-0062, phone: (865) 576-8401

fax: (865) 576-5728

email: reports@adonis.osti.gov 
Characterization Activities to Determine the Extent of DNAPL in the Vadose Zone at the A-014 Outfall of A/M Area (U)

December 31, 1999

Dennis G. Jackson

W. Keith Hyde

Joseph Rossabi

Brian D. Riha

Environmental Sciences and Technology Department

Savannah River Technology Center

Authentication:

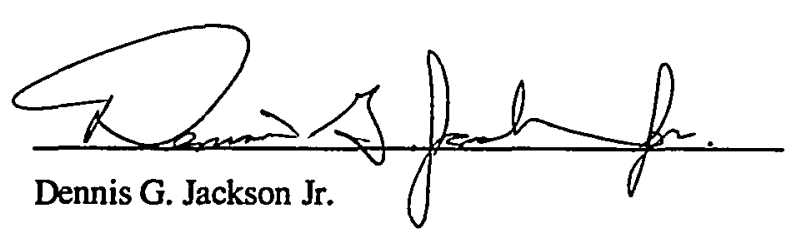

Westinghouse Savannah River Company

Savannah River Site

Aiken, South Carolina 29808

Prepared for the United States Department of Energy under Contract No.DE-AC09-96SR18500 


\section{Executive Summary}

Characterization activities conducted between February and April 1999 confirmed the presence of DNAPL in the shallow vadose zone ( 10 to 25 feet below land surface) near the headwaters of the A-014 Outfall. The characterization was associated with ongoing SVE operations at the outfall and was based on DNAPL specific techniques using hydrophobic membrane technologies. As measured with field instruments the soil gas concentrations in this interval ranged from $2,000 \mathrm{ppmv}$ to in excess of 5,000 ppmv for PCE. The extent and thickness of DNAPL was estimated using soil-gas analyses performed with field instrumentation followed by limited GC/MS confirmation. The results from the field survey were used to direct the deployment of additional extraction wells for the existing SVE system located in the vicinity of the A-014 Outfall, and to direct additional DNAPL specific characterization activities. Regions of soil gas greater than $1,000 \mathrm{ppmv}$ were targeted for additional extraction wells and regions with soil gas concentrations greater than 5,000 ppmv were evaluated with hydrophobic membrane technology. The results from these activities indicate that DNAPL is present along discrete horizons at depths between 10 and 25 feet near the headwaters of the outfall. Soil-gas data collected during the same period indicates that the DNAPL along this horizon is limited in the lateral extent. It is theorized that increased infiltration in this vicinity both during and after disposal has had an effect on the resulting DNAPL distribution in the shallow vadose zone near the headwaters of the outfall. The additional extraction wells were configured with short ( $\sim 10$ foot) screens that targeted regions of highest contamination found within the depth interval between 20-22 feet. The additional extraction volume from the DNAPL areas should provide an increase in the performance of the soil vapor extraction system near the outfall and should reduce the source to the groundwater. 


\section{DISCLAIMER}

Portions of this document may be illegible in electronic image products. Images are produced from the best available original document. 


\section{Table of Contents}

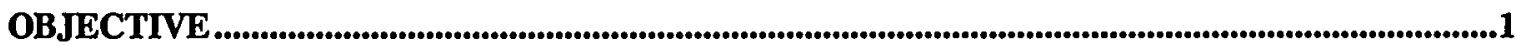

BACKGROUND

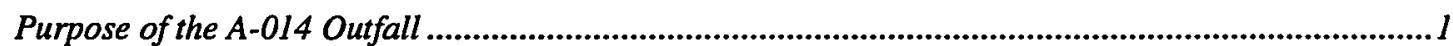

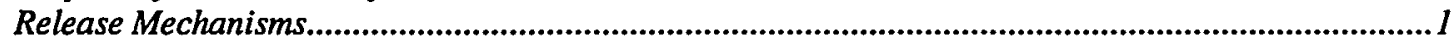

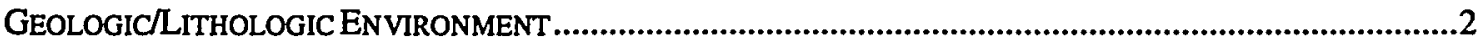

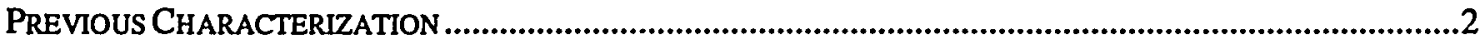

Groundwater Monitoring..........................................................................................................................2

DNAPL Characterization along the Process Sewer and at the A-014 Outfall .........................................

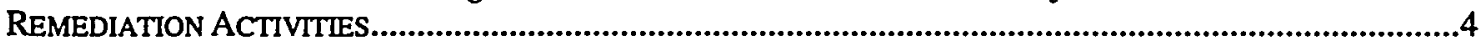

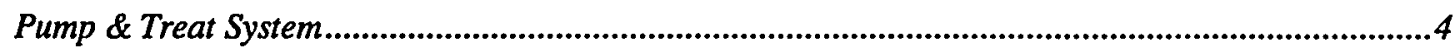

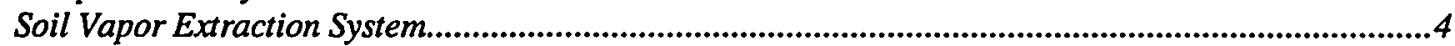

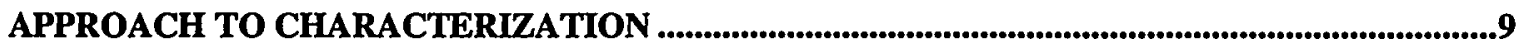

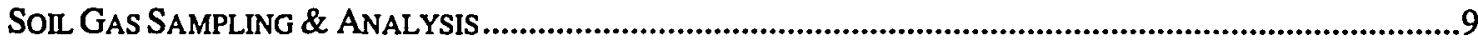

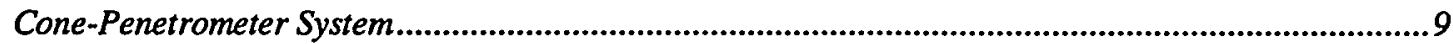

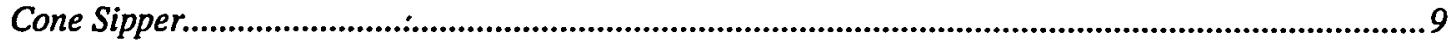

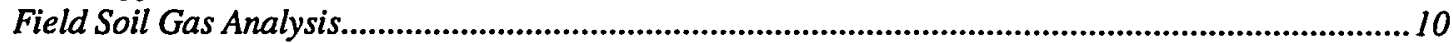

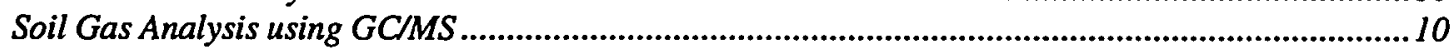

DIRECT DNAPL DETECTION WTTH RIBBON NAPL SAMPLER SYSTEM .................................................. 10

Flexible Liner Underground Technologies (FLUTe) Ltd. Membrane ................................................11

Hydrophobic Absorbent Ribbon ..................................................................................................................

Overview of Installation Method in Open BoreholeNadose Zone ......................................................11

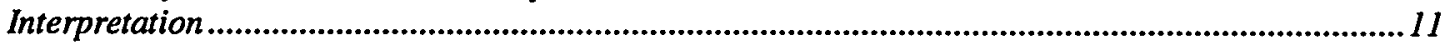

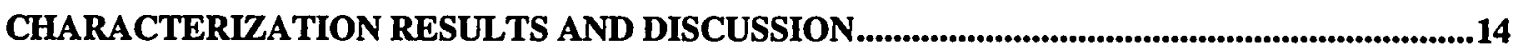

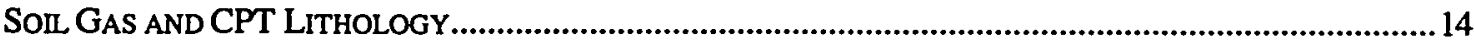

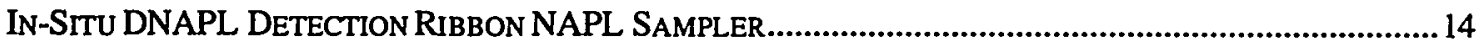

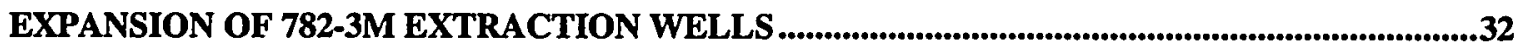

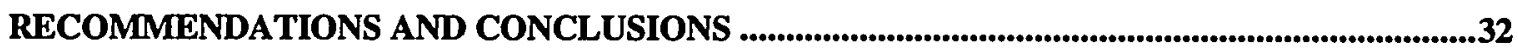

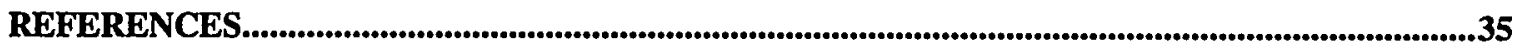

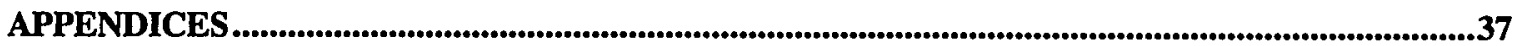




\section{List of Figures}

Figure 1: A/M Area Map Showing Principle Source Areas, Process Sewer System, M-Area BASIN, AND A-014 OUTFALL AND LOCATION OF SOIL VAPOR EXTRACTION SYSTEMS. .5

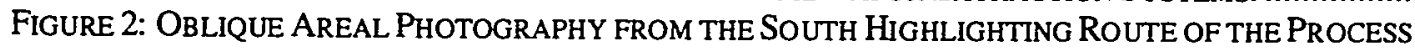
SEWER SYSTEM FROM M-AREA FACIL ITIES TO THE A-014 OUTFALl. (SEPTEMBER 10, 1984) ...............6

FIGURE 3: HISTORICAL TRICHLOROETHYLENE AND TETRACHLOROETHYLENE CONCENTRATIONS FROM RECOVERY WELL RWM-6 LOCATED AT THE A-014 OUTFALL . ............................................................

FIGURE 4: HISTORICAL TRICHLOROETHYLENE AND TETRACHLOROETHYLENE CONCENTRATIONS ASSOCIATED WTTH THE 782-3M SOLL VAPOR EXTRACTION UNIT AT THE A-014 OUTFALL....................8

FIGURE 5: (A) CONCEPTUALIZATION OF CONTACT BETWEEN THE RIBBON NAPL SAMPLER AND SUBSURFACE DNAPL IN AN OPEN BOREHOLE. (B) ILLUSTRATION OF RIBBON NAPL SAMPLER DEPLOYMENT VIA FLUTE MEMBRANE TECHNOLOGY.

FIGURE 6: DEPLOYMENT AND INTERPRETATION OF RIBBON NAPL SAMPLER AT A-014 OUTFALL. ................13

FIGURE 7: LOCATION OF CPT INVESTIGATIONS AND VADOSE ZONE WELL INSTALLATIONS AT THE A-014 OUTFALL. .16

FiguRE 8: SubSURFACE DNAPL DETECTED WITH RIBBON NAPL SAMPLER DEPLOYED AT HFM-3/MVE 17

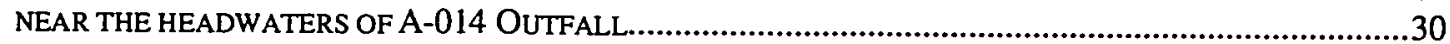

FIGURE 9: COMPARISON OF RESULTS FROM RIBBON NAPL SAMPLER DEPLOYED AT HFM-1, HFM-2, HFM3, AND MVE-17. 


\section{List of Tables}

TABLE 1: VAPOR PRESSURE AND DNAPL EQUIVALENT CONCENTRATIONS For CONSTTTUENTS MEASURED WTTH FIELD INSTRUMENTS AT HEADWATERS OF THE A-014 OUTFALL.............................................10

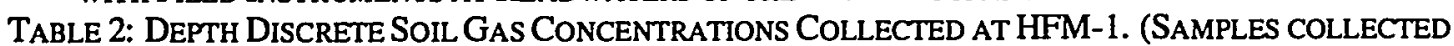

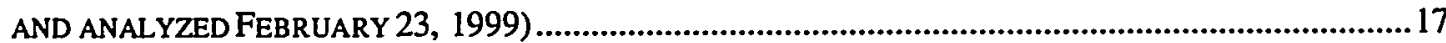

TABle 3: Depth Discrete Soll Gas ConCENTRATIONS Collected at HFM-2. (SAMPLES COllected

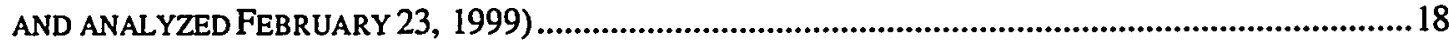

TABle 4: Depth Discrete SoIl Gas Concentrations Collected at HFM-3. (SAmples COLleCted

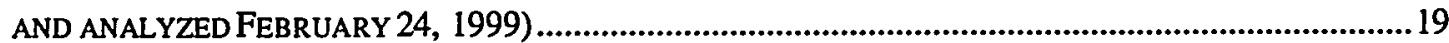

TABle 5: Soll GAS CONCENTRATIONS FROM VADOSE MONITORING PROBES MVC-2 AND MVC-3 LOCATED AT THE A-014 OUTFALL (SAMPLES COLLECTED AND ANALYZED APRIL 22, 1999)...............................20

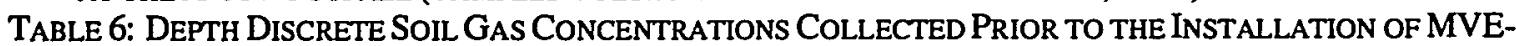

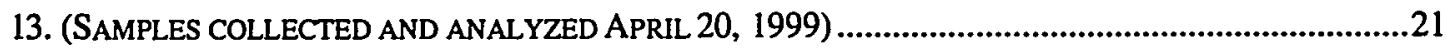

TABle 7: Depth Discrete Soll Gas Concentrations Collected PRioR to the Installation OF MVE-

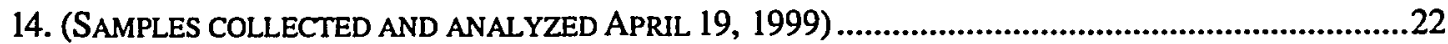

TABle 8: DePth Discrete Soll Gas Concentrations Collected Prior to the Installation OF MVE-

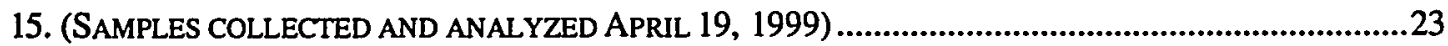

Table 9: Depth Discrete Soil Gas Concentrations Collected Prior to the Installation of MVE-

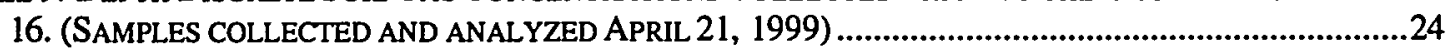

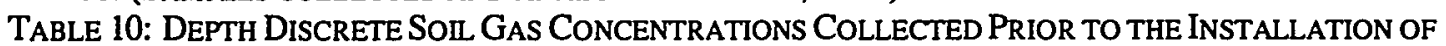

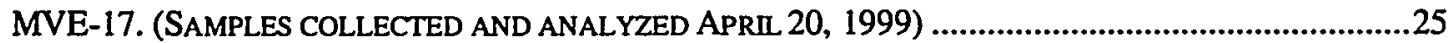

TABLE 11: DEPTH DisCRETE SOIL GAS CONCENTRATIONS COLLECTED PRIOR TO THE INSTALLATION OF MVE-18. (SAMPLES COLLECTED AND ANALYZED APRIL 19, 1999) ...................................................26

TABLE 12: DePTH DisCRETE Soll Gas Concentrations Collected Prior to the INSTALlation of

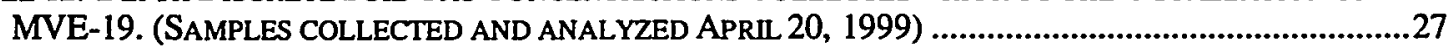

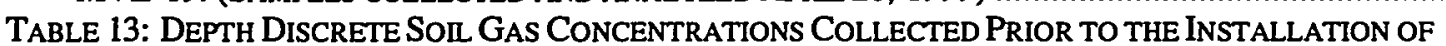

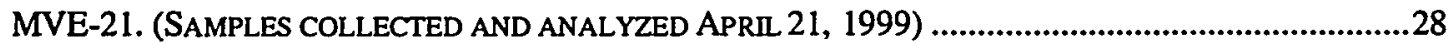

Table 14: Depth Discrete Soll Gas Concentrations Collected Prior to the Installation of

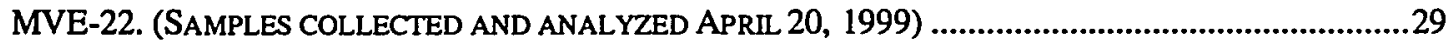

TABLE 15: CONFIRMATORY GC ANAL YSIS FOR SOIL-GAS SAMPLES COLlECTED AT THE HEADWATERS OF

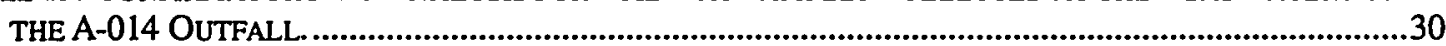

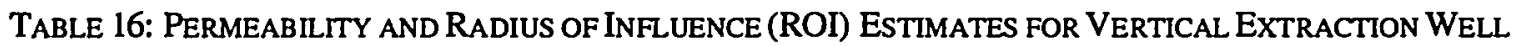
MVE-9 AT THE A014 OUTFALL. (ADOPTED FROM JAROSCH ET. AL. 1998) ............................................33

TABLE 17: SUMMARY OF INFORMATION FOR VADOSE ZONE WELLS INSTALLED AT THE A-014 OUTFALL....34 


\section{Objective}

The purpose of this investigation was to perform characterization activities necessary to confirm the presence and extent of DNAPL in the shallow vadose zone near the headwaters of the A-014 Outfall. Following the characterization, additional soil vapor extraction wells and vadose monitoring probes were installed to promote and monitor remediation activities in regions of identified DNAPL.

\section{Background}

The A/M-Area is located in the northern section of the Savannah River Site (SRS) and consists of facilities that fabricated reactor fuel and target assemblies for the SRS reactors (M-Area), laboratory facilities (SRTC, formally SRL), and administrative and support facilities (A-Area). Operations at these and other facilities within the $\mathrm{A} / \mathrm{M}$ Area resulted in the release of chlorinated solvents, primarily trichloroethylene (TCE), tetrachloroethylene (PCE) and 1,1,1-trichloroethane (1,1,1-TCA) to the subsurface (Marine and Bledsoe, 1984). These releases have resulted in the contamination of the soil and groundwater within the area. Since the discovery of dissolved solvents within the groundwater, SRS has pursued an aggressive path towards environmental remediation of the groundwater and subsurface contamination. To accomplish this, SRS has:

- Installed an extensive groundwater recovery well network to treat contaminated groundwater;

- Installed a series of soil vapor extraction units for removal of contaminants in the vadose zone;

- Deployed a series of vertical recirculation wells to address regions of downgradient migration;

- Supported the characterization of subsurface features to determine influences on groundwater flow;

- Continually supported demonstration programs for developing new, cost-effective soil and groundwater remediation technologies.

\section{Purpose of the A-014 Outfall}

Beginning in 1952, the process sewers received wastes from the $313-\mathrm{M}$ and $320-\mathrm{M}$ process facilities located in $\mathrm{M}$-Area. The process wastes from the $313-\mathrm{M}$ and $320-\mathrm{M}$ facilities were discharged into a process sewer system and released at the A-014 Outfall. This surface outfall feeds an unnamed tributary of Tims Branch, and eventually discharges to the Savannah River through Upper Three Runs Creek. Between 1952 and 1979 , historical records estimate that $1,395,000 \mathrm{lbs}$. of solvent were released to the A-014. Of this quantity, $72 \%$ was tetrachloroethylene, $27 \%$ was trichloroethylene, along with a smail quantity of $1,1,1$ tricloroethane. Visual surveys of the process sewer system performed in 1982 identified cracks and damage in the vitreous clay pipe along the routes to both the basin and the A-014 Outfall (Marine and Bledsoe, 1984). In addition to the cracks and damage identified in the 1982 survey, the process sewer line had numerous man-holes that were located approximately $110 \mathrm{~m}$ (350 ft) apart along the entire length of the system. Solvent discharge to the process sewer ended in 1979, and discharges to the M-Area Settling Basin ended in July 1985. In 1989, the portion of the process sewer line from the M-Area fence to the settling basin was excavated and removed.

\section{Release Mechanisms}

The tributary of Tims Branch, referred to as the A-014 Outfall, received chlorinated solvents in the form of process wastes from the M-Area facilities from 1952 through 1979. Beginning in 1979, the process wastes from these facilities were drummed and stored for future disposal (Christensen and Brendell, 1982). The waste streams released from these facilities traveled approximately 3250 feet through a process sewer system and discharged to a tributary of Tims Branch at the A-014 Outfall. In addition to the chlorinated solvents, the composite waste stream included acid solutions, caustics, salts, and miscellaneous lubricants used in the 300-Area process. The total mass of effluent wastes released to the A-014 has not been documented; however, inter-office correspondence (Jackson et. al. 1996) indicates that during 1969 and 1970 , approximately 618,240 pounds of industrial wastes were released to the A-014 Outfall. Of the total 
amount of effluent waste released in this period approximately $23 \%, 139,000$ pounds, was organic waste, including trichloroethylene, tetrachloroethylene, and methanol.

In addition to the co-disposed waste materials, other aspects that may have an effect on the distribution and location of chlorinated solvent in this region are the frequency and magnitudes of discharge and the large volume of wastewater used to dilute the waste stream. With respect to the total amount of organic wastes released in the 1969 to 1970 time period, 91,000 pounds were tetrachloroethylene, 12,000 pounds were trichloroethylene, and the remaining 36,000 pounds were methanol. The tetrachloroethylene and methanol were released in batch once and twice per week, respectively, in quantities estimated at 1750 pounds of tetrachloroethylene per release and 350 pounds of methanol per release. (Appendix B; Jackson et. al. 1996) Based on the available historical records, the 12,000 pounds of trichloroethylene was released as a one time event which was most likely associated with the degreasers located in 320-M. If these release mechanisms are representative of the typical historical release schedules for trichloroethylene and tetrachloroethylene, the resulting subsurface distributions of trichloroethylene and tetrachloroethylene could be dramatically different.

\section{Geologic/Lithologic Environment}

The vadose zone beneath $\mathrm{A} / \mathrm{M}$ Area contains several clay layers of local hydrologic significance. The individual clay layers within these intervals are neither exceptionally thick nor laterally extensive, but are considered a significant factor in controlling movement of DNAPL through the vadose zone. Recent characterization and basline mapping studies (Parker et.al. 1999) have focused on the interbedded layers of sand, silt, and clay, of the vadose zone in A/M Area.

Eddy and others, (1991) delineated four of these intervals which they referred to as "semiconfining/confining zones" beneath the integrated demonstration site. These intervals include the "200-foot clay", "270-foot clay", "300-foot clay" and the " 325 -foot clay". The intervals are informally named by the approximate elevations of their upper boundaries. The "200-foot clay" of Eddy and others (1991) is equivalent to the "Green Clay" confining zone of the Steed Pond aquifer later delineated by Aadland and others (1995).

Each of these intervals represents a discrete depositional sequence. During the current study, it was realized that an additional interval, the "230-foot clay", should be added to the four intervals identified by Eddy and others (1991). This interval was identified by Jackson and others (1996) as containing a clay layer that has a profound influence on DNAPL migration below $\mathrm{A} / \mathrm{M}$-Area. In previous reports, this interval has been included as a lower layer within the " 270 -foot clay".

The "200-foot clay" as described by Eddy and others (1991) is relatively continuous across the study area. It becomes thin in the northern part of the study area and often contains trace amounts of glauconitie in the southern part of the study area.

The "230-foot clay" commonly rests near the water table and extends down into the water table where the clay is thick. Its distribution is sporadic and the thickness varies between zero to 41 feet. The clay is typically light yellowish green to yellowish orange with interbedded fine sand. Cores taken from within this interval commonly contain sponge spicules and evidence of silica replacement. This interval contains sporadically distributed interbeds of fine shell material. The clay within this interval is important because it is the last layer in the vadose zone preventing DNAPL from reaching the MAAZ. A thick clay layer is present in some cores and is often interbedded with silica-cemented sand. The " 270 -foot clay" is roughly equivalent to the "tan clay" confining zone as defined in the General Separations Area (GSA) by Aadland and others (1995). The " 325 -foot clay" consists of multiple layers of sand and clay and is typically dark purple to light grayish purple in color.

\section{Previous Characterization}

\section{Groundwater Monitoring}

Previous studies incorporated indirect techniques to determine the extent of DNAPL present at the A-014 Outfall (Jackson et. al. 1996). In this investigation the lateral presence of DNAPL throughout the A/M Area 
was inferred from historical groundwater concentrations. The approach examines concentration data with respect to pure-phase solubility limits and is typically incorporated during site characterization as an indicator of DNAPL (Cohen and Mercer, 1993) (Pankow and Cherry, 1996). These techniques infer the presence of DNAPL based upon chemical analysis of groundwater, soil, and soil-vapor. The identification and extent of DNAPL presence other than by direct measurement is subjective and dependent upon a variety of geological, chemical, and site specific variables.

As presented (Jackson et. al. 1996) previous investigations identified historical concentrations in excess of the $10 \%$ criteria were identified at monitoring wells MSB 31B, MSB 31C, and MSB 31CC. As presented in this study the aqueous concentrations from monitoring well MSB 31C are consistently reported in the 30 to $60 \%$ range of pure-phase solubility for both trichloroethylene and tetrachloroethylene and have been reported in excess of solubility limit for tetrachloroethylene on numerous occasions. Monitoring well MSB $31 \mathrm{C}$ is screened in the M-Area aquifer zone across the "230-Foot Clay". Although the Phase I DNAPL characterization activities did not detect DNAPL at this location (Looney et al., 1992), the historical data review suggests that a significant amount of DNAPL is present within the effective zone of the monitoring well.

\section{DNAPL Characterization along the Process Sewer and at the A-014 Outfall}

Drilling activities were conducted in FY97 and early FY98 in the A/M Area to further identify areas of pure phase DNAPL below the water table (Jerome et.al. 1998). The purpose of the work was to further understand the subsurface contaminant distribution and to identify locations below the water table where aggressive DNAPL remediation technologies should be pursued. This work consisted of using rotosonic drilling to complete 13 borings to either the top of the Green Clay or the top of the Crouch Branch Confining Unit. Results from these drilling activities did not support the implementation of an aggressive groundwater remediation technology. Data collected at the A-014 outfall suggested two things: 1) the soil vapor extraction units are effectively remediating the vadose zone and 2) contaminants are being transported along the middle clay of the water table aquifer and then penetrate deeper into water bearing zones.

Three cores, MRS 11, 14, and 18, were collected near the A-014 Outfall. This surface outfall received solvent wastes from 1952 through 1980 (Marine and Bledsoe, 1984). The characterization data indicated that significant contaminated intervals (ranging from $5 \mu \mathrm{g} / \mathrm{g}$ to $10 \mu \mathrm{g} / \mathrm{g}$ of PCE) are located at an elevation of approximately 220 feet msl at borings MRS 14 and 18, located adjacent to the outfall and to the west of D-Road . Contamination in this interval is controlled by clay and clay/sandy clay intervals with gravel. TCE was found at an elevation of 215 feet msl at a concentration of $5 \mu \mathrm{g} / \mathrm{g}$ in a sandy clay in boring MRS 11 which is east of the A-014 outfall. Approximately 95\% of the MRS 11 samples contained less than 0.3 $\mu \mathrm{g} / \mathrm{g}$ of PCE with the highest concentration at $1.3 \mu \mathrm{g} / \mathrm{g}$.

Importantly, this core contained higher levels of TCE than PCE. Thus, the data suggest that contaminant movement was downward through the vadose zone, with accumulation and lateral migration on top of clay lenses in the middle of the water table aquifer. Lateral migration in this interval was observed to the west, across D-Road. The TCE dominated contaminant profile in MRS 11 is indicative of earlier releases. The peak contamination in this location is deeper indicating that contaminants are penetrating the middle water table aquifer clay and the Green Clay confining zone and migrating to this location (east of the A-014 Outfall).

The data from MRS 11,14, and 18 suggest that a significant quantity of the residual contaminant is present below the water table near the A-014 outfall. Concentrations in the vadose zone (especially at an of elevation 290 feet and in the deep vadose zone below an elevation of 240 feet) were lower than the values measured in 1990 (CH2M Hill, 1990). This "reduction" may indicate clean-up by operation of the full scale SVE system, as well as heterogeneity in the system. The presence of relatively thin intervals (approximately $10 \mathrm{ft}$ thick) of elevated PCE concentrations below the water table indicate that DNAPL accumulation areas in the vicinity are probable. The concentrations measured in these cores, however, do not indicate sufficient DNAPL quantities in these particular locations to justify targeted DNAPL specific remediation activities (Jerome, 1997). 


\section{Remediation Activities}

\section{Pump \& Treat System}

With the discovery of chlorinated solvents within the subsurface below the M-Area settling basin, a pilot air stripper was installed in 1983 with a full-scale remediation program in-place by 1985 (M1 System). The M1 system consists of eleven operating recovery wells, RWM-1 through 11, and provides groundwater remediation via pump and treat for the central A/M Area. The central A/M Area is defined based upon zone of capture modeling for this system and its effectiveness has been evaluated through extensive groundwater modeling activities. (Papadopulos \& Associates 1987, Haselow et.al 1991)

Previous modeling activities evaluated the effectiveness of the pump \& treat system (Jackson and Aleman, 1995) with regards to remediation goals in the Tertiary sediments. The previous investigation identified the 5,15 , and 30 year zone of capture in the "Middle Sand" aquifer zone, the Lost Lake aquifer zone, and in the M-Area aquifer zone.

\section{Soil Vapor Extraction System}

Soil vapor extraction technologies are being used to facilitate the remediation of chlorinated solvents in the subsurface of the A/M Area at the Savannah River Site. Soil vapor extraction has been deployed in numerous stages to enhance the performance of the ongoing RCRA A/M Area Corrective Action Program. The overall objective of the Corrective Action Program is to provide cost effective remediation of contaminated soil and groundwater beneath the A/M Area of the Savannah River Site. The foundation of this program is a groundwater pump \& treat system that has been in operation since 1985. Along with the continued operation of this system, SRS has continually evaluated, developed, and deployed new technologies to improve the performance and cost effectiveness of the overall program.

The first enhancement to this system, soil vapor extraction, has been installed in stages between 1987 and 1995. The soil vapor extraction system was installed as a cost-effective supplement to the existing groundwater pump \& treat system. SVE significantly increased mass removal and improved the overall remediation performance. As SVE operations removed the residual DNAPL from the inter-bedded sands, silts, and clays of the vadose zone, the production of these systems decreased. To evaluate these decreases, SRS utilizes traditional and innovative characterization technologies. These results are then used enhance the performance of the system and/or select an alternate remediation technology. 


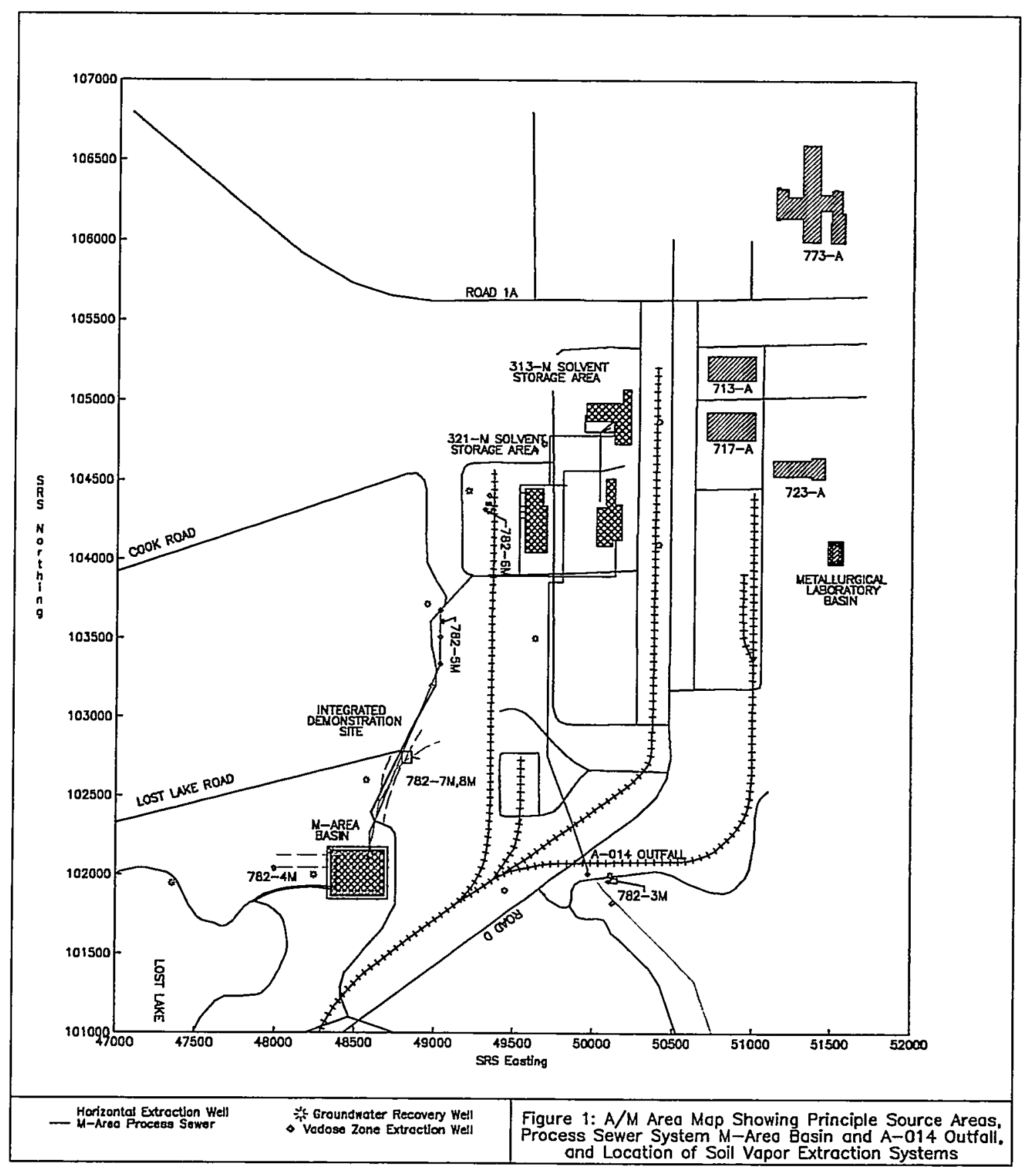

Figure 1: A/M Area Map Showing Principle Source Areas, Process Sewer System, M-Area Basin, and A-014 Outfall and Location of Soil Vapor Extraction Systems. 


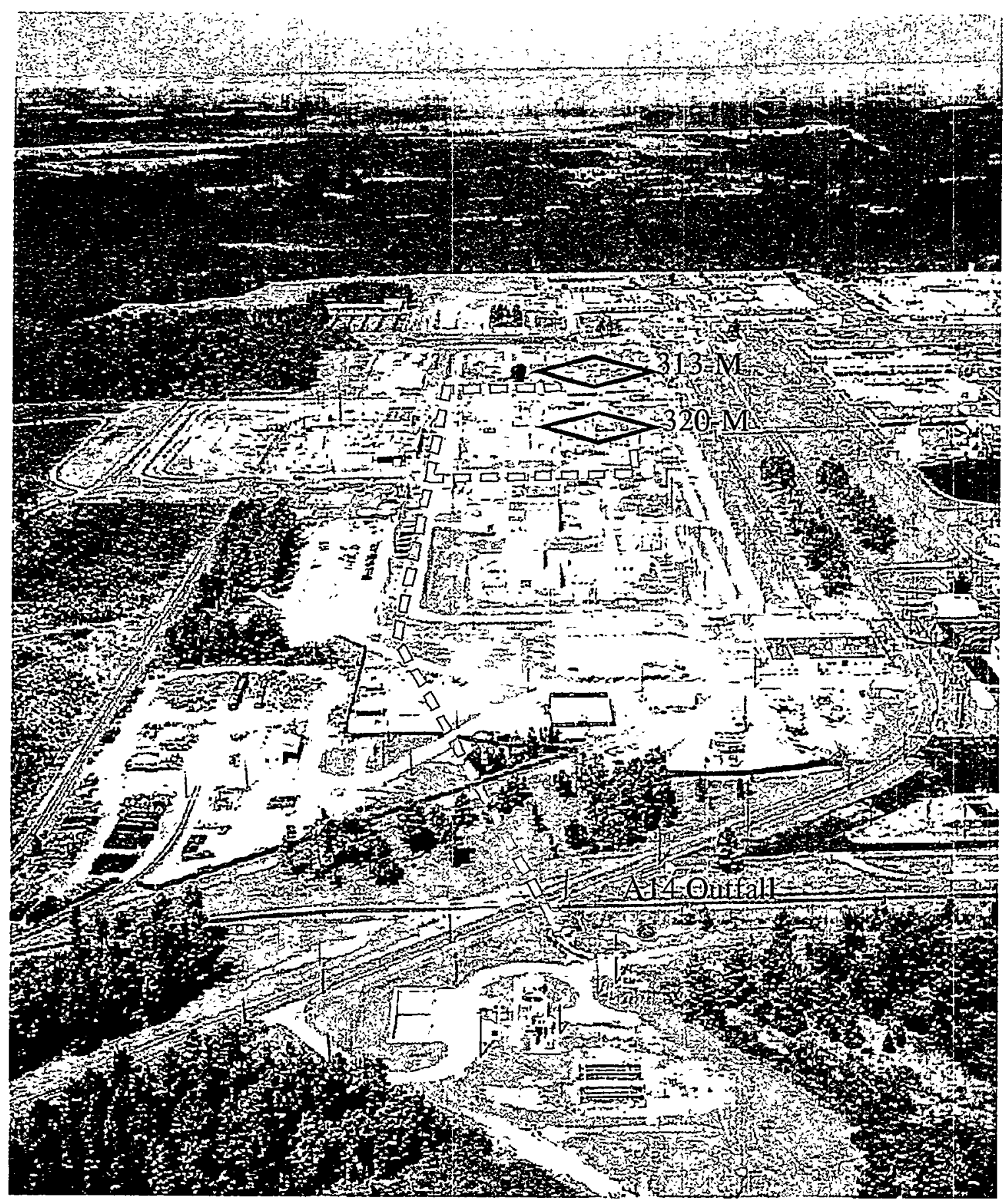

Figure 2: Oblique Areal Photography from the South Highlighting Route of the Process Sewer System from M-Area Facilities to the A-014 Outfall. (September 10, 1984) 

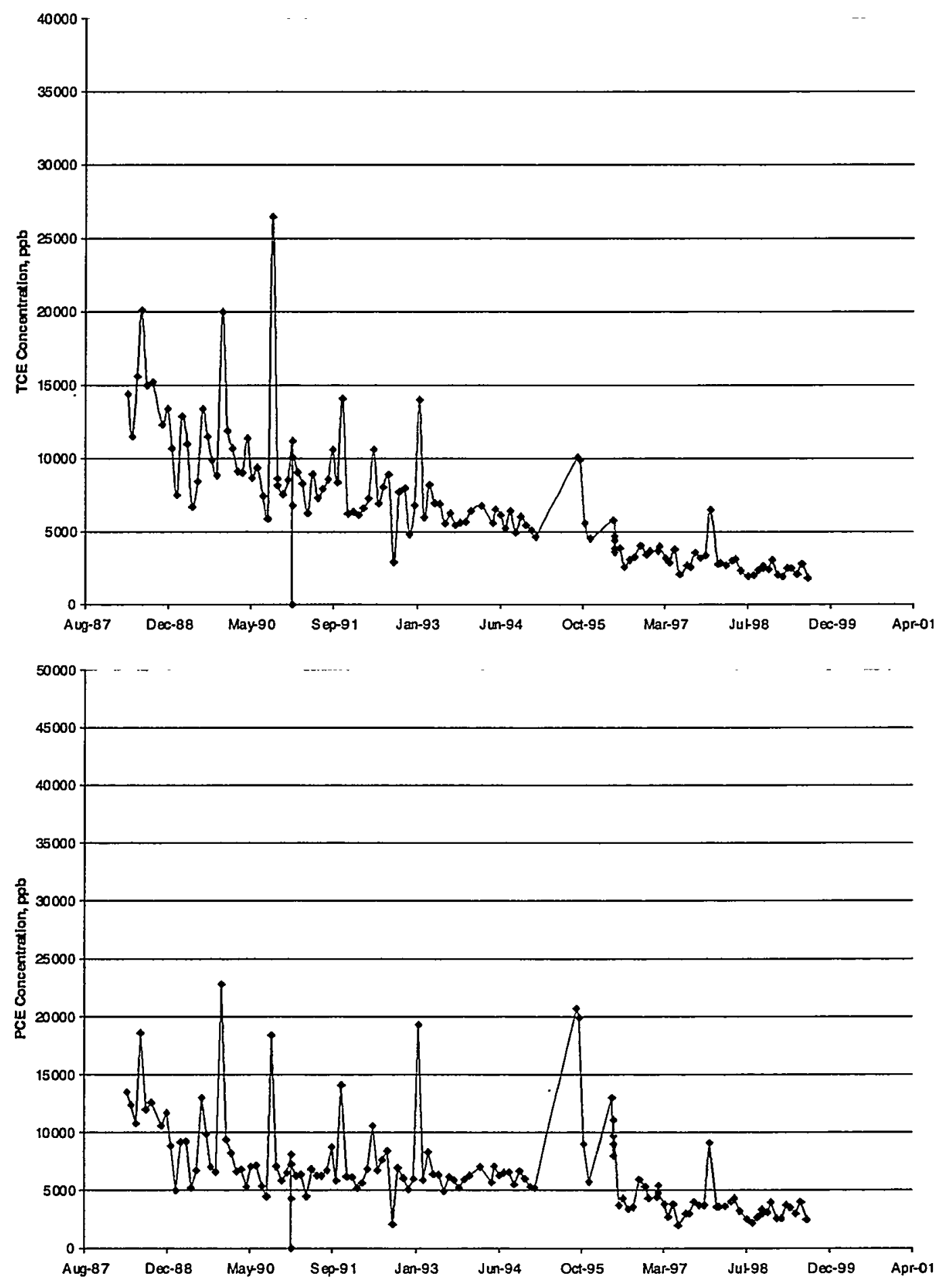

Figure 3: Historical Trichloroethylene and Tetrachloroethylene Concentrations from Recovery Well RWM-6 located at the A-014 Outfall. 
HIstorical Concentrations for SVE Unit 782-3M Located at the A-014 Outfall

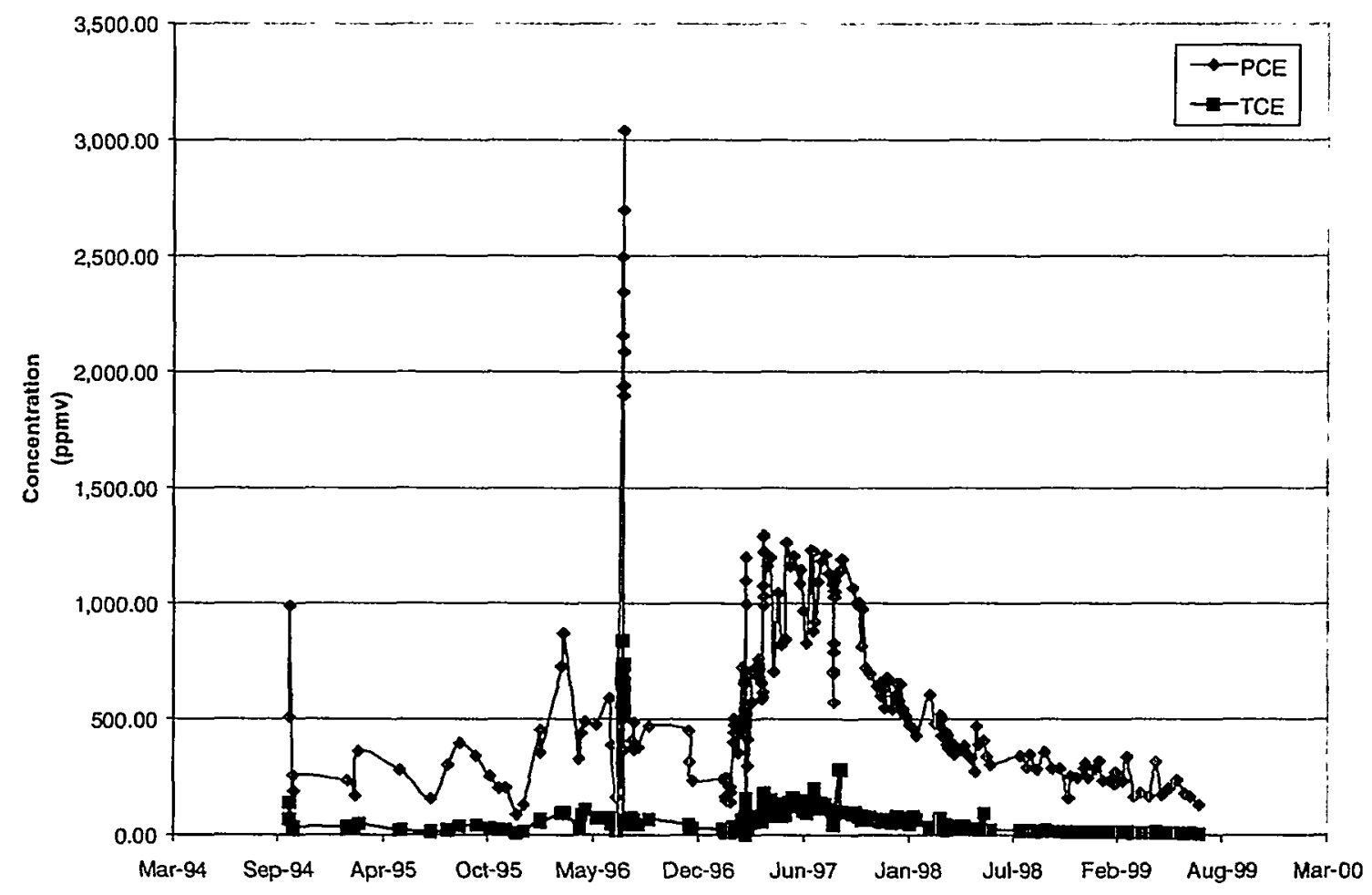

Figure 4: Historical Trichloroethylene and Tetrachloroethylene Concentrations Associated with the 782-3M Soil Vapor Extraction Unit at the A-014 Outfall. 


\section{Approach to Characterization}

A dynamic approach to characterization was used to determine the extent of DNAPL near the headwaters of the A-104 Outfall. The characterization approach used cone-penetrometer based technologies to evaluate the extent of high soil-gas concentration, determine the presence of subsurface DNAPL, and install vadose zone monitoring and/or extraction wells as appropriate. In this approach, initial depth-discrete, conepenetrometer based soil gas surveys were performed with soil gas concentrations determined using field instruments with select GC/MS confirmation. Regions of soil gas concentrations that were high relative to the vapor pressure were considered to be associated with the presence of nearby DNAPL. These regions were further investigated using in-situ DNAPL detecting methods. Upon completion of characterization activities, boreholes were completed as either a extraction wells for later connection to the 782-3M SVE system or as additional vadose monitoring probes.

\section{Soil Gas Sampling \& Analysis}

Depth-discrete soil-gas sampling was performed using a cone-penetrometer based soil-gas sampling system. This approach allows for the acquisition of geologic data and soil-gas samples as a function of depth in a single CPT push. The system used to characterize the headwaters of the A-014 Outfall consisted of cone-penetrometer system configured to infer geologic information from the following parameters: sleeve stress, tip stress, pore pressure, and resistivity. Along with these sensors, the cone-penetrometer was also equipped with a gas sampling device that allows for the collection and analysis of soil-gas samples from multiple intervals. Samples are brought to the surface using a vacuum pump that has wetted parts made of teflon materials. The soil-gas collection system is directed either to surface instrumentation for field gas analysis or connected to a Tedlar Bag for later analysis via GC/MS. Additional information on these components is provided in the following discussions. In this characterization approach, soil-gas samples are typically collected on 5 to 10 foot intervals and at major lithologic changes.

\section{Cone-Penetrometer System}

The cone penetrometer is a heavy-weight truck (17 tons) with a hydraulic push system that is used for subsurface site characterization. In the standard configuration, the tip of the cone penetrometer rod is equipped with sensors that measure depth-discrete physical and geologic parameters of the subsurface. Detection instruments and sampling devices for water, gas, and soil have been modified and housed within the cone penetrometer rods to provide detailed contaminant information. CPT technology expedites site characterization and significantly reduces the cost of characterization of contaminated sites and the amount of investigative-derived waste (IDW). Measurements are made in situ which often eliminates the need for sample extraction and significantly reduces the amount of contaminated waste. In situ sampling and analysis also reduces the need for costly laboratory analysis and subsequent risks of sample contamination or alteration. Data is gathered in "real-time" that strengthens and expands decision-making capabilities in the field. Samples can be taken at smaller scale depth intervals with more certainty than with traditional methods such as drilling.

\section{Cone Sipper}

The Cone Sipper is a groundwater and soil vapor sampling device designed to be used with a cone penetrometer truck (CPT). The probe is advanced into the subsurface with the CPT and is used to collect samples at multiple depths in a single borehole while collecting CPT lithology data. Samples are brought to the surface via small-diameter tubes and the device can be purged for reuse in situ by injecting distilled water, air, or inert gas. The main advantage of the Cone Sipper over other groundwater samplers is that it eliminates the need for retrieval and decontamination of the sampler between sampling intervals. The simple construction ensures reliable operation. 


\section{Field Soil Gas Analysis}

The Bruel \& Kjaer Model 1302 is a device equipped with an infrared photo-acoustic spectrometer capable of measuring five separate gases simultaneously. For this work the instrument was configured to measure tetrachloethylene, trichloroethylene, carbon tetrachloride, carbon dioxide, and water vapor. Other than the water vapor that is measured as the dew point temperature, all of the soil-gas parameters are measured in volume of constituent per volume of soil gas (ppmv). The photo-acoustic spectrometer uses the unique spectral properties of the contaminants to quantify concentration. After a sample is drawn into the analysis chamber, the gas is irradiated with a pulsed mid-infrared band of light specified by a particular bandpass filter (the target component's principle absorption band). The pulsed light produces pressure waves in the chamber which are measured by sensitive microphones. Higher acoustic wave amplitudes correspond to higher concentrations. Table 1 presents the vapor pressure and gaseous concentrations in equilibrium for the volatile compounds which were measured at the headwaters of the A-014 Outfall. The equivalent concentrations presented are used as indicators with the field results from the B\&K. Those intervals with soil-gas concentrations approaching these levels are highly likely to contain DNAPL.

Table 1: Vapor Pressure and DNAPL Equivalent Concentrations for Constituents Measured with Field Instruments at Headwaters of the A-014 Outfall.

\begin{tabular}{|r|r|r|r|}
\hline Constituent & $\begin{array}{c}\text { Molecular } \\
\text { Weight }\end{array}$ & $\begin{array}{c}\text { Vapor Pressure } \\
\text { @ } \text { 25 }^{\circ} \mathrm{C} \\
\text { (mm Hg torr) }\end{array}$ & $\begin{array}{c}\text { Equivalent } \\
\text { Concentration } \\
\text { (ppmv) }\end{array}$ \\
\hline Carbon Tetrachloride & 153.8 & 90.0 & $\sim 118,400$ \\
\hline Trichloroethylene & 131.5 & 57.8 & $\sim 76,000$ \\
\hline Tetrachloroethylene & 165.8 & 14.0 & $\sim 18,500$ \\
\hline
\end{tabular}

\section{Soil Gas Analysis using GC/MS}

The field instruments used as the basis for characterization are subject to interference's from other compounds such as Freon-11 and Freon-113 and have non-linear responses in regions at or near the vapor pressure concentration. To account for possible interference and to confirm intervals of high soil gas concentration, the results from the field instruments are typically confirmed using an alternate analytical technique such as GC/MS. Confirmation sampling involves collection of soil-gas samples in Tedlar bags. After collection the samples are stored away from light at constant temperature and analyzed within 24 hours of sampling to avoid sample loss or degradation. Each sample is analyzed on a HP 5890 Series II with electron capture (ECD) and flame ionization detectors (FID) in parallel or an SRI 8610 gas chromatograph $(G C)$ using direct injection. The $G C$ is calibrated using certified gas standards containing the compounds of interest (cis-DCE, $\mathrm{CCl}_{4}$, Freon-11, $\mathrm{CHCl}_{3}$, Freon-113, Freon-12, PCE, TCA, TCE, and Vinyl Chloride) at typical concentrations of $1,10,100,500$, and 1000 ppmv and laboratory air blanks.

\section{Direct DNAPL Detection with Ribbon NAPL Sampler System}

The Ribbon NAPL Sampler (RNS) is a direct sampling device that can provide detailed depth discrete mapping of Non Aqueous Phase Liquids (NAPLs - liquid solvents and/or petroleum products) in a borehole. This NAPL characterization technique uses the Flexible Liner Underground Technologies, Ltd. (FLUTe) membrane system (patent pending) to deploy a hydrophobic absorbent ribbon in the subsurface. The system is pressurized against the wall of the borehole and the ribbon absorbs the NAPL that is in contact with it. A hydrophobic dye (Sudan IV), which is sensitive only to NAPL, is impregnated in the ribbon and turns it bright red when the contaminants are contacted. The membrane is retrieved with a tether connected to the bottom of the membrane by turning the liner inside out. At the surface, the liner is inverted and the ribbon is removed and examined. The presence and depth discrete location and nature of DNAPL is indicated by brilliant red marks on the ribbon. Sections of ribbon can be sent for laboratory analysis to identify the specific NAPL compounds present. The Ribbon NAPL Sampler can be deployed with Cone Penetrometer (CPT) or traditional drilling methods in both the vadose and saturated zones. Figure 5(a) presents a schematic representation of a borehole with the flexible membrane deployed with the hydrophobic absorbent ribbon. 


\section{Flexible Liner Underground Technologies (FLUTe) Ltd. Membrane}

The FLUTe membrane consists of an airtight membrane liner that is pneumatically and/or hydraulically installed in a borehole. The rugged flexible tubular membrane supports and seals the borehole wall and can be installed in the saturated and vadose zones by several techniques. The membrane technology has been used to place sampling ports and sensors in varying sized boreholes to depths of $800 \mathrm{ft}$. Removal of the membrane is accomplished by turning the membrane inside out by pulling on a tether connected at the bottom of the liner. The membrane can be reused for multiple deployments.

\section{Hydrophobic Absorbent Ribbon}

The absorbent ribbon is a sleeve/sheath that covers the FLUTe membrane and is manufactured from a material that will repel water and absorb liquid solvents and petroleum products (NAPLs). This hydrophobic material readily "wicks" LNAPL and DNAPL compounds from the adjacent borehole sediments. The primary analysis method uses a hydrophobic ribbon impregnated with a powdered oil dye (Sudan IV). The dye dissolves in NAPLs that are absorbed into the ribbon and stains the ribbon bright red. The ribbon is replaceable for additional deployments with the same FLUTe membrane.

\section{Overview of Installation Method in Open Borehole/Vadose Zone}

In non-collapsing vadose zone boreholes, the Ribbon NAPL Sampler is deployed with air pressure. The hydrophobic ribbon is attached to the membrane and the membrane is everted (turned inside out) from the canister. This eversion method prevents the ribbon from sliding along the borehole and smearing the NAPL on the membrane. The membrane is retrieved and then re-everted at the surface and inspected for the presence of NAPL. The reusable membrane is available in custom lengths and can use any length of the replaceable hydrophobic ribbon. A two-inch diameter membrane is used in CPT boreholes and other diameters are available. Figure 5(b) presents a schematic representation of the deployment of the Ribbon NAPL Sampler using the FLUTe membrane.

\section{Interpretation}

Once the Ribbon NAPL Sampler is deployed into the subsurface and exposed to NAPL, a significant red colored staining occurs on the ribbon. The size and shape of the stains are variable and dependent on the length of time the RNS remains in the borehole and the quantity and distribution of the NAPL in the formation. NAPL stains are generally bright red and have rounded edges consistent with the bleeding or wicking action of the dyed NAPL in the hydrophobic material and are apparent on both sides of the ribbon. The unexposed Ribbon NAPL Sampler has a slight pink tint which is common and should not be confused with the presence of NAPL. Handling and storage of the ribbon material often results in the concentration of the dye in areas where the ribbon is folded or handled. These generally appear as faint red lines or as finger smudges and do not have the rounded edges or brightness of the NAPL stains and are not apparent on both sides of the ribbon. Figure 6 presents the deployment and interpretation of the Ribbon NAPL Sampler after deployment. 


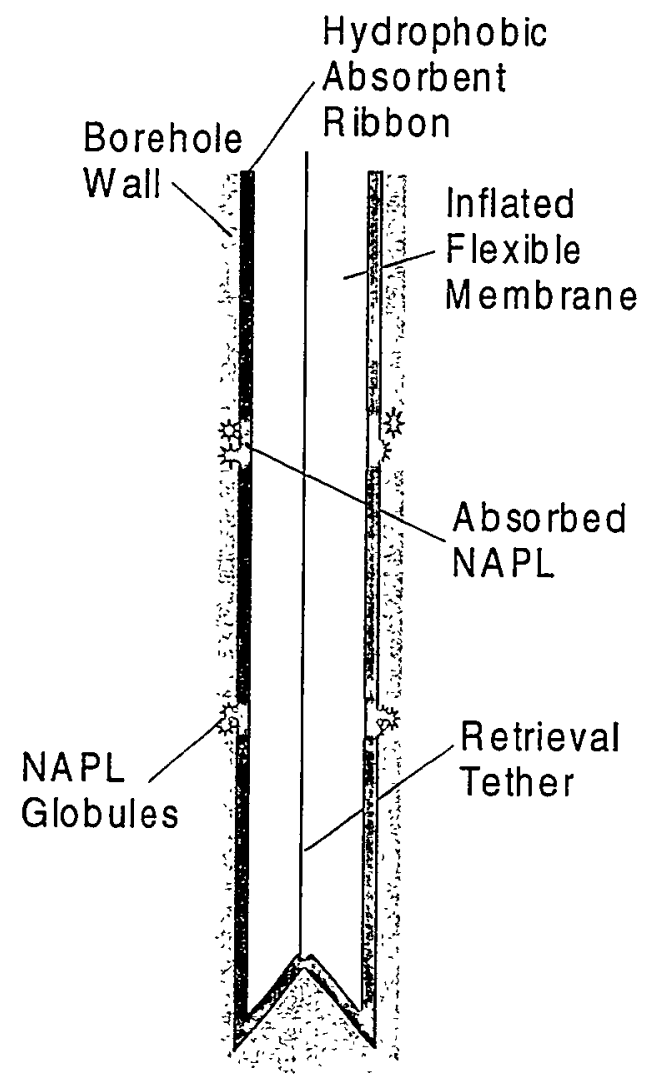

(a)

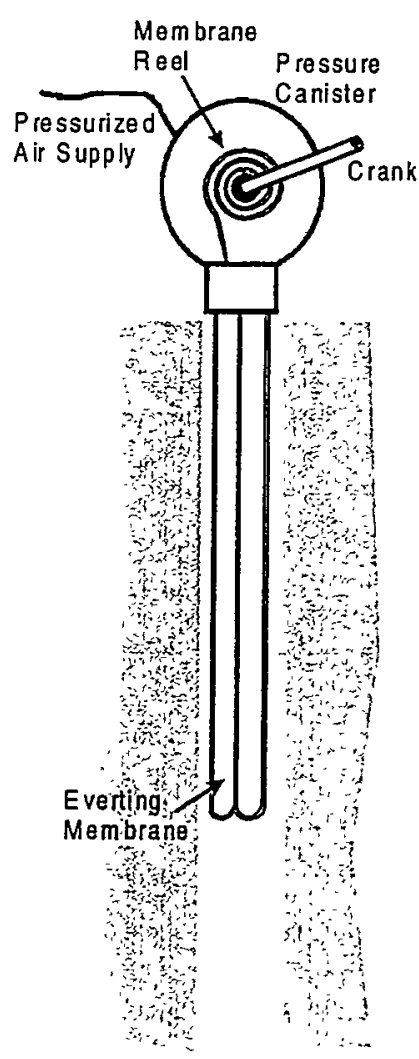

(b)

Figure 5: (a) Conceptualization of Contact Between the Ribbon NAPL Sampler and subsurface DNAPL in an open borehole. (b) Illustration of Ribbon NAPL Sampler Deployment via FLUTe Membrane Technology. 


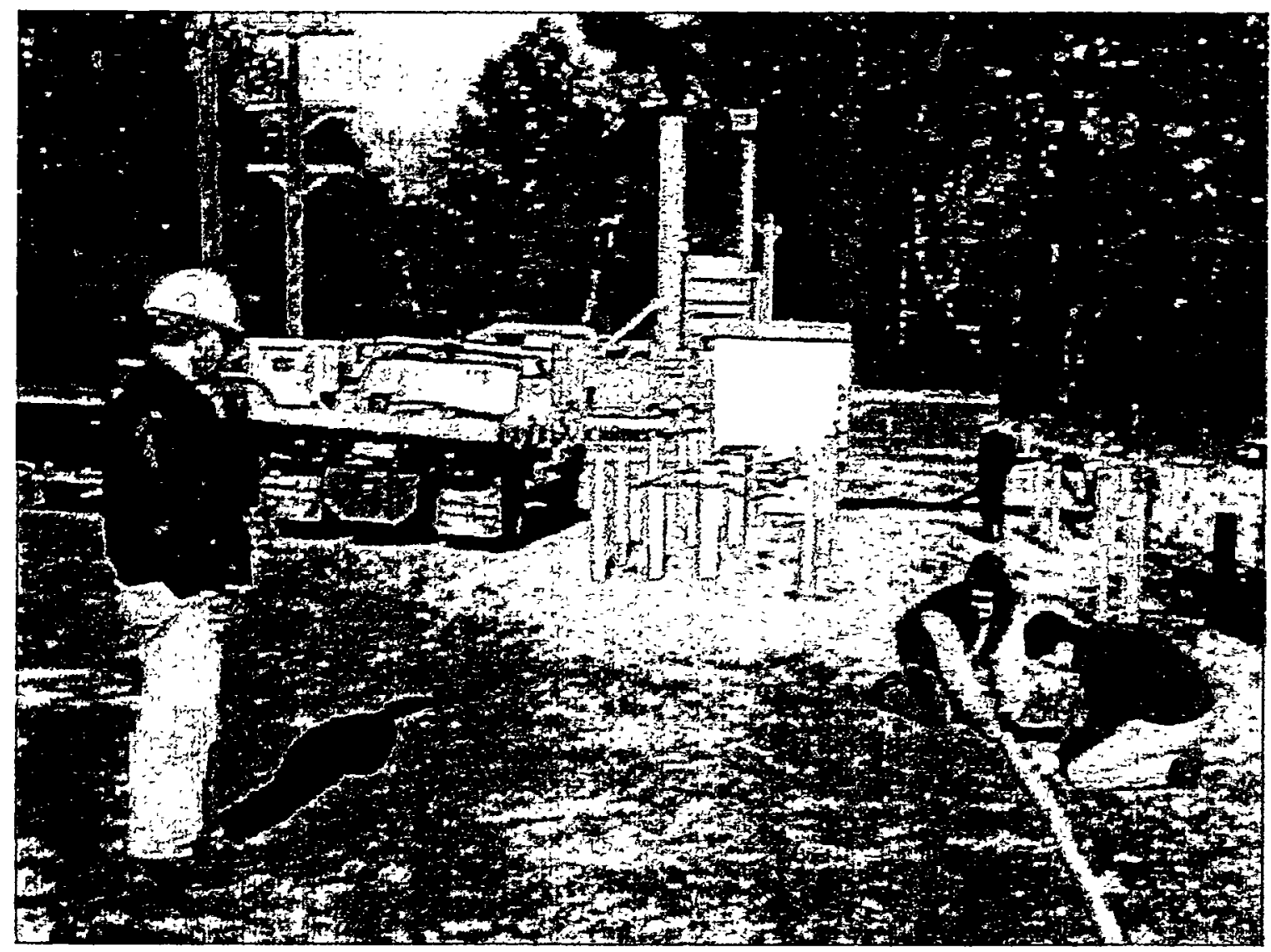

Figure 6: Deployment and Interpretation of Ribbon NAPL sampler at A-014 Outfall. 


\section{Characterization Results and Discussion}

\section{Soil Gas and CPT Lithology}

In February of 1999, initial cone-penetrometer based soil-gas investigations were performed near the headwaters of the A-014 outfall. During this characterization activity depth-discrete soil-gas concentrations were collected at three locations. The locations of these investigations are presented in

Figure 7 as HFM-1, HFM-2, and HFM-3. The soil-gas results from this activity are presented in Tables 2 through 5. As presented in Table 2 measured concentrations at HFM-1 are relatively low with the highest concentrations, $30-50$ ppmv PCE, observed in the 55-60 foot interval. The location is within 15 feet of the existing soil-vapor extraction well MVE-4. MVE-4 was installed in 1990 during the Phase I vadose zone characterization activities and has a screened interval between 293.9 and 232.5 feet mean sea level. The low soil-gas concentrations observed at HFM-1 are considered to be associated with the operation and remediation associated with well MVE-4. Tables 3 and 4 present the soil-gas results from locations HFM-2 and HFM-3, respectively. As shown in

Figure 7 these two locations are located along the current-day discharge of the A-014 Outfall on either side of the access road. As presented in Tables 3 and 4, the maximum soil-gas concentrations are two- to three orders of magnitude higher than those observed at HFM-1, and those regions of the highest concentration are located in the shallower intervals, 20 to 30 feet below land surface. The high soil-gas concentrations for PCE observed at the 25 foot, 30 foot, and 60 foot depths at HFM-2 and at the 20 and 25 foot depths in HFM-3 suggest the nearby presence of DNAPL at these locations. As indicated by the cone-penetrometer lithologic data collected at these locations (Appendix A), these intervals correspond to the upper boundaries of the finer grained materials.

In order to determine the extent of shallow contamination additional soil-gas characterization and sampling was performed in April of 1999 at additional locations near the headwaters of the A-014 Outfall. The high soil-gas concentrations observed in the shallow vadose zone at HFM-2 and HFM-3 were confirmed at this time and soil-gas samples were collected and analyzed from vadose monitoring probes MVC-2 and MVC3. The locations of these investigations, identified as MVE-13 through 22, are presented in Figure 7 as well as the location of the vadose zone monitoring probes MVC-2 and MVC-3. Locations MVE-13 through MVE-22 were selected to provide information on a relatively fine scale with locations positioned at less than 50 foot intervals. Two transects on 50 foot intervals were located perpendicular to the outfall near the headwaters. This series of characterization points was deployed to determine the lateral spreading of DNAPL away from what is considered to be the primary release point in this vicinity. An additional transect was located on the southwest side of the discharge reach to access potential migration along the discharge reach. Although planned for investigation, soil-gas sampling was not performed at location MVE-20 due to possible erosion and undercutting from the nearby outfall. Soil-gas results from these characterization activities are presented in Tables 5 through 14 with the results from confirmatory data analysis using gas chromatography presented in Table 15. Cone-penetrometer lithologic data collected at locations MVE-13, MVE-14, MVE-15, MVE-16, MVE-17, MVE-18, MVE-19, MVE-21, and MVE-22 is presented in Appendix A.

\section{In-Situ DNAPL Detection Ribbon NAPL Sampler}

Based on the vapor concentrations presented in Table 1 for PCE, the soil-gas concentrations observed in the shallow vadose zone at locations HFM-2 (Table 2) and HFM-3 (Table 4) indicated that DNAPL might be present at these locations. The presence of DNAPL was confirmed at these two locations using in-situ detection via Ribbon NAPL Samplers (RNS). Ribbon NAPL samplers were deployed in boreholes HFM-1, HFM-2, and HFM-3 in February 1999 following the initial soil-gas surveys at each location. The Ribbon NAPL samplers were deployed and retrieved using FLUTe membrane based technology. After retrieval the membrane was visually inspected in the field for staining and field surveyed with a PID. After deployment the Ribbon NAPL sampler that was deployed at HFM-I showed no staining while those deployed at HFM2 and HFM-3 had various degrees of staining in the 15 to 25 foot interval. Although high soil-gas concentrations were observed at a depth of 60 feet at HFM-2, no staining was observed at this depth. The 
largest amount of staining was observed at HFM-3 at a depth of approximately 23 feet. The observed staining at this location and interval is presented in Figure 8. The staining presented in this figure is considered to be a result of contact with subsurface DNAPL that is present in distinct, thin layers and is controlled by small-scale heterogeneity. In addition to the visual staining caused by DNAPL, the interval between 5 and 20 feet of the Ribbon NAPL Sampler deployed at HFM-2 was observed to be moist. Although the Ribbon NAPL Sampler is constructed from hydrophobic materials, this moisture is believed to be associated with current discharges to the A-014 Outfall. The increased moisture in this area is considered to be associated with infiltration near the headwater of the outfall. This increase in soil moisture should have an effect on the resulting DNAPL distribution in the area. Upon completion boreholes HFM-1, HFM-2, and HFM-3 were abandoned using the Tremie Grouting Method per Chapter 9, Cone Penetrometer Tets, of Manual 3Q5 (WSRC, 1997).

Following the initial RNS deployments in February, additional soil-gas surveys were conducted in April 1999 to determine the possible extent of DNAPL in the shallow vadose zone near the headwaters. During this portion of the investigation the only locations having soil-gas survey results indicative of a nearby DNAPL were locations MVE-13 and MVE-17, these respectively correspond to the previous locations HFM-2 and HFM-3. In April 1999 the Ribbon NAPL Sampler was deployed in the borehole at MVE-17 which is within 12" of the previous HFM-3 investigation. Upon retrieval, staining was again observed in the 22 to 24 foot interval with very little staining observed in the 15 to 18 foot interval. The most extensive amount of staining was observed in the 11 to 12 foot interval where soil-gas samples could not be collected due to low permeability of the sediments.

In determining the presence or absence of DNAPL at a site, a weight of evidence approach is necessary. This is emphasized from the Ribbon NAPL Sampler results at locations HFM-3 and MVE-17. A graphical summary of these results is presented in Figure 9 and allows for a comparison of the depths where DNAPL was detected using the Ribbon NAPL Sampler at HFM-2, HFM-3, and at MVE-17. The difference in results between HFM-3 and MVE-17 reflect and emphasis the complexity of identifying and characterizing DNAPL in the subsurface. Results from HFM-3 indicate that DNAPL is present at depths of 14.5 feet, 16.5 - 17.5 feet, 19.5 feet, and $22.0-25.0$ feet. Subsequent characterization and deployment associated with MVE-17 further identified the interval between 10.5 and 12.5 feet as an interval that contains DNAPL. Based on soil gas concentrations collected in February of 1999 at HFM-2, DNAPL is also expected to be located at a depth of 60 feet below the ground surface. The Ribbon NAPL Sampler deployed at this location indicated DNAPL at shallow depths (10-25 feet) but not at 60 feet. These results illustrate the need for a variety of diverse and different tools in characterizing the presence and magnitude of DNAPL in the subsurface. 


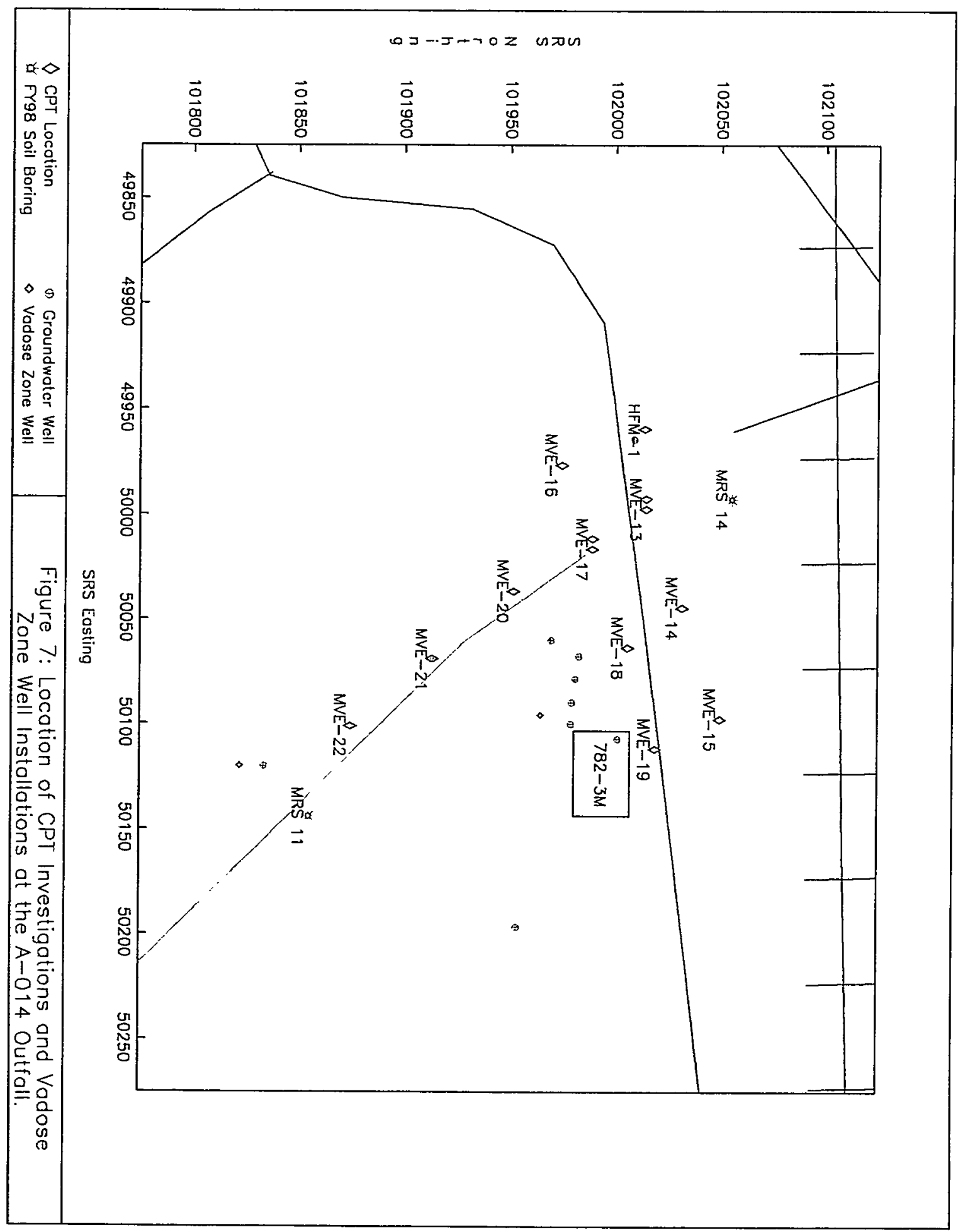

Figure 7: Location of CPT Investigations and Vadose Zone Well Installations at the A-014 Outfall. 
Table 2: Depth Discrete Soil Gas Concentrations Collected at HFM-1. (Samples collected and analyzed February 23, 1999)

\begin{tabular}{|c|c|c|c|c|c|c|c|c|c|}
\hline $\begin{array}{c}\text { Elevation } \\
\text { (depth) }\end{array}$ & $\begin{array}{c}\text { PCE } \\
\text { (ppmv) }\end{array}$ & $\begin{array}{c}\text { TCE } \\
\text { (ppmv) }\end{array}$ & $\begin{array}{c}\mathrm{CO}_{2} \\
\text { (ppmv) }\end{array}$ & $\mathrm{H}_{2} \mathrm{O}\left({ }^{\circ} \mathrm{C}\right)$ & $\begin{array}{c}\text { Elevation } \\
\text { (depth) }\end{array}$ & $\begin{array}{c}\text { PCE } \\
\text { (ppmv) }\end{array}$ & $\begin{array}{c}\text { TCE } \\
\text { (ppmv) }\end{array}$ & $\begin{array}{c}\mathrm{CO}_{2} \\
\text { (ppmv) }\end{array}$ & $\mathrm{H}_{2} \mathrm{O}\left({ }^{\circ} \mathrm{C}\right)$ \\
\hline$\left(15^{\prime}\right)$ & $\begin{array}{l}0.0 \\
0.1\end{array}$ & $\begin{array}{l}0.0 \\
0.0\end{array}$ & $\begin{array}{l}1,400 \\
1,460\end{array}$ & $\begin{array}{l}0.0 \\
0.0\end{array}$ & \multirow[t]{2}{*}{$\left(60^{\prime}\right)$} & $\begin{array}{l}56.9 \\
56.9\end{array}$ & $\begin{array}{l}0.0 \\
0.0\end{array}$ & $\begin{array}{l}4,120 \\
4,000\end{array}$ & $\begin{array}{l}8.3 \\
8.0\end{array}$ \\
\hline \multirow[t]{2}{*}{-15} & $\overline{0.0}$ & $\overline{0.0}$ & $\overline{1,430}$ & 0.0 & & 58.6 & 0.0 & 4,000 & 8.2 \\
\hline & 0.4 & 0.0 & 1,350 & 4.6 & \multirow[t]{2}{*}{-60} & $\overline{57.5}$ & $0 . \overline{0}$ & 4,040 & $\overline{8.2}$ \\
\hline$\left(20^{\prime}\right)$ & 0.1 & 0.0 & 1,350 & 4.8 & & 23.4 & 0.0 & 3,790 & 8.8 \\
\hline \multirow{2}{*}{-20} & 0.3 & 0.0 & 1,350 & 4.7 & \multirow[t]{2}{*}{$\left(65^{\prime}\right)$} & 14.1 & 0.0 & 3,470 & 8.9 \\
\hline & 0.5 & 0.0 & 1,410 & 2.7 & & 10.8 & 0.0 & 3,260 & 8.9 \\
\hline$\left(25^{\prime}\right)$ & 0.6 & 0.0 & 1,330 & 2.9 & -65 & $\overline{\overline{16.1}}$ & $\overline{0.0}$ & 3,507 & $\overline{8.9}$ \\
\hline \multirow[t]{2}{*}{-25} & 0.5 & 0.0 & 1,370 & $\overline{2.8}$ & \multirow[b]{2}{*}{$\left(70^{\prime}\right)$} & 7.5 & 0.0 & 3,590 & 7.4 \\
\hline & 0.4 & 0.0 & 1,770 & 6.2 & & 6.3 & 0.0 & 3,360 & 7.8 \\
\hline$\left(30^{\prime}\right)$ & 0.7 & 0.0 & 1,770 & 6.3 & -70 & 6.9 & 0.0 & $\overline{3,475}$ & $\overline{7.6}$ \\
\hline \multirow[t]{2}{*}{-30} & 0.6 & 0.0 & 1,770 & 6.2 & \multirow[b]{2}{*}{$\left(75^{\prime}\right)$} & 4.9 & 0.0 & 8,360 & 13.7 \\
\hline & 0.2 & 0.0 & 1,160 & 5.4 & & 4.1 & 0.0 & 8,610 & 15.0 \\
\hline$\left(35^{\prime}\right)$ & 0.2 & 0.0 & 1,000 & 5.6 & -75 & $\overline{4.5}$ & 0.0 & 8,485 & $\overline{14.4}$ \\
\hline \multirow[t]{2}{*}{-35} & 0.2 & 0.0 & 1,080 & $\overline{5.5}$ & \multirow[b]{2}{*}{$\left(80^{\prime}\right)$} & 3.3 & 0.0 & 9,980 & 19.5 \\
\hline & 0.2 & 0.0 & 2,690 & 6.8 & & 2.8 & 0.0 & 9,810 & 22.1 \\
\hline$\left(40^{\prime}\right)$ & 0.1 & 0.0 & 2,680 & 6.7 & -80 & 3.0 & 0.0 & 9,895 & 20.8 \\
\hline \multirow[t]{2}{*}{-40} & 0.2 & 0.0 & 2,685 & 6.7 & $\left(85^{\prime}\right)$ & \multicolumn{3}{|c|}{ (Vacuum to High) } & \\
\hline & 0.2 & 0.0 & 3,410 & 6.5 & \multirow[t]{2}{*}{-85} & \multicolumn{3}{|c|}{ (Vacuum to High) } & \\
\hline$\left(45^{\prime}\right)$ & 0.3 & 0.0 & 3,240 & 6.7 & & 17.3 & 0.0 & 7,160 & 25.3 \\
\hline \multirow[t]{2}{*}{-45} & 0.2 & 0.0 & 3,325 & 6.6 & $\left(95^{\prime}\right)$ & 17.4 & 0.0 & 7,130 & 19.6 \\
\hline & 0.3 & 0.0 & 3,160 & 7.5 & \multirow[t]{2}{*}{-95} & 77.4 & 0.0 & 7,745 & 22.5 \\
\hline$\left(50^{\prime}\right)$ & 0.3 & 0.0 & 3,110 & 7.3 & & 4.8 & 0.0 & 8,820 & 75.6 \\
\hline \multirow[t]{2}{*}{-50} & 0.3 & 0.0 & 3,135 & 7.4 & $\left(100^{\prime}\right)$ & 4.2 & 0.0 & 7,570 & 15.7 \\
\hline & 18.3 & 0.9 & 3,510 & 8.7 & -700 & 4.5 & 0.0 & 8,795 & 15.7 \\
\hline$\left(55^{\prime}\right)$ & 38.3 & 1.0 & 3,260 & 8.1 & $\left(105^{\prime}\right)$ & (Va & usm to His & & \\
\hline & 47.8 & 1.1 & 3,210 & 8.2 & -105 & (Vac & um to $\mathrm{Hi}$ & & \\
\hline & 52.6 & 1.1 & 3,130 & 8.2 & $\left(110^{\prime}\right)$ & $(\mathrm{Va}$ & Ium to Hic & & \\
\hline-55 & 39.3 & 1.0 & 3,278 & 8.3 & -110 & (Vac & Ium to $\mathrm{Hi}$ & & \\
\hline
\end{tabular}


Table 3: Depth Discrete Soil Gas Concentrations Collected at HFM-2. (Samples collected and analyzed February 23, 1999)

\begin{tabular}{|c|c|c|c|c|}
\hline $\begin{array}{c}\text { Elevation } \\
\text { (depth) }\end{array}$ & $\begin{array}{c}\text { PCE } \\
\text { (ppmv) }\end{array}$ & $\begin{array}{c}\text { TCE } \\
\text { (ppmv) }\end{array}$ & $\begin{array}{c}\mathrm{CO}_{2} \\
\text { (ppmv) }\end{array}$ & $\mathrm{H}_{2} \mathrm{O}\left({ }^{\circ} \mathrm{C}\right)$ \\
\hline$\left(15^{1}\right)$ & \multicolumn{3}{|c|}{ (Vacuum to High) } & \\
\hline \multirow[t]{2}{*}{-15} & \multicolumn{3}{|c|}{ (Vacuum to High) } & \\
\hline & 30.0 & 25.0 & 1,540 & 23.2 \\
\hline \multirow[t]{3}{*}{$\left(20^{\prime}\right)$} & $3,340.0$ & 47.9 & 1,510 & 25.2 \\
\hline & $1,230.0$ & 1.5 & 1,170 & 23.5 \\
\hline & $1,010.0$ & 0.3 & 1,130 & 23.3 \\
\hline \multirow[t]{2}{*}{-20} & $1,402.5$ & 18.7 & 1,338 & 23.8 \\
\hline & $2,040.0$ & 766.0 & 8,070 & 18.8 \\
\hline \multirow[t]{2}{*}{$\left(25^{\prime}\right)$} & $4,260.0$ & $1,140.0$ & 9,550 & 19.4 \\
\hline & $5,250.0$ & $1,210.0$ & 9,260 & 19.3 \\
\hline \multirow[t]{2}{*}{-25} & $3,850.0$ & $1,038.7$ & 8,960 & 19.2 \\
\hline & $3,300.0$ & 783.0 & 9,200 & 17.5 \\
\hline \multirow[t]{2}{*}{$\left(30^{\prime}\right)$} & $3,840.0$ & 857.0 & 9,140 & 20.2 \\
\hline & $3,950.0$ & 865.0 & 9,010 & 18.5 \\
\hline \multirow[t]{2}{*}{30} & $3,696.7$ & 835.0 & 9,117 & $\overline{18.7}$ \\
\hline & $2,360.0$ & 215.0 & 7,580 & 20.2 \\
\hline \multirow[t]{2}{*}{$\left(35^{\prime}\right)$} & $2,600.0$ & 216.0 & 7,590 & 20.3 \\
\hline & $2,610.0$ & 208.0 & 7,530 & 20.5 \\
\hline \multirow[t]{2}{*}{-35} & $2,523.3$ & 213.0 & $\overline{7,567}$ & 20.3 \\
\hline & $2,240.0$ & 96.5 & 7,540 & 20.8 \\
\hline \multirow[t]{2}{*}{$\left(40^{\prime}\right)$} & $2,270.0$ & 93.7 & 7,470 & 21.6 \\
\hline & $2,280.0$ & 91.1 & 7,370 & 21.1 \\
\hline \multirow[t]{2}{*}{-40} & $2,263.3$ & 93.8 & 7,460 & 21.2 \\
\hline & $2,090.0$ & 46.6 & 8,710 & 20.0 \\
\hline \multirow[t]{2}{*}{$\left(45^{\prime}\right)$} & $2,150.0$ & 44.7 & 8,590 & 20.3 \\
\hline & $2,160.0$ & 43.4 & 8,490 & 20.0 \\
\hline \multirow[t]{2}{*}{-45} & $2,133.3$ & 44.9 & 8,597 & 20.1 \\
\hline & $1,460.0$ & 15.0 & 9,150 & 21.3 \\
\hline \multirow[t]{2}{*}{$\left(50^{\prime}\right)$} & $1,570.0$ & 14.2 & 9,040 & 22.9 \\
\hline & $1,580.0$ & 13.5 & 8,880 & 23.1 \\
\hline-50 & $1,536.7$ & 14.2 & 9,023 & 22.4 \\
\hline$\left(55^{\prime}\right)$ & \multicolumn{3}{|c|}{ (Vacuum to High) } & \\
\hline \multicolumn{4}{|c|}{$-55 \quad$ (Vacuum to High) } & \\
\hline
\end{tabular}

\begin{tabular}{|c|c|c|c|c|}
\hline $\begin{array}{c}\text { Elevation } \\
\text { (depth) }\end{array}$ & $\begin{array}{c}\mathrm{PCE} \\
\text { (ppmv) }\end{array}$ & $\begin{array}{c}\text { TCE } \\
(\mathrm{ppmv})\end{array}$ & $\begin{array}{c}\mathrm{CO}_{2} \\
\text { (ppmv) }\end{array}$ & $\mathrm{H}_{2} \mathrm{O}\left({ }^{\circ} \mathrm{C}\right)$ \\
\hline \multirow{4}{*}{$(-60)$} & $2,990.0$ & 676.0 & 8,860 & 22.4 \\
\hline & $4,130.0$ & 790.0 & 8,920 & 22.7 \\
\hline & $4,610.0$ & 844.0 & 8,830 & 22.8 \\
\hline & $\begin{array}{l}4,840.0 \\
5,260.0\end{array}$ & $\begin{array}{l}869.0 \\
9100\end{array}$ & $\begin{array}{l}8,810 \\
8670\end{array}$ & 23.0 \\
\hline \multirow[t]{2}{*}{-60} & $4,366.0$ & 817.8 & 8,818 & 22.8 \\
\hline & $2,020.0$ & 119.0 & 6,390 & 21. \\
\hline$\left(65^{\prime}\right)$ & $\begin{array}{l}1,670.0 \\
1,450.0\end{array}$ & $\begin{array}{l}98.9 \\
87.0\end{array}$ & $\begin{array}{l}5,910 \\
5,540\end{array}$ & $\begin{array}{l}21.8 \\
21.4\end{array}$ \\
\hline \multirow[t]{2}{*}{-65} & $1,713.3$ & $\overline{101.6}$ & 5,947 & 21.6 \\
\hline & 648.0 & 19.4 & 8,010 & 20.4 \\
\hline$\frac{\left(70^{\prime}\right)}{70}$ & 590.0 & 17.9 & 7,860 & 20.3 \\
\hline \multirow[t]{2}{*}{-70} & 619.0 & 18.7 & 7,935 & 20.4 \\
\hline & 416.0 & 8.3 & 9,040 & $\overline{19.2}$ \\
\hline \multirow[t]{2}{*}{$\left(75^{\prime}\right)$} & 355.0 & 6.9 & 8,700 & 19.3 \\
\hline & 385.5 & $\overline{7.6}$ & 8,870 & 19.3 \\
\hline \multirow{2}{*}{$\left(80^{\prime}\right)$} & 786.0 & 19.1 & 8,020 & 19.5 \\
\hline & 758.0 & 18.2 & 8,060 & 19.3 \\
\hline \multirow[t]{2}{*}{-80} & 772.0 & 18.7 & 8,040 & 19.4 \\
\hline & 347.0 & 5.7 & 8,050 & $\overline{19.9}$ \\
\hline$\left(85^{\prime}\right)$ & 308.0 & 5.2 & 7,830 & 20.3 \\
\hline \multirow[t]{2}{*}{-85} & 327.5 & $\overline{5.5}$ & 7,940 & 20.1 \\
\hline & 281.0 & $\overline{6.4}$ & 5,110 & 20.6 \\
\hline \multirow[t]{2}{*}{$\left(90^{\prime}\right)$} & 403.0 & 8.4 & 6,320 & 19.5 \\
\hline & 385.0 & 8.0 & 6,370 & 20.3 \\
\hline-90 & 356.3 & 7.6 & 5,933 & 20.1 \\
\hline \multirow[b]{2}{*}{$\left(95^{\prime}\right)$} & 211.0 & 1.7 & 14,000 & 21.3 \\
\hline & 188.0 & 1.2 & 14,300 & 21.2 \\
\hline \multirow[t]{2}{*}{-95} & $19 \overline{199.5}$ & $\overline{1.4}$ & 14,150 & $\overline{21.3}$ \\
\hline & 213.0 & 2.7 & 16,700 & 21.6 \\
\hline \multirow{2}{*}{$\frac{\left(100^{\prime}\right)}{-100}$} & 194.0 & 1.8 & 17,200 & 21.6 \\
\hline & 203.5 & 2.3 & 16,950 & 21.6 \\
\hline$\left(105^{\prime}\right)$ & \multicolumn{3}{|c|}{ (Vacuum to High) } & \\
\hline \multirow{2}{*}{$\frac{-105}{\left(110^{\prime}\right)}$} & \multicolumn{3}{|c|}{ (Vacuum to High) } & \\
\hline & \multicolumn{3}{|c|}{ (Vacuum to High) } & \\
\hline-1 & $\overline{\mathrm{Va}}$ & $\mathrm{Jm}$ to $\mathrm{Hi}$ & & \\
\hline
\end{tabular}


Table 4: Depth Discrete Soil Gas Concentrations Collected at HFM-3. (Samples collected and analyzed February 24, 1999)

\begin{tabular}{|c|c|c|c|c|}
\hline $\begin{array}{l}\text { Elevation } \\
\text { (depth) }\end{array}$ & $\begin{array}{c}\text { PCE } \\
(\mathrm{ppmv})\end{array}$ & $\begin{array}{c}\text { TCE } \\
\text { (ppmv) }\end{array}$ & $\begin{array}{c}\mathrm{CO}_{2} \\
\text { (ppmv) }\end{array}$ & $\mathrm{H}_{2} \mathrm{O}\left({ }^{\circ} \mathrm{C}\right)$ \\
\hline$\left(15^{\prime}\right)$ & \multicolumn{3}{|c|}{ (Vacuum to High) } & \\
\hline-15 & \multicolumn{3}{|c|}{ (Vacuum to High) } & \\
\hline \multirow{5}{*}{$\left(20^{\prime}\right)$} & $3,900.0$ & 56.5 & 1,060 & 26.2 \\
\hline & $4,800.0$ & 77.9 & 1,110 & 26.5 \\
\hline & $5,240.0$ & 88.5 & 1,170 & 26.0 \\
\hline & $5,520.0$ & 96.4 & 1,150 & 25.6 \\
\hline & $6,680.0$ & 133.0 & 1,010 & 24.1 \\
\hline \multirow[t]{2}{*}{-20} & $\overline{5,228.0}$ & $\overline{90.5}$ & 1,100 & 25.7 \\
\hline & $5,250.0$ & 130.0 & 3,100 & 24.3 \\
\hline \multirow[t]{2}{*}{ (25') } & $5,350.0$ & 138.0 & 3,120 & 25.1 \\
\hline & $5,470.0$ & 144.0 & 3,150 & 25.2 \\
\hline \multirow[t]{2}{*}{-25} & $\overline{5,356.7}$ & $\overline{137.3}$ & $\overline{3,123}$ & $\overline{24.9}$ \\
\hline & $3,600.0$ & 25.7 & 2,500 & 15.4 \\
\hline \multirow[t]{2}{*}{$\left(30^{\prime}\right)$} & $3,550.0$ & 22.8 & 2,500 & 18.3 \\
\hline & $3,480.0$ & 21.2 & 2,480 & 23.8 \\
\hline \multirow[t]{2}{*}{-30} & $\overline{3,543.3}$ & $\overline{23.2}$ & 2,493 & $\overline{19.2}$ \\
\hline & $2,550.0$ & 6.8 & 1,500 & 23.0 \\
\hline \multirow[t]{2}{*}{ (35') } & $3,040.0$ & 9.9 & 1,810 & 18.4 \\
\hline & $3,120.0$ & 9.8 & 1,940 & 16.2 \\
\hline \multirow[t]{2}{*}{-35} & $2,903.3$ & 8.8 & 1,750 & $\overline{19.2}$ \\
\hline & $2,280.0$ & 2.6 & 1,480 & 15.4 \\
\hline \multirow{2}{*}{$\frac{\left(40^{\prime}\right)}{-40}$} & $2,130.0$ & 1.8 & 1,450 & 16.5 \\
\hline & $2,205.0$ & $\overline{2.2}$ & $\overline{1,465}$ & $\overline{16.0}$ \\
\hline \multirow{3}{*}{$\left(50^{\prime}\right)$} & $2,720.0$ & 7.3 & 1,520 & 19.9 \\
\hline & $2,390.0$ & 3.8 & 1,540 & 18.4 \\
\hline & $2,210.0$ & 2.5 & 1,520 & 16.1 \\
\hline-50 & $2,440.0$ & 4.5 & 1,527 & $\overline{18.1}$ \\
\hline
\end{tabular}

\begin{tabular}{|c|rrrr|}
\hline $\begin{array}{c}\text { Elevation } \\
\text { (depth) }\end{array}$ & $\begin{array}{c}\text { PCE } \\
\text { (ppmv) }\end{array}$ & \multicolumn{1}{c}{$\begin{array}{c}\mathrm{TCE} \\
\text { (ppmv) }\end{array}$} & \multicolumn{1}{c|}{$\begin{array}{c}\mathrm{CO}_{2} \\
\text { (ppmv) }\end{array}$} & $\mathrm{H}_{2} \mathrm{O}\left({ }^{\circ} \mathrm{C}\right)$ \\
\hline & $2,430.0$ & 7.6 & 1,650 & 23.8 \\
$(-60)$ & $2,420.0$ & 4.8 & 948 & 23.9 \\
\hline \hline-60 & $2,425.0$ & 6.2 & 1,299 & 23.9 \\
\hline & 939.0 & 0.0 & 6,490 & 16.0 \\
$\left(70^{\prime}\right)$ & 929.0 & 0.0 & 9,270 & 15.9 \\
\hline \hline-70 & 934.0 & 0.0 & 7,880 & 16.0 \\
\hline & 885.0 & 0.0 & 8,050 & 23.5 \\
$\left(80^{\prime}\right)$ & 994.0 & 0.0 & 10,400 & 15.8 \\
& 943.0 & 0.0 & 10,700 & 16.0 \\
\hline \hline-80 & 940.7 & 0.0 & 9,717 & 18.4 \\
\hline & 897.0 & 0.0 & 15,000 & 23.4 \\
$\left(90^{\prime}\right)$ & $1,050.0$ & 0.0 & 14,900 & 23.7 \\
& $1,010.0$ & 0.0 & 14,800 & 23.9 \\
& 995.0 & 0.0 & 14,700 & 23.5 \\
\hline \hline-90 & 988.0 & 0.0 & 14,850 & 23.6 \\
\hline & 748.0 & 0.0 & 14,600 & 22.0 \\
$\left(100^{\prime}\right)$ & 865.0 & 0.0 & 14,800 & 22.1 \\
& 880.0 & 0.0 & 14,700 & 21.6 \\
\hline \hline-100 & 831.0 & 0.0 & 14,700 & 21.9 \\
\hline & $1,390.0$ & 1.6 & 6,430 & 24.3 \\
\hline$\left(110^{\prime}\right)$ & $1,460.0$ & 1.4 & 4,110 & 24.4 \\
& $1,470.0$ & 1.4 & 3,290 & 24.2 \\
\hline-110 & $1,440.0$ & 1.5 & 4,610 & 24.3 \\
\hline
\end{tabular}


Table 5: Soil Gas Concentrations from Vadose Monitoring Probes MVC-2 and MVC-3 located at the A-014 Outfall (Samples Collected and Analyzed April 22, 1999).

\begin{tabular}{|c|c|c|c|c|c|}
\hline $\begin{array}{l}\text { Identification } \\
\text { (depth) }\end{array}$ & PCE (ppmv) & TCE (ppmv) & $\mathrm{CCl}_{4}(\mathrm{ppmv})$ & $\mathrm{CO}_{2}$ (ppmv) & $\mathrm{H}_{2} \mathrm{O}\left({ }^{\circ} \mathrm{C}\right)$ \\
\hline \multirow{4}{*}{$\left(44.5-49.5^{\prime}\right)$} & $1,620.0$ & 93.20 & 0.00 & $n / a$ & $n / a$ \\
\hline & $1,310.0$ & 86.10 & 0.00 & 20,500 & 27.7 \\
\hline & $1,170.0$ & 78.60 & 0.00 & 21,500 & 27.6 \\
\hline & $1,090.0$ & 72.50 & 0.00 & 22,200 & 27.6 \\
\hline \multirow[t]{2}{*}{ MVC-2-B1 } & $1,297.5$ & 82.60 & 0.00 & 21,400 & $\overline{27.6}$ \\
\hline & $n / a$ & $n / a$ & $n / a$ & $n / a$ & $n / a$ \\
\hline \multirow{2}{*}{$\left(67.8-72.8^{\prime}\right)$} & $n / a$ & $n / a$ & $n / a$ & $n / a$ & $n / a$ \\
\hline & $n / a$ & $n / a$ & $n / a$ & $n / a$ & $n / a$ \\
\hline MVC-2-B2 & $\mathbf{n} \mathbf{a}$ & $n / a$ & $n / a$ & $n / a$ & $n / a$ \\
\hline \multirow{3}{*}{$\left(102.0-107.0^{\prime}\right)$} & $1,990.0$ & 90.40 & 3.10 & 3,310 & 26.8 \\
\hline & $2,300.0$ & 123.00 & 3.10 & 3,310 & 26.8 \\
\hline & $2,290.0$ & 124.00 & 5.80 & 3,270 & 26.8 \\
\hline MVC-2-B3 & $2,193.3$ & 112.47 & 4.00 & 3,297 & 26.8 \\
\hline \multirow{4}{*}{$\left(48.0-53.0^{\prime}\right)$} & 39.5 & 10.00 & 0.00 & 1,120 & 26.4 \\
\hline & 188.0 & 53.00 & 0.00 & 21,700 & 25.7 \\
\hline & 401.0 & 114.00 & 0.00 & 38,800 & 26.4 \\
\hline & 202.0 & 54.90 & 0.00 & 48,000 & 25.8 \\
\hline \multirow{2}{*}{ MVC-3-B1 } & 263.7 & 73.97 & 0.00 & 36,167 & 26.1 \\
\hline & 110.0 & 43.10 & 0.00 & 13,500 & 27.6 \\
\hline \multirow{2}{*}{$\left(65.0-70.0^{\prime}\right)$} & 69.1 & 25.10 & 0.00 & 14,000 & 26.0 \\
\hline & 18.2 & 6.21 & 0.00 & 15,300 & 26.1 \\
\hline \multirow[t]{2}{*}{ MVC-3-B2 } & 65.8 & 24.80 & 0.00 & 14,267 & $\overline{26.6}$ \\
\hline & 132.0 & 21.50 & 0.00 & 8,820 & 26.4 \\
\hline \multirow{2}{*}{$\left(102.0-107.0^{\prime}\right)$} & 24.7 & 7.57 & 0.00 & 8,510 & 26.1 \\
\hline & 18.2 & 7.31 & 0.00 & 8,530 & 25.9 \\
\hline MVC-3-B3 & 58.3 & 12.13 & 0.00 & 8,620 & 26.1 \\
\hline
\end{tabular}


Table 6: Depth Discrete Soil Gas Concentrations Collected Prior to the Installation of MVE-13. (Samples collected and analyzed April 20, 1999)

\begin{tabular}{|c|rrrrr|}
\hline $\begin{array}{c}\text { Elevation } \\
\text { (depth) }\end{array}$ & $\begin{array}{c}\text { PCE } \\
\text { (ppmv) }\end{array}$ & \multicolumn{1}{c}{$\begin{array}{c}\mathrm{TCE} \\
\text { (ppmv) }\end{array}$} & \multicolumn{1}{c}{$\begin{array}{c}\mathrm{CCl}_{4} \\
\text { (ppmv) }\end{array}$} & $\begin{array}{c}\mathrm{CO}_{2} \\
\text { (ppmv) }\end{array}$ & $\mathrm{H}_{2} \mathrm{O}\left({ }^{\circ} \mathrm{C}\right)$ \\
\hline & $1,500.0$ & 54.3 & 0.00 & 2,380 & 16.5 \\
$\left(20^{\prime}\right)$ & $1,350.0$ & 42.3 & 0.00 & 1,640 & 16.4 \\
& $1,840.0$ & 41.7 & 0.00 & 1,690 & 16.5 \\
\hline-20 & $1,563.3$ & 46.1 & 0.00 & 1,903 & 16.5 \\
\hline & $4,040.0$ & $1,680.0$ & 46.40 & 7,510 & 17.0 \\
$\left(25^{\prime}\right)$ & $4,860.0$ & $1,860.0$ & 92.60 & 7,660 & 19.9 \\
& $5,140.0$ & $1,910.0$ & 114.00 & 7,630 & 20.8 \\
\hline \hline-25 & $4,680.0$ & $1,816.7$ & 84.33 & 7,600 & 19.2 \\
\hline & $3,270.0$ & 970.0 & 18.00 & 6,360 & 21.6 \\
$\left(30^{\prime}\right)$ & $4,280.0$ & $1,140.0$ & 55.00 & 6,610 & 22.5 \\
& $4,530.0$ & $1,150.0$ & 71.20 & 6,570 & 23.2 \\
\hline-30 & $4,026.7$ & $1,086.7$ & 48.07 & 6,513 & 22.4 \\
\hline & $1,960.0$ & 167.0 & 0.00 & 4,190 & 23.7 \\
$\left(35^{\prime}\right)$ & $2,900.0$ & 257.0 & 3.28 & 5,710 & 23.8 \\
& $3,410.0$ & 303.0 & 20.90 & 6,260 & 24.1 \\
\hline \hline-35 & $2,756.7$ & 242.3 & 8.06 & 5,387 & 23.9 \\
\hline & $2,650.0$ & 120.0 & 0.00 & 6,300 & 24.3 \\
$\left(40^{\prime}\right)$ & $3,090.0$ & 130.0 & 8.29 & 6,590 & 24.5 \\
& $3,240.0$ & 133.0 & 12.20 & 6,690 & 24.5 \\
\hline-40 & $2,993.3$ & 127.7 & 6.83 & 6,527 & 24.4 \\
\hline \hline
\end{tabular}


Table 7: Depth Discrete Soil Gas Concentrations Collected Prior to the Installation of MVE-14. (Samples collected and analyzed April 19, 1999)

\begin{tabular}{|c|c|c|c|c|c|}
\hline $\begin{array}{c}\text { Elevation } \\
\text { (depth) }\end{array}$ & $\begin{array}{c}\text { PCE } \\
(\mathrm{ppmv})\end{array}$ & $\begin{array}{c}\text { TCE } \\
\text { (ppmv) }\end{array}$ & $\begin{array}{c}\mathrm{CCl}_{4} \\
\text { (ppmv) }\end{array}$ & $\begin{array}{c}\mathrm{CO}_{2} \\
\text { (ppmv) }\end{array}$ & $\mathrm{H}_{2} \mathrm{O}\left({ }^{\circ} \mathrm{C}\right)$ \\
\hline$\left(15^{\prime}\right)$ & $\begin{array}{l}1.51 \\
2.50 \\
1.88 \\
\end{array}$ & $\begin{array}{l}0.23 \\
0.11 \\
0.06 \\
\end{array}$ & $\begin{array}{l}0.00 \\
0.00 \\
0.00 \\
\end{array}$ & $\begin{array}{r}718 \\
943 \\
1,430 \\
\end{array}$ & $\begin{array}{l}14.8 \\
20.0 \\
19.9 \\
\end{array}$ \\
\hline-15 & 1.96 & 0.13 & 0.00 & 1,030 & 18.2 \\
\hline$\left(20^{\prime}\right)$ & $\begin{array}{l}2.05 \\
1.89 \\
1.78 \\
\end{array}$ & $\begin{array}{l}0.18 \\
0.26 \\
0.00 \\
\end{array}$ & $\begin{array}{l}0.07 \\
0.04 \\
0.09 \\
\end{array}$ & $\begin{array}{r}908 \\
982 \\
1,320 \\
\end{array}$ & $\begin{array}{l}18.9 \\
19.6 \\
19.3 \\
\end{array}$ \\
\hline-20 & 1.91 & 0.15 & 0.07 & 1,070 & 19.3 \\
\hline (25') & $\begin{array}{l}1.84 \\
1.87 \\
1.91 \\
\end{array}$ & $\begin{array}{l}0.00 \\
0.03 \\
0.00 \\
\end{array}$ & $\begin{array}{l}0.00 \\
0.02 \\
0.05 \\
\end{array}$ & $\begin{array}{l}766 \\
819 \\
798 \\
\end{array}$ & $\begin{array}{l}16.7 \\
17.8 \\
18.2 \\
\end{array}$ \\
\hline-25 & 1.87 & 0.01 & 0.02 & 794 & 17.6 \\
\hline$\left(30^{\prime}\right)$ & $\begin{array}{l}1.34 \\
1.37 \\
1.11 \\
\end{array}$ & $\begin{array}{l}0.00 \\
0.00 \\
0.00 \\
\end{array}$ & $\begin{array}{l}0.00 \\
0.00 \\
0.00 \\
\end{array}$ & $\begin{array}{l}3,540 \\
4,110 \\
4,180 \\
\end{array}$ & \begin{tabular}{|l|}
17.9 \\
18.3 \\
18.3 \\
\end{tabular} \\
\hline-30 & 1.27 & 0.00 & 0.00 & 3,943 & 18.2 \\
\hline$\left(35^{\prime}\right)$ & $\begin{array}{l}1.15 \\
1.15 \\
1.03 \\
\end{array}$ & $\begin{array}{l}0.00 \\
0.00 \\
0.00 \\
\end{array}$ & $\begin{array}{l}0.00 \\
0.00 \\
0.00 \\
\end{array}$ & $\begin{array}{r}495 \\
5,020 \\
5,040 \\
\end{array}$ & $\begin{array}{r}0.8 \\
18.0 \\
18.3 \\
\end{array}$ \\
\hline-35 & 1.11 & 0.00 & 0.00 & 3.518 & 12.4 \\
\hline$\left(40^{\prime}\right)$ & $\begin{array}{l}1.20 \\
1.10 \\
1.10 \\
\end{array}$ & $\begin{array}{l}0.00 \\
0.00 \\
0.00 \\
\end{array}$ & $\begin{array}{l}0.00 \\
0.00 \\
0.00 \\
\end{array}$ & $\begin{array}{l}3,790 \\
4,040 \\
3,930 \\
\end{array}$ & $\begin{array}{l}18.0 \\
18.5 \\
18.5 \\
\end{array}$ \\
\hline-40 & 1.13 & 0.00 & 0.00 & 3,920 & 18.3 \\
\hline$\left(45^{\prime}\right)$ & $\begin{array}{l}1.17 \\
0.93 \\
0.95 \\
\end{array}$ & $\begin{array}{l}0.00 \\
0.00 \\
0.00 \\
\end{array}$ & $\begin{array}{l}0.00 \\
0.00 \\
0.00 \\
\end{array}$ & $\begin{array}{r}4,180 \\
4,280 \\
4,180 \\
\end{array}$ & $\begin{array}{l}18.0 \\
18.4 \\
18.4 \\
\end{array}$ \\
\hline-45 & 1.01 & 0.00 & 0.00 & 4,213 & 18.3 \\
\hline$\left(50^{\prime}\right)$ & $\begin{array}{l}1.00 \\
1.05 \\
0.89 \\
\end{array}$ & $\begin{array}{l}0.00 \\
0.00 \\
0.00 \\
\end{array}$ & $\begin{array}{l}0.00 \\
0.00 \\
0.00 \\
\end{array}$ & $\begin{array}{l}1,630 \\
3,160 \\
3,250 \\
\end{array}$ & $\begin{array}{l}16.6 \\
17.6 \\
17.9 \\
\end{array}$ \\
\hline-50 & 0.98 & 0.00 & 0.00 & 2,680 & 17.4 \\
\hline$\left(55^{\prime}\right)$ & $\begin{array}{l}1.46 \\
1.11 \\
1.16 \\
\end{array}$ & $\begin{array}{l}0.00 \\
0.00 \\
0.00 \\
\end{array}$ & $\begin{array}{l}0.00 \\
0.00 \\
0.00 \\
\end{array}$ & $\begin{array}{l}4,010 \\
3,860 \\
3,830 \\
\end{array}$ & $\begin{array}{l}17.4 \\
17.8 \\
18.0 \\
\end{array}$ \\
\hline-55 & 1.24 & 0.00 & 0.00 & 3,900 & 17.7 \\
\hline$\left(60^{\prime}\right)$ & $\begin{array}{l}0.94 \\
1.06 \\
1.03 \\
\end{array}$ & $\begin{array}{l}0.00 \\
0.00 \\
0.00 \\
\end{array}$ & $\begin{array}{l}0.00 \\
0.00 \\
0.00 \\
\end{array}$ & $\begin{array}{l}5,210 \\
5,610 \\
5,660 \\
\end{array}$ & $\begin{array}{l}16.4 \\
16.9 \\
17.0 \\
\end{array}$ \\
\hline-60 & 1.01 & 0.00 & 0.00 & 5,493 & 16.8 \\
\hline
\end{tabular}


Table 8: Depth Discrete Soil Gas Concentrations Collected Prior to the Installation of MVE-15. (Samples collected and analyzed April 19, 1999)

\begin{tabular}{|c|c|c|c|c|c|}
\hline $\begin{array}{c}\text { Elevation } \\
\text { (depth) }\end{array}$ & $\begin{array}{c}\mathrm{PCE} \\
\text { (ppmv) }\end{array}$ & $\begin{array}{c}\text { TCE } \\
\text { (ppmv) }\end{array}$ & $\begin{array}{c}\mathrm{CCl}_{4} \\
\text { (ppmv) }\end{array}$ & $\begin{array}{c}\mathrm{CO}_{2} \\
\text { (ppmv) }\end{array}$ & $\mathrm{H}_{2} \mathrm{O}\left({ }^{\circ} \mathrm{C}\right)$ \\
\hline \multirow{4}{*}{ (15') } & 2.27 & 0.10 & 0.00 & 1,150 & 20.2 \\
\hline & 2.10 & 0.12 & 0.02 & 1,530 & 20.8 \\
\hline & 2.01 & 0.17 & 0.01 & 1,990 & 20.9 \\
\hline & 1.96 & 0.03 & 0.05 & 2,000 & 21.0 \\
\hline-15 & 2.09 & 0.11 & 0.02 & 1,668 & 20.7 \\
\hline \multirow{3}{*}{$\left(20^{\prime}\right)$} & 2.63 & 0.95 & 0.28 & 1,340 & 21.2 \\
\hline & 2.19 & 0.70 & 0.30 & 1,380 & 21.4 \\
\hline & 2.31 & 0.72 & 0.15 & 1,310 & 21.5 \\
\hline \multirow[t]{2}{*}{-20} & 2.38 & 0.79 & 0.24 & 1,343 & 21.4 \\
\hline & 2.53 & 0.13 & 0.00 & 1,050 & 22.0 \\
\hline \multirow[t]{2}{*}{$\left(25^{\prime}\right)$} & 1.85 & 0.00 & 0.00 & 852 & 22.0 \\
\hline & 1.65 & 0.00 & 0.00 & 747 & 21.8 \\
\hline-25 & 2.01 & 0.04 & 0.00 & 883 & 21.9 \\
\hline \multirow{3}{*}{$\left(30^{\prime}\right)$} & 1.31 & 0.00 & 0.00 & 2,050 & 22.1 \\
\hline & 1.95 & 0.00 & 0.00 & 2,570 & 22.4 \\
\hline & 1.03 & 0.00 & 0.00 & 2.640 & 22.4 \\
\hline-30 & 1.43 & 0.00 & 0.00 & 2,420 & 22.3 \\
\hline \multirow{3}{*}{ (35') } & 1.38 & 0.00 & 0.00 & 3,330 & 22.3 \\
\hline & 1.31 & 0.00 & 0.00 & 3,820 & 22.3 \\
\hline & 1.26 & 0.00 & 0.00 & 3,860 & 22.2 \\
\hline-35 & 1.32 & 0.00 & 0.00 & 3,670 & 22.3 \\
\hline \multirow{3}{*}{$\left(40^{\prime}\right)$} & 1.27 & 0.00 & 0.00 & 6,950 & 19.8 \\
\hline & 1.19 & 0.00 & 0.00 & 6,930 & 19.8 \\
\hline & 1.20 & 0.00 & 0.00 & 8,940 & 19.8 \\
\hline-40 & 1.22 & 0.00 & 0.00 & 7,607 & 19.8 \\
\hline \multirow{3}{*}{$\left(45^{\prime}\right)$} & 1.02 & 0.00 & 0.00 & 16,800 & 19.2 \\
\hline & 1.13 & 0.00 & 0.00 & 15,600 & 19.6 \\
\hline & 1.03 & 0.00 & 0.00 & 14,500 & 19.8 \\
\hline-45 & 1.06 & 0.00 & 0.00 & 15,633 & 19.5 \\
\hline \multirow{3}{*}{ (52') } & 1.36 & 0.00 & 0.00 & 3,200 & 18.4 \\
\hline & 1.51 & 0.00 & 0.00 & 2,340 & 19.0 \\
\hline & 1.73 & 0.00 & 0.00 & 1,910 & 19.0 \\
\hline-52 & 1.53 & 0.00 & 0.00 & 2,483 & 18.8 \\
\hline \multirow{3}{*}{ (57') } & 1.66 & 0.00 & 0.00 & 1,070 & 17.6 \\
\hline & 1.53 & 0.00 & 0.00 & 877 & 18.9 \\
\hline & 2.01 & 0.00 & 0.00 & 835 & 18.8 \\
\hline-57 & 1.73 & 0.00 & 0.00 & 927 & 18.4 \\
\hline
\end{tabular}


Table 9: Depth Discrete Soil Gas Concentrations Collected Prior to the Installation of MVE-16. (Samples collected and analyzed April 21, 1999)

\begin{tabular}{|c|c|c|c|c|c|}
\hline $\begin{array}{c}\text { Elevation } \\
\text { (depth) }\end{array}$ & $\begin{array}{c}\text { PCE } \\
(\mathrm{ppmv})\end{array}$ & $\begin{array}{c}\mathrm{TCE} \\
(\mathrm{ppmv})\end{array}$ & $\begin{array}{c}\mathrm{CCl}_{4} \\
(\mathrm{ppmv})\end{array}$ & $\begin{array}{c}\mathrm{CO}_{2} \\
\text { (ppmv) }\end{array}$ & $\mathrm{H}_{2} \mathrm{O}\left({ }^{\circ} \mathrm{C}\right)$ \\
\hline (17) & $\begin{array}{l}53.3 \\
54.2 \\
50.9 \\
\end{array}$ & $\begin{array}{l}1.36 \\
0.66 \\
0.51 \\
\end{array}$ & $\begin{array}{l}0.00 \\
0.00 \\
0.00\end{array}$ & $\begin{array}{l}1,940 \\
2,840 \\
2,880\end{array}$ & $\begin{array}{l}22.4 \\
22.4 \\
22.5 \\
\end{array}$ \\
\hline-17 & 52.8 & 0.84 & 0.00 & 2,553 & 22.4 \\
\hline$\left(21^{\prime}\right)$ & \multicolumn{5}{|c|}{ (Vacuum to High) } \\
\hline-21 & \multicolumn{5}{|c|}{ (Vacuum to High) } \\
\hline$\left(24^{\prime}\right)$ & $\begin{array}{l}20.0 \\
17.2 \\
15.9 \\
\end{array}$ & $\begin{array}{l}0.45 \\
0.42 \\
0.39 \\
\end{array}$ & $\begin{array}{l}0.00 \\
0.00 \\
0.00\end{array}$ & $\begin{array}{l}2,010 \\
2,190 \\
2,240\end{array}$ & $\begin{array}{l}23.2 \\
23.6 \\
24.1 \\
\end{array}$ \\
\hline-24 & 17.7 & 0.42 & 0.00 & 2,147 & 23.6 \\
\hline (29') & $\begin{array}{l}13.7 \\
11.9 \\
11.5 \\
\end{array}$ & $\begin{array}{l}0.26 \\
0.18 \\
0.22 \\
\end{array}$ & $\begin{array}{l}0.00 \\
0.00 \\
0.00\end{array}$ & $\begin{array}{l}1,390 \\
1,560 \\
1,590 \\
\end{array}$ & $\begin{array}{l}24.7 \\
24.7 \\
25.0 \\
\end{array}$ \\
\hline-29 & 12.4 & 0.22 & 0.00 & 1,513 & 24.8 \\
\hline$\left(34^{\prime}\right)$ & $\begin{array}{l}19.0 \\
16.2 \\
15.0 \\
\end{array}$ & $\begin{array}{l}0.39 \\
0.47 \\
0.47 \\
\end{array}$ & $\begin{array}{l}0.00 \\
0.00 \\
0.00 \\
\end{array}$ & $\begin{array}{l}1,460 \\
1,570 \\
1,590\end{array}$ & $\begin{array}{l}25.2 \\
25.4 \\
25.4 \\
\end{array}$ \\
\hline-34 & 16.7 & 0.44 & 0.00 & 1,540 & 25.3 \\
\hline$\left(39^{\prime}\right)$ & $\begin{array}{r}11.6 \\
9.7 \\
9.2 \\
\end{array}$ & $\begin{array}{l}0.38 \\
0.35 \\
0.15 \\
\end{array}$ & $\begin{array}{l}0.00 \\
0.00 \\
0.00 \\
\end{array}$ & $\begin{array}{l}1,240 \\
1,420 \\
1,410 \\
\end{array}$ & $\begin{array}{l}25.3 \\
25.4 \\
25.5 \\
\end{array}$ \\
\hline-39 & 10.2 & 0.29 & 0.00 & 1,357 & 25.4 \\
\hline$\left(44^{\prime}\right)$ & $\begin{array}{l}9.11 \\
8.55 \\
8.61 \\
\end{array}$ & $\begin{array}{l}0.26 \\
0.30 \\
0.31 \\
\end{array}$ & $\begin{array}{l}0.00 \\
0.00 \\
0.00\end{array}$ & $\begin{array}{l}1,470 \\
1,490 \\
1,490\end{array}$ & $\begin{array}{l}25.6 \\
25.8 \\
26.0 \\
\end{array}$ \\
\hline-44 & 8.76 & 0.29 & 0.00 & 1,483 & 25.8 \\
\hline$\left(50^{\prime \prime}\right)$ & $\begin{array}{r}12.8 \\
10.2 \\
9.8 \\
\end{array}$ & $\begin{array}{l}0.18 \\
0.26 \\
0.29 \\
\end{array}$ & $\begin{array}{l}0.00 \\
0.00 \\
0.00 \\
\end{array}$ & $\begin{array}{l}2,030 \\
2,000 \\
2,010 \\
\end{array}$ & $\begin{array}{l}26.1 \\
26.4 \\
26.5 \\
\end{array}$ \\
\hline-50 & 10.9 & 0.24 & 0.00 & 2,013 & 26.3 \\
\hline$\left(56^{\prime}\right)$ & $\begin{array}{l}13.4 \\
14.0 \\
13.8 \\
\end{array}$ & $\begin{array}{l}0.25 \\
0.34 \\
0.34 \\
\end{array}$ & $\begin{array}{l}0.00 \\
0.00 \\
0.00 \\
\end{array}$ & $\begin{array}{l}2,630 \\
1,910 \\
1,800 \\
\end{array}$ & $\begin{array}{l}26.7 \\
26.7 \\
26.7 \\
\end{array}$ \\
\hline-56 & 13.7 & 0.31 & 0.00 & 2,113 & 26.7 \\
\hline (61') & $\begin{array}{r}24.1 \\
8.7 \\
8.0 \\
\end{array}$ & $\begin{array}{l}0.00 \\
0.00 \\
0.00\end{array}$ & $\begin{array}{l}0.00 \\
0.00 \\
0.00\end{array}$ & $\begin{array}{l}4,740 \\
5,940 \\
5,780\end{array}$ & $\begin{array}{l}26.8 \\
27.0 \\
26.9 \\
\end{array}$ \\
\hline-61 & 13.6 & 0.00 & 0.00 & 5,487 & 26.9 \\
\hline
\end{tabular}


Table 10: Depth Discrete Soil Gas Concentrations Collected Prior to the Installation of MVE-17. (Samples collected and analyzed April 20, 1999)

\begin{tabular}{|c|c|c|c|c|c|}
\hline $\begin{array}{c}\text { Elevation } \\
\text { (depth) }\end{array}$ & $\begin{array}{c}\mathrm{PCE} \\
(\mathrm{ppmv})\end{array}$ & $\begin{array}{c}\text { TCE } \\
\text { (ppmv) }\end{array}$ & $\begin{array}{c}\mathrm{CCl}_{4} \\
\text { (ppmv) }\end{array}$ & $\begin{array}{c}\mathrm{CO}_{2} \\
\text { (ppmv) }\end{array}$ & $\mathrm{H}_{2} \mathrm{O}\left({ }^{\circ} \mathrm{C}\right)$ \\
\hline \multirow{5}{*}{$\left(20^{\prime}\right)$} & $4,690.0$ & 210.0 & 79.80 & 1,810 & 22.9 \\
\hline & $2,380.0$ & 85.7 & 0.00 & 61 & 22.8 \\
\hline & $5,860.0$ & 295.0 & 171.00 & 1,290 & 22.9 \\
\hline & $6,500.0$ & 302.0 & 244.00 & 1,380 & 23.1 \\
\hline & $6,850,0$ & 283.0 & 257.00 & 1,350 & 23.2 \\
\hline \multirow[t]{2}{*}{-20} & $5,256.0$ & 235.1 & 150.36 & 1,178 & 23.0 \\
\hline & $4,430.0$ & 51.2 & 69.40 & 657 & 25.9 \\
\hline \multirow[t]{3}{*}{ (25') } & $5,590.0$ & 164.0 & 159.00 & 905 & 26.2 \\
\hline & $6,050.0$ & 307.0 & 201.00 & 1,100 & 26.2 \\
\hline & $5,840,0$ & 339.0 & 181.00 & 1,110 & 26.1 \\
\hline-25 & $5,477.5$ & 215.3 & 152.60 & 943 & 26.1 \\
\hline \multirow{4}{*}{$\left(30^{\prime}\right)$} & $2,440.0$ & 52.0 & 0.00 & 1,670 & 27.2 \\
\hline & $2,620.0$ & 60.1 & 2.67 & 1,800 & 27.3 \\
\hline & $2,630.0$ & 61.8 & 2.89 & 1,830 & 27.5 \\
\hline & $2,620.0$ & 62.9 & 3.60 & 1,840 & 27.6 \\
\hline-30 & 2.577 .5 & 59.2 & 2.29 & 1,785 & 27.4 \\
\hline \multirow{4}{*}{$\left(35^{\prime}\right)$} & $1,550.0$ & 9.6 & 0.00 & 1,540 & 28.3 \\
\hline & $2,310.0$ & 12.6 & 0.00 & 1,860 & 28.4 \\
\hline & $2,540.0$ & 13.9 & 3.26 & 1,920 & 28.3 \\
\hline & $2,700.0$ & 15.2 & 6.02 & 1,960 & 28.4 \\
\hline-35 & $2,275.0$ & 12.8 & 2.32 & 1,820 & 28.4 \\
\hline \multirow{3}{*}{$\left(40^{\prime}\right)$} & 874.0 & 6.3 & 0.00 & 1,690 & 28.8 \\
\hline & 834.0 & 6.3 & 0.00 & 1,720 & 28.9 \\
\hline & 800.0 & 6.5 & 0.00 & 1,730 & 28.8 \\
\hline-40 & 836.0 & 6.4 & 0.00 & 1,713 & 28.8 \\
\hline
\end{tabular}


Table 11: Depth Discrete Soil Gas Concentrations Collected Prior to the Installation of MVE-18. (Samples collected and analyzed April 19, 1999)

\begin{tabular}{|c|c|c|c|c|c|}
\hline $\begin{array}{c}\text { Elevation } \\
\text { (depth) }\end{array}$ & $\begin{array}{c}\text { PCE } \\
\text { (ppmv) }\end{array}$ & $\begin{array}{c}\text { TCE } \\
\text { (ppmv) }\end{array}$ & $\begin{array}{c}\mathrm{CCl}_{4} \\
\text { (ppmv) }\end{array}$ & $\begin{array}{c}\mathrm{CO}_{2} \\
\text { (ppmv) }\end{array}$ & $\mathrm{H}_{2} \mathrm{O}\left({ }^{\circ} \mathrm{C}\right)$ \\
\hline \multirow{3}{*}{$\left(15^{\prime}\right)$} & 0.38 & 0.00 & 0.00 & 536 & 2.7 \\
\hline & 0.90 & 0.00 & 0.02 & 660 & 10.0 \\
\hline & 1.28 & 0.00 & 0.00 & 691 & 12.0 \\
\hline-15 & 0.85 & 0.00 & 0.01 & 629 & 8.2 \\
\hline \multirow{4}{*}{$\left(20^{\prime}\right)$} & 1.09 & 0.00 & 0.00 & 657 & 10.8 \\
\hline & 1.60 & 0.00 & 0.00 & 649 & 12.9 \\
\hline & 1.81 & 0.00 & 0.00 & 684 & 14.7 \\
\hline & 1.74 & 0.00 & 0.02 & 697 & 15.2 \\
\hline-20 & 1.56 & 0.00 & 0.01 & 672 & 13.4 \\
\hline \multirow{4}{*}{$\left(25^{\prime}\right)$} & 1.06 & 0.04 & 0.00 & 828 & 16.6 \\
\hline & 0.99 & 0.00 & 0.00 & 993 & 16.9 \\
\hline & 1.06 & 0.00 & 0.04 & 1,020 & 17.1 \\
\hline & 0.94 & 0.00 & 0.07 & 1,020 & 17.3 \\
\hline-25 & 1.01 & 0.01 & 0.03 & 965 & 17.0 \\
\hline \multirow{4}{*}{$\left(30^{\prime}\right)$} & 0.91 & 0.00 & 0.06 & 771 & 17.8 \\
\hline & 0.91 & 0.00 & 0.02 & 1,280 & 17.8 \\
\hline & 0.95 & 0.00 & 0.02 & 1,530 & 18.1 \\
\hline & 0.84 & 0.00 & 0.01 & 1,580 & 18.1 \\
\hline-30 & 0.90 & 0.00 & 0.03 & 1,290 & 18.0 \\
\hline \multirow{4}{*}{$\left(35^{\prime}\right)$} & 1.25 & 0.00 & 0.04 & 1,340 & 24.1 \\
\hline & 1.46 & 0.00 & 0.00 & 3,690 & 24.7 \\
\hline & 1.39 & 0.00 & 0.00 & 4,090 & 24.9 \\
\hline & 1.18 & 0.00 & 0.00 & 4,170 & 24.8 \\
\hline-35 & 1.32 & 0.00 & 0.01 & 3,323 & 24.6 \\
\hline \multirow{4}{*}{$\left(40^{\prime}\right)$} & 1.17 & 0.00 & 0.00 & 5,500 & 22.6 \\
\hline & 1.10 & 0.00 & 0.00 & 6,620 & 22.9 \\
\hline & 1.13 & 0.00 & 0.01 & 6,800 & 23.0 \\
\hline & 0.82 & 0.00 & 0.00 & 6,860 & 23.0 \\
\hline \multirow[t]{2}{*}{-40} & 1.06 & 0.00 & 0.00 & 6,445 & 22.9 \\
\hline & 1.04 & 0.00 & 0.10 & 1,640 & 21.8 \\
\hline \multirow[t]{3}{*}{$\left(45^{\prime}\right)$} & 0.98 & 0.00 & 0.00 & 4,230 & 21.3 \\
\hline & 1.15 & 0.00 & 0.09 & 6,040 & 21.0 \\
\hline & 1.19 & 0.00 & 0.11 & 7.100 & 20.8 \\
\hline-45 & 1.09 & 0.00 & 0.07 & 4,753 & 21.2 \\
\hline \multirow{4}{*}{$\left(50^{\prime}\right)$} & 1.81 & 0.00 & 0.00 & 4,650 & 19.8 \\
\hline & 1.85 & 0.00 & 0.00 & 6,020 & 20.0 \\
\hline & 1.65 & 0.00 & 0.00 & 6,540 & 20.2 \\
\hline & 1.68 & 0.00 & 0.00 & 6,780 & 19.9 \\
\hline-50 & 1.75 & 0.00 & 0.00 & 5,998 & 20.0 \\
\hline \multirow{4}{*}{$\left(55^{\prime}\right)$} & 2.02 & 0.00 & 0.00 & 4,140 & 19.5 \\
\hline & 1.98 & 0.00 & 0.00 & 7,100 & 19.7 \\
\hline & 1.91 & 0.00 & 0.00 & 7,510 & 19.7 \\
\hline & 1.82 & 0.00 & 0.00 & 7.770 & 19.8 \\
\hline-55 & 1.93 & 0.00 & 0.00 & 6,630 & 19.7 \\
\hline \multirow{3}{*}{$\left(60^{\prime}\right)$} & 1.37 & 0.00 & 0.00 & 8,700 & 19.3 \\
\hline & 1.34 & 0.00 & 0.00 & 9,270 & 19.4 \\
\hline & 1.25 & 0.00 & 0.00 & 9,400 & 19.1 \\
\hline-60 & 1.32 & 0.00 & 0.00 & 9,123 & 19.3 \\
\hline
\end{tabular}


Table 12: Depth Discrete Soil Gas Concentrations Collected Prior to the Installation of MVE-19. (Samples collected and analyzed April 20, 1999)

\begin{tabular}{|c|c|c|c|c|c|}
\hline $\begin{array}{l}\text { Elevation } \\
\text { (depth) }\end{array}$ & $\begin{array}{c}\text { PCE } \\
\text { (ppmv) }\end{array}$ & $\begin{array}{c}\text { TCE } \\
\text { (ppmv) }\end{array}$ & $\begin{array}{c}\mathrm{CCl}_{4} \\
\text { (ppmv) }\end{array}$ & $\begin{array}{c}\mathrm{CO}_{2} \\
\text { (ppmv) }\end{array}$ & $\mathrm{H}_{2} \mathrm{O}\left({ }^{\circ} \mathrm{C}\right)$ \\
\hline (15') & $\begin{array}{l}375.0 \\
219.0 \\
175.0 \\
\end{array}$ & $\begin{array}{r}10.5 \\
5.2 \\
3.8 \\
\end{array}$ & $\begin{array}{l}0.00 \\
0.00 \\
0.00 \\
\end{array}$ & $\begin{array}{l}593 \\
513 \\
506 \\
\end{array}$ & $\begin{array}{l}26.7 \\
27.0 \\
27.1 \\
\end{array}$ \\
\hline-15 & 256.3 & 6.5 & 0.00 & 537 & 26.9 \\
\hline$\left(20^{\prime}\right)$ & $\begin{array}{r}618.0 \\
907.0 \\
1,400.0 \\
1,370.0 \\
1,140.0 \\
\end{array}$ & $\begin{array}{r}13.5 \\
17.2 \\
24.0 \\
12.4 \\
9.9 \\
\end{array}$ & $\begin{array}{l}0.00 \\
0.00 \\
0.00 \\
0.00 \\
0.00 \\
\end{array}$ & $\begin{array}{l}1,100 \\
1,050 \\
1,260 \\
1,750 \\
1,720 \\
\end{array}$ & $\begin{array}{l}27.3 \\
27.5 \\
27.6 \\
27.5 \\
27.7 \\
\end{array}$ \\
\hline-20 & $1,087.0$ & 15.4 & 0.00 & 1,376 & 27.5 \\
\hline$\left(25^{\prime}\right)$ & $\begin{array}{l}150.0 \\
142.0 \\
137.0 \\
\end{array}$ & $\begin{array}{l}1.04 \\
0.83 \\
0.80 \\
\end{array}$ & $\begin{array}{l}0.00 \\
0.00 \\
0.00 \\
\end{array}$ & $\begin{array}{l}4,300 \\
4,340 \\
4,410 \\
\end{array}$ & $\begin{array}{l}29.5 \\
30.4 \\
30.5 \\
\end{array}$ \\
\hline-25 & 143.0 & 0.89 & 0.00 & 4,350 & 30.1 \\
\hline$\left(30^{\prime}\right)$ & $\begin{array}{r}117.0 \\
109.0 \\
97.4 \\
93.6 \\
\end{array}$ & $\begin{array}{l}2.38 \\
0.48 \\
0.11 \\
0.07 \\
\end{array}$ & $\begin{array}{l}0.00 \\
0.00 \\
0.00 \\
0.00 \\
\end{array}$ & $\begin{array}{r}559 \\
6,010 \\
6,780 \\
7,050 \\
\end{array}$ & $\begin{array}{l}30.1 \\
31.1 \\
31.2 \\
31.4 \\
\end{array}$ \\
\hline-30 & 104.3 & 0.76 & 0.00 & 5,100 & 31.0 \\
\hline$\left(35^{\prime}\right)$ & $\begin{array}{l}92.0 \\
87.5 \\
84.3 \\
\end{array}$ & $\begin{array}{l}0.00 \\
0.00 \\
0.00 \\
\end{array}$ & $\begin{array}{l}0.00 \\
0.00 \\
0.00 \\
\end{array}$ & $\begin{array}{l}9,250 \\
9,560 \\
9,680 \\
\end{array}$ & $\begin{array}{l}31.2 \\
31.3 \\
31.3 \\
\end{array}$ \\
\hline-35 & 87.9 & 0.00 & 0.00 & 9,497 & 31.3 \\
\hline$\left(40^{\prime}\right)$ & $\begin{array}{l}83.6 \\
77.2 \\
\end{array}$ & $\begin{array}{l}0.00 \\
0.00 \\
\end{array}$ & $\begin{array}{l}0.00 \\
0.00 \\
\end{array}$ & $\begin{array}{l}13,700 \\
14,900 \\
\end{array}$ & $\begin{array}{r}32.3 \\
32.5 \\
\end{array}$ \\
\hline-40 & 80.4 & 0.00 & 0.00 & 14,300 & 32.4 \\
\hline$\left(45^{\prime}\right)$ & $\begin{array}{l}69.5 \\
65.3 \\
62.3 \\
\end{array}$ & $\begin{array}{l}0.00 \\
0.00 \\
0.00 \\
\end{array}$ & $\begin{array}{l}0.00 \\
0.00 \\
0.00 \\
\end{array}$ & $\begin{array}{l}19,500 \\
19,500 \\
19,600 \\
\end{array}$ & $\begin{array}{l}30.2 \\
30.0 \\
29.7 \\
\end{array}$ \\
\hline-45 & 65.7 & 0.00 & 0.00 & 19,533 & 30.0 \\
\hline$\left(50^{\prime}\right)$ & $\begin{array}{l}97.8 \\
94.2 \\
91.1 \\
\end{array}$ & $\begin{array}{l}0.00 \\
0.00 \\
0.00 \\
\end{array}$ & $\begin{array}{l}0.00 \\
0.00 \\
0.00 \\
\end{array}$ & $\begin{array}{r}19,600 \\
21,200 \\
21,500 \\
\end{array}$ & $\begin{array}{l}28.9 \\
29.0 \\
28.5 \\
\end{array}$ \\
\hline-50 & 94.4 & 0.00 & 0.00 & 20.767 & 28.8 \\
\hline
\end{tabular}


Table 13: Depth Discrete Soil Gas Concentrations Collected Prior to the Installation of MVE-21. (Samples collected and analyzed April 21, 1999)

\begin{tabular}{|c|c|c|c|c|c|}
\hline $\begin{array}{c}\text { Elevation } \\
\text { (depth) }\end{array}$ & $\begin{array}{c}\mathrm{PCE} \\
\text { (ppmv) }\end{array}$ & $\begin{array}{c}\text { TCE } \\
\text { (ppmv) }\end{array}$ & $\begin{array}{c}\mathrm{CCl}_{4} \\
\text { (ppmv) }\end{array}$ & $\begin{array}{c}\mathrm{CO}_{2} \\
\text { (ppmv) }\end{array}$ & $\mathrm{H}_{2} \mathrm{O}\left({ }^{\circ} \mathrm{C}\right)$ \\
\hline \multirow{3}{*}{$\left(16^{\prime}\right)$} & 138.0 & 4.46 & 0.00 & 1,970 & 18.9 \\
\hline & 176.0 & 4.07 & 0.00 & 1,920 & 19.0 \\
\hline & 184.0 & 3.98 & 0.00 & 2,000 & 19.1 \\
\hline-16 & 166.0 & 4.17 & 0.00 & 1,963 & 19.0 \\
\hline \multirow{3}{*}{ (21') } & 59.2 & 0.46 & 0.00 & 2,040 & 19.6 \\
\hline & 39.3 & 0.00 & 0.00 & 3,490 & 19.9 \\
\hline & 32.9 & 0.27 & 0.00 & 3,540 & 20.2 \\
\hline-21 & 43.8 & 0.24 & 0.00 & 3,023 & 19.9 \\
\hline \multirow{3}{*}{$\left(26^{\prime}\right)$} & 56.1 & 0.48 & 0.00 & 3,240 & 20.8 \\
\hline & 43.7 & 0.46 & 0.00 & 3,190 & 20.9 \\
\hline & 38.5 & 0.42 & 0.00 & 3,080 & 21.1 \\
\hline-26 & 46.1 & 0.45 & 0.00 & 3,170 & 20.9 \\
\hline \multirow{3}{*}{$\left(31^{\prime}\right)$} & 18.9 & 0.15 & 0.00 & 3,540 & 21.6 \\
\hline & 17.2 & 0.02 & 0.00 & 3,600 & 21.7 \\
\hline & 16.7 & 0.15 & 0.00 & 3,640 & 22.3 \\
\hline-31 & 17.6 & 0.10 & 0.00 & 3,593 & 21.9 \\
\hline \multirow{3}{*}{$\left(36^{\prime}\right)$} & 16.1 & 0.49 & 0.00 & 1,100 & 22.3 \\
\hline & 16.1 & 0.51 & 0.00 & 1,240 & 22.6 \\
\hline & 15.8 & 0.47 & 0.00 & 1,350 & 22.8 \\
\hline-36 & 16.0 & 0.49 & 0.00 & 1,230 & 22.6 \\
\hline \multirow{3}{*}{$\left(41^{\prime}\right)$} & 14.8 & 0.58 & 0.00 & 1,220 & 23.2 \\
\hline & 13.1 & 0.59 & 0.00 & 1,280 & 23.5 \\
\hline & 12.8 & 0.58 & 0.00 & 1,280 & 23.8 \\
\hline \multirow[t]{2}{*}{-41} & 13.6 & 0.58 & 0.00 & 1,260 & 23.5 \\
\hline & 46.4 & 1.26 & 0.00 & 924 & 23.3 \\
\hline \multirow[t]{2}{*}{$\left(46^{\prime}\right)$} & 44.3 & 1.07 & 0.00 & 915 & 22.3 \\
\hline & 42.0 & 0.90 & 0.00 & 891 & 22.4 \\
\hline-46 & 44.2 & 1.08 & 0.00 & 910 & 22.7 \\
\hline \multirow{3}{*}{$\left(51^{\prime}\right)$} & 15.1 & 0.67 & 0.00 & 1,180 & 23.6 \\
\hline & 13.5 & 0.61 & 0.00 & 1,170 & 24.0 \\
\hline & 13.0 & 0.54 & 0.00 & 1,150 & 24.1 \\
\hline-51 & 13.9 & 0.61 & 0.00 & 1,167 & 23.9 \\
\hline \multirow{3}{*}{$\left(56^{\prime}\right)$} & 51.8 & 1.15 & 0.00 & 2,140 & 23.8 \\
\hline & 49.6 & 0.70 & 0.00 & 2,030 & 23.3 \\
\hline & 48.5 & 0.88 & 0.00 & 1,980 & 23.6 \\
\hline-56 & 50.0 & 0.91 & 0.00 & 2,050 & 23.6 \\
\hline \multirow{3}{*}{$\left(611^{\prime}\right)$} & 10.8 & 0.00 & 0.00 & 12,600 & 24.2 \\
\hline & 10.3 & 0.00 & 0.00 & 11,900 & 24.7 \\
\hline & 10.1 & 0.00 & 0.00 & 11,300 & 25.0 \\
\hline-61 & 10.4 & 0.00 & 0.00 & 11.933 & 24.6 \\
\hline \multirow{3}{*}{$\left(65^{\prime}\right)$} & 12.1 & 0.00 & 0.00 & 11,700 & 25.4 \\
\hline & 9.8 & 0.00 & 0.00 & 18,200 & 24.8 \\
\hline & 9.1 & 0.00 & 0.00 & 18,600 & 24.4 \\
\hline-65 & 10.3 & 0.00 & 0.00 & 16,167 & 24.9 \\
\hline
\end{tabular}


Table 14: Depth Discrete Soil Gas Concentrations Collected Prior to the Installation of MVE-22.

(Samples collected and analyzed April 20, 1999)

\begin{tabular}{|c|c|c|c|c|c|}
\hline $\begin{array}{c}\text { Elevation } \\
\text { (depth) }\end{array}$ & $\begin{array}{c}\text { PCE } \\
\text { (ppmv) }\end{array}$ & $\begin{array}{c}\text { TCE } \\
\text { (ppmv) }\end{array}$ & $\begin{array}{c}\mathrm{CCl}_{4} \\
\text { (ppmv) }\end{array}$ & $\begin{array}{c}\mathrm{CO}_{2} \\
\text { (ppmv) }\end{array}$ & $\mathrm{H}_{2} \mathrm{O}\left({ }^{\circ} \mathrm{C}\right)$ \\
\hline \multirow{3}{*}{$\left(16^{\prime}\right)$} & 354.0 & 3.76 & 0.00 & 2,510 & 24.5 \\
\hline & 266.0 & 2.56 & 0.00 & 2,260 & 24.5 \\
\hline & 232.0 & 1.94 & 0.00 & 2,520 & 24.7 \\
\hline-16 & 284.0 & 2.75 & 0.00 & 2,430 & 24.6 \\
\hline \multirow{3}{*}{$\left(21^{\prime}\right)$} & 66.1 & 0.62 & 0.00 & 1,310 & 25.5 \\
\hline & 56.0 & 0.62 & 0.00 & 1,690 & 24.4 \\
\hline & 50.0 & 0.51 & 0.00 & 1.710 & 25.4 \\
\hline-21 & 57.4 & 0.58 & 0.00 & 1.570 & 25.1 \\
\hline \multirow{3}{*}{$\left(26^{\prime}\right)$} & 104.0 & 1.13 & 0.00 & 1,270 & 24.7 \\
\hline & 85.8 & 0.87 & 0.00 & 1,390 & 24.5 \\
\hline & 81.5 & 0.87 & 0.00 & 1,410 & 24.3 \\
\hline-26 & 90.4 & 0.96 & 0.00 & 1,357 & 24.5 \\
\hline \multirow{3}{*}{$\left(31^{\prime}\right)$} & 49.3 & 0.52 & 0.00 & 1,190 & 23.7 \\
\hline & 41.0 & 0.34 & 0.00 & 1,500 & 23.8 \\
\hline & 38.1 & 0.31 & 0.00 & 1,540 & 23.8 \\
\hline-31 & 42.8 & 0.39 & 0.00 & 1,410 & 23.8 \\
\hline \multirow{3}{*}{$\left(36^{\prime}\right)$} & 41.6 & 0.39 & 0.00 & 1,180 & 25.3 \\
\hline & 35.8 & 0.34 & 0.00 & 1,450 & 25.7 \\
\hline & 33.3 & 0.34 & 0.00 & 1,450 & 26.2 \\
\hline-36 & 36.9 & 0.36 & 0.00 & 1,360 & 25.7 \\
\hline$\left(41^{\prime}\right)$ & \multicolumn{5}{|c|}{ (Vacuum to High) } \\
\hline-41 & \multicolumn{5}{|c|}{ (Vacuum to High) } \\
\hline \multirow{3}{*}{$\left(46^{\prime}\right)$} & 28.7 & 0.20 & 0.00 & 2,620 & 27.2 \\
\hline & 28.2 & 0.08 & 0.00 & 2,630 & 27.0 \\
\hline & 27.2 & 0.04 & 0.00 & 2.660 & 26.9 \\
\hline-46 & 28.0 & 0.11 & 0.00 & 2,637 & 27.0 \\
\hline \multirow{3}{*}{$\left(511^{\prime}\right)$} & 33.4 & 0.00 & 0.00 & 8,560 & 27.1 \\
\hline & 31.2 & 0.00 & 0.00 & 12,400 & 27.1 \\
\hline & 29.5 & 0.00 & 0.00 & 13,200 & 26.8 \\
\hline \multirow[t]{2}{*}{-51} & 31.4 & 0.00 & 0.00 & 11,387 & 27.0 \\
\hline & 27.2 & 0.00 & 0.00 & 19,000 & 27.0 \\
\hline \multirow[t]{2}{*}{$\left(56^{\prime}\right)$} & 24.5 & 0.00 & 0.00 & 22,600 & 27.0 \\
\hline & 23.6 & 0.00 & 0.00 & 26,800 & 26.8 \\
\hline-56 & 25.1 & 0.00 & 0.00 & 22,800 & 26.9 \\
\hline \multirow{3}{*}{$\left(61^{\prime}\right)$} & 27.3 & 0.00 & 0.00 & 5,160 & 27.0 \\
\hline & 27.1 & 0.00 & 0.00 & 15,700 & 27.3 \\
\hline & 25.0 & 0.00 & 0.00 & 22,600 & 27.0 \\
\hline-61 & 26.5 & 0.00 & 0.00 & 14.487 & 27.1 \\
\hline$\left(66^{\prime}\right)$ & \multicolumn{5}{|c|}{ (Vacuum to High) } \\
\hline \multicolumn{2}{|l|}{-66} & \multicolumn{3}{|c|}{ (Vacuum to High) } & \\
\hline
\end{tabular}


Table 15: Confirmatory GC Analysis for Soil-Gas Samples Collected at the Headwaters of the A-014 Outfall.

\begin{tabular}{|ccrrrr|}
\hline Location & $\begin{array}{c}\text { Elevation } \\
\text { (depth) }\end{array}$ & $\begin{array}{c}\mathrm{CCl}_{4} \\
\text { (ppmv) }\end{array}$ & $\begin{array}{c}\text { PCE } \\
\text { (ppmv) }\end{array}$ & $\begin{array}{c}\text { TCA } \\
\text { (ppmv) }\end{array}$ & \multicolumn{1}{c|}{$\begin{array}{c}\text { TCE } \\
\text { (ppmv) }\end{array}$} \\
\hline MVE-17 & $\left(20^{\prime}\right)$ & 0.07 & 9682.35 & 74.61 & 170.76 \\
& $\left(30^{\prime}\right)$ & 0.01 & 2262.53 & 17.17 & 63.63 \\
\hline MVE-19 & $\left(20^{\prime}\right)$ & ND & 812.98 & 0.45 & 10.49 \\
& $\left(45^{\prime}\right)$ & ND & 51.53 & 0.05 & 0.86 \\
\hline
\end{tabular}

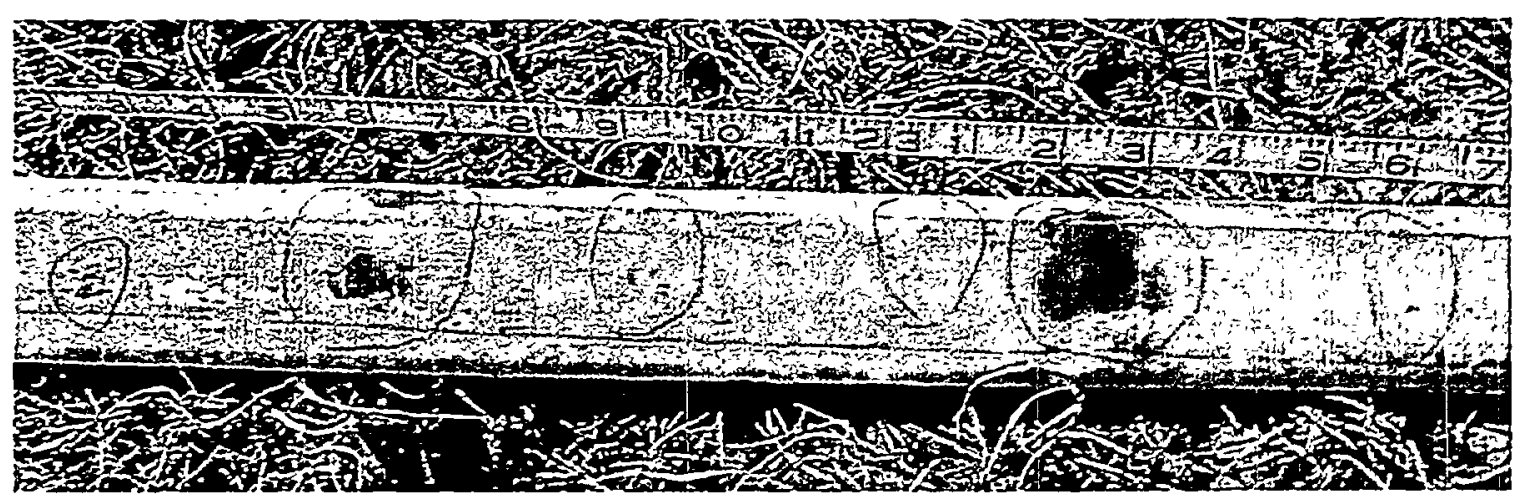

Figure 8: Subsurface DNAPL Detected with Ribbon NAPL Sampler eployed at HFM-3/MVE 17 near the headwaters of A-014 Outfall. 


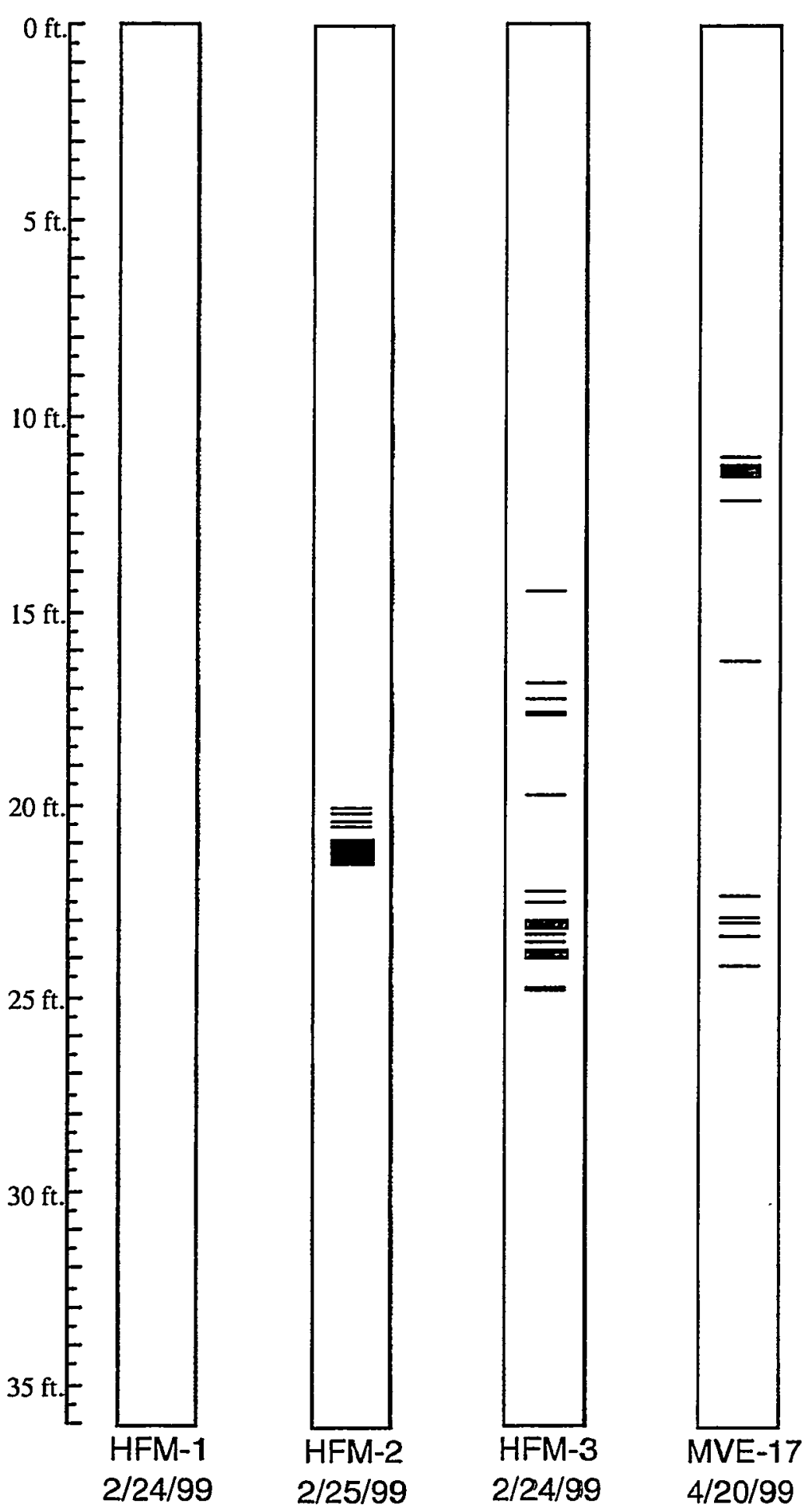

Figure 9: Comparison of Results from Ribbon NAPL Sampler Deployed at HFM-1, HFM-2, HFM-3, and MVE-17. 


\section{Expansion of 782-3M Extraction Wells}

As presented previously, active vadose zone and groundwater remediation activities are ongoing at the A014 Outfall. Soil vapor extraction using $782-3 \mathrm{M}$ is being used to address vadose zone contamination in the vicinity of the outfall. This unit is connected to three vadose zone extraction wells that are manually adjusted along with make-up air such that effluent concentrations are keep below permitted levels. As presented in Figure 4, the inlet concentrations associated with this unit have steadily declined since extraction well redevelopment occurred in 1997. This decline represents the removal of solvents that are within the radius of influence of the operating extraction wells. Previous investigations (Jarosch et.al. 1998) estimated the radius of influence at MVE-9 based on pressure drawdown at vadose probes MVC- 2 and MVC-3. The results for MVE- 9 from this investigation ranged from 42 feet to 280 feet and are summarized in Table 16. These results indicate that the radius of influence increases with depth to a maximum value corresponding with the depth of the extraction screen. The variation of radius of influence with depth is presented in Figure 10. Due to the variation of radius of influence with depth and the geologic conditions of the vadose zone in A/M Area, the existing soil vapor extraction system at the A-014 Outfall has had limited effectiveness in providing remediation for the shallow sediments near the headwaters.

In order to address the DNAPL that was identified in the shallow sediments near the headwaters of the A014 outfall, these CPT borings were completed as vadose zone wells. Screen zones were selected to target regions of highest contamination so that the wells can serve as additional extraction points for the $782-3 \mathrm{M}$ system. Although EPA guidelines (EPA, 1992) indicate that the geologic conditions and soil permeability will limit the effectiveness of SVE in these zones, the presence and existence of permitted remediation infrastructure serves to justify the installation of the additional wells. The fine-grained nature and aspect of the sediments that serve to hold the DNAPL in the vadose zone by capillary forces also limit the permeability of the sediments and results in a decrease in the effectiveness of SVE. Although the performance is expected to be limited, removal of small quantities of soil-gas at or near the vapor pressure of solvents involved can result in a significant increase in mass removed.

The additional wells were installed in the boreholes using direct-push techniques. Wells that were positioned in, or adjacent, to those areas considered to contain DNAPL were constructed of Schedule 5304 stainless steel. Wells that were located in regions not considered to contain DNAPL were constructed of Schedule 40 PVC. The installation of stainless steel wells in regions containing DNAPL will prevent any deterioration and distortion that typically occurs with PVC wells installed in DNAPL regions. An additional benefit of stainless steel construction is that should SVE be ineffective, the design and construction should be acceptable for use with enhanced remediation technologies, i.e. steam injection, insitu heating, or enhanced oxidation/dissolution through chemical injection. Well screens for the stainless steel wells used a 0.01 inch slot mini-louver designed screen oriented to minimize clogging during installation. Screen sections for the PVC wells conventional PVC slotted screens with a 0.01 inch slot. Screen length for all wells was 10 foot and all wells were completed with either a 2 or 5 foot sump. To ensure an adequate surface seal, all of the wells were sealed with a grout slurry and a concrete pad was installed. Well construction and location information is summarized in Table 17 and well construction diagrams for all wells installed are included in Appendix B.

\section{Recommendations and Conclusions}

The results from these characterization activities indicate that DNAPL is present in the shallow (10-25 foot below land surface) vadose zone near the headwaters of the A-014 Outfall. The available information indicates that although the DNAPL is within the radius of influence of ongoing remediation systems, the interval is not adequately being addressed due to the interbedded nature of the sediments of the vadose zone in $\mathrm{A} / \mathrm{M}$ Area. To address this, a series of vertical extraction wells were installed for connection and configuration into the existing, permitted soil vapor extraction system located at the outfall. It is postulated that the increased infiltration associated with the headwaters of the outfall may have had an effect on the distribution and subsequent removal of DNAPL in the vicinity. Additional information is needed on the possible effects of this additional infiltration and on the effects of co-disposed liquids released to the outfall. 
Table 16: Permeability and Radius of Influence (RO) Estimates for Vertical Extraction Well MVE-9 at the A014 Outfall. (Adopted from Jarosch et. al. 1998)

\begin{tabular}{|l|c|c|c|c|}
\hline $\begin{array}{l}\text { Observation } \\
\text { Wells }\end{array}$ & $\begin{array}{c}\text { Average Depth } \\
\text { (Feet BLS) }\end{array}$ & $\begin{array}{c}\text { Radial } \\
\text { Permeability } \\
\text { (Darcy) }\end{array}$ & $\begin{array}{c}\text { Flow Rate } \\
\text { (scfm) }\end{array}$ & $\begin{array}{c}\text { Radius of } \\
\text { Influence } \\
\text { (feet) }\end{array}$ \\
\hline MVC-2A/3A & 107 & 5.7 & 92 & 42 \\
\cline { 4 - 5 } & & & 236 & $>133$ \\
\cline { 4 - 5 } & & & 405 & $>133$ \\
\hline MVC-2B/3B & 71.5 & 26.5 & 92 & 66 \\
\cline { 4 - 5 } & & & 236 & 191 \\
\cline { 4 - 5 } & & & 405 & 280 \\
\hline MVC-2C/3C & 51.5 & 25.8 & 92 & 38 \\
\cline { 4 - 5 } & & & 236 & 144 \\
\cline { 4 - 5 } & & & 405 & 228 \\
\hline
\end{tabular}

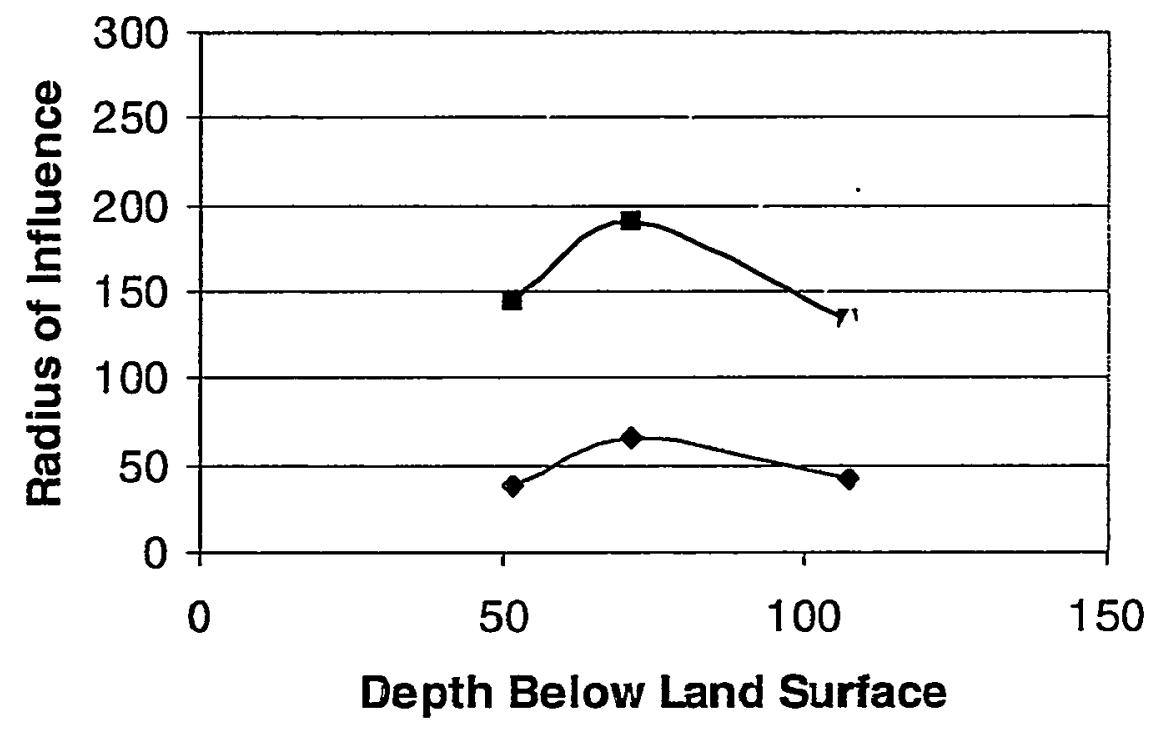

$$
\rightarrow-92 \mathrm{scfm} \rightarrow-236 \mathrm{scfm} \quad 405 \mathrm{scfm}
$$

Figure 10: Effect of Subsurface Depth on the Measured Radius of Influence at MVE-9. (Data Adopted from Jarosch et. al. 1998) 
Table 17: Summary of Information for Vadose Zone Wells installed at the A-014 Outfall.

\begin{tabular}{|c|c|c|c|l|}
\hline Well ID & SRS Easting & SRS Northing & $\begin{array}{c}\text { Top of Screen } \\
- \\
\text { Bottom of Screen }\end{array}$ & \multicolumn{1}{|c|}{$\begin{array}{c}\text { Material of } \\
\text { Construction }\end{array}$} \\
\hline MVE-13 & 49997 & 102014 & $17-27$ feet & $\begin{array}{l}\text { Schedule 5 304 SS with } \\
\text { Mini-Louver Screen }\end{array}$ \\
\hline MVE-14 & 50044 & 102032 & $17-27$ feet & $\begin{array}{l}\text { Schedule 5 304 SS with } \\
\text { Mini-Louver Screen }\end{array}$ \\
\hline MVE-15 & 50097 & 102050 & $15-25$ feet & $\begin{array}{l}\text { Schedule 5 304 SS with } \\
\text { Mini-Louver Screen }\end{array}$ \\
\hline MVE-16 & 49976 & 101974 & $16-26$ feet & $\begin{array}{l}\text { Schedule 5 304 SS with } \\
\text { Mini-Louver Screen }\end{array}$ \\
\hline MVE-17 & 50016 & 101989 & $16-26$ feet & $\begin{array}{l}\text { Schedule 5 304 SS with } \\
\text { Mini-Louver Screen }\end{array}$ \\
\hline MVE-18 & 50063 & 102006 & $16-26$ feet & $\begin{array}{l}\text { Schedule 5 304 SS with } \\
\text { Mini-Louver Screen }\end{array}$ \\
\hline MVE-19 & 50112 & 102019 & $14-24$ feet & $\begin{array}{l}\text { Schedule 5 304 SS with } \\
\text { Mini-Louver Screen }\end{array}$ \\
\hline MVE-21 & 50068 & 101913 & $14-24$ feet & $\begin{array}{l}\text { Schedule 40 PVC with } \\
\text { Slotted Screen }\end{array}$ \\
\hline MVE-22 & 50101 & 101875 & $14-24$ feet & $\begin{array}{l}\text { Schedule 40 PVC with } \\
\text { Slotted Screen }\end{array}$ \\
\hline
\end{tabular}




\section{References}

Aadland, R. K, Gellisci, J. A., and Thayer, P. A. (1995). Hydrogeologic Framework of West-Central South Carolina. Technical Report 5, State of South Carolina Department of Natural Resources Water Resources Division, Aiken, South Carolina, 29808.

CH2M Hill, (1990). A/M Area Vadose Zone Characterization Report (U). WSRC-RP-90-1335. Prepared by CH2M Hill for Westinghouse Savannah River Company, Aiken, SC 29808.

Christensen, E. J. and Brendell, C. (1982). Chlorinated Solvent Releases to M-Area Process Sewer. Technical Report DPST-81-0968, E. I. duPont de Nemours \& Co., Savannah River Laboratory, Aiken, South Carolina 29808.

Cohen, R. M. and Mercer, J. W. (1993). DNAPL Site Evaluation. CRC Press, 2000 Corporate Blvd., N.W., Boca Raton, Florida 33431.

Eddy, C. A., Looney, B. B., Dougherty, J. M., Hazen, T. C., and Kaback, D. S., 1991. Characterization of the Geology, Geochemistry, Hydrology, and Microbiology of the In Situ Air Stripping Demonstration Site at the Savannah River Site, WSRC-RD-91-21, Westinghouse Savannah River Company, Aiken, SC 29808.

EPA (1992) A Technology Assessment of Soil Vapor Extraction and Air Sparging. EPA/600/R-92/173, September 1992. United States Environmental Protection Agency, Office of Research and Development, Washington, DC 20460.

Haselow, J. S., Beaudoin, C. M., and Schreuder, P. J. (1991). Zone of Capture Analysis for the A/M Area of the Savannah River Site (U). Technical Report WSRC-RP-91-1216, Westinghouse Savannah River Company, Aiken, South Carolina 29808.

Jackson, D. G. and Aleman, S. E. (1995). Three Dimensional Zone of Capture Analysis for the A/M Area (U). Technical Report WSRC-RP-95-0843, Westinghouse Savannah River Company, Aiken, South Carolina 29808.

Jackson, D. G., Payne, T. H., Looney, B. B., and Rossabi, J. (1996). Estimating the Extent and Thickness of DNAPL within the A/M Area of the Savannah River Site (U). Technical Report WSRC-RP-960574, Westinghouse Savannah River Company, Aiken, South Carolina 29808.

Jarosch, T. R., Jackson, D. G., Looney, B. B., Jerome, K. M, Riha, B. D., Rossabi, J., Van Pelt, R.S., and J.J. Kupar. (1998). A/M Area Vadose Zone Monitoring Plan (U). WSRC-RP-98-00146, Westinghouse Savannah River Company, Aiken, SC 29808.

Jerome, K. M, Riha, B. D., and B. B. Looney. (1997) Final Report For Demonstration of In Situ Oxidation of DNAPL Using the Geo-Cleanse Technology (U). Technical Report WSRC-TR-97-00283, Westinghouse Savannah River Company, Aiken, South Carolina 29808.

Jerome, K. M., Noonkester, J. V., Looney, B. B., Simmons, J. L., and S. L. Baxley. (1998). AVM Area DNAPL Characterization Report For Cores Collected in FY97 and $1 Q 98$ and $2 Q 98$ (U). Technical Report WSRC-TR-98-00296, Issued October 1, 1998, Revision 0. Westinghouse Savannah River Company, Aiken, SC 29808.

Looney, B. B., Rossabi, J. R., and Tuck, D. M., 1992. Assessing DNAPL contamination, A/M-Area, Savannah River Site: Phase I Results (U). WSRC-RP-92-1302, Westinghouse Savannah River Company, Aiken, SC 29808.

Marine, I. W. and Bledsoe, H. W. (1984). Supplemental Technical Summary M-Area Groundwater Investigation. Technical Report DPSTD-84-112, E. I. duPont de Nemours \& Co., Savannah River Laboratory, Aiken, South Carolina 29808.

Parker, W.H., Smits, A.D., Harris, M.K., Jackson, D.G., and K.L. Hawkins (1999). Baseline Mapping Study of the Steed Pond Aquifer and Vadose Zone Beneath AM Area, Savannah River Site, Aiken, South Carolina $(U)$. WSRC-TR-99-00295 August 1999 Westinghouse Savannah River Company, Aiken, South Carolina 29808. 
Pankow, J. F. and Cherry, J. A. (1996). Dense Chlorinated Solvents and other DNAPLs in Groundwater. Waterloo Press, P.O. Box 91399, Portland, Oregon 97291-1399.

S.S. Papadopulos \& Associates (1987). Evaluation of the E_ectiveness of the M-Area Extraction System September 1985 to October 1986. Prepared for E.I. DuPont deNemours \& Company by S.S. Papadopulos \& Associates. Document Available from Savannah River Site, Aiken, South Carolina, Document SRT-EST-97-187. 


\section{Appendices}

Appendix A: Cone Penetrometer Logs for Boring at A-014 Outfall

Appendix B: Well Construction Records for Extraction Wells MVE-13 through MVE-22. 
Appendix A: Cone Penetrometer Logs for Boring at A-014 Outfall 


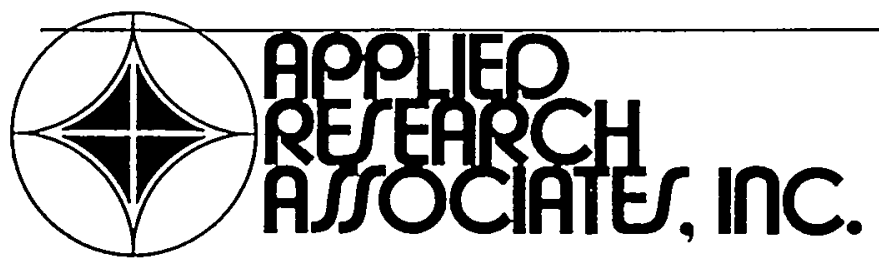

Engineering and Applied Science

April 16, 1999

ATTN : Brian Riha

WSRC

Bldg. 704D

Aiken, SC 29808

Dear Mr. Riha:

Applied Research Associates, Inc. is pleased to submit the data reflecting the field effort performed on January 17 - 24, 1999, in Cape Canaveral; January 25 - 29 in Jacksonville, FL; February 22 - March 5, at Savannah River Site. The cone penetrometer tests conducted under this project are summarized in Table 1.

The information provided for each cone penetration test includes corrected tip stress, sleeve stress, friction ratio, pore pressure, and resistivity data. The computer disks provide the ECP files that contain the plotted data in ASCII format. The information contained on the data sheets and computer disks shall be considered as final and correct.

Please feel free to call us if you have any questions regarding the enclosed information.

Sincerely,

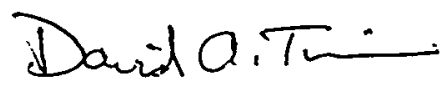

David A. Timian, P.E.

DAT:bef

Principal Engineer

d:14892\4892_cvrltr_a.doc 
Table 1 Summary of cone penetrometer data (SCAPS : Jan.-Feb., 1999)

\begin{tabular}{|l|c|c|c|l|}
\hline \multicolumn{1}{|c|}{ Site } & Test Id. & $\begin{array}{c}\text { Date of } \\
\text { Test }\end{array}$ & ARA Filename & \multicolumn{1}{|c|}{ Comments } \\
\hline \hline Cape Canaveral & LC34-B47 & $01 / 20 / 99$ & $520 \mathrm{J903M}$ & cone became wet at $11.2 \mathrm{ft}$ \\
\hline \multirow{5}{*}{ Jacksonville } & SAGE1A & $01 / 26 / 99$ & $526 \mathrm{~J} 903$ & resistivity data only \\
\cline { 2 - 5 } & SAGE2A & $01 / 26 / 99$ & $526 \mathrm{~J} 906$ & sleeve acquisition problem \\
\cline { 2 - 5 } & SAGE2B & $01 / 26 / 99$ & $526 \mathrm{~J} 908 \mathrm{~B}$ & \\
\cline { 2 - 5 } & SAGE3 & $01 / 27 / 99$ & $527 \mathrm{~J} 903$ & \\
\hline \multirow{3}{*}{ SRS } & HFM-1 & $02 / 25 / 99$ & $525 \mathrm{F902}$ & resistivity problem below 45 ft \\
\cline { 2 - 5 } & HFM-2 & $03 / 05 / 99$ & $505 \mathrm{M} 901$ & \\
\cline { 2 - 5 } & HFM-3 & $02 / 26 / 99$ & $526 \mathrm{~F} 901$ & \\
\hline
\end{tabular}



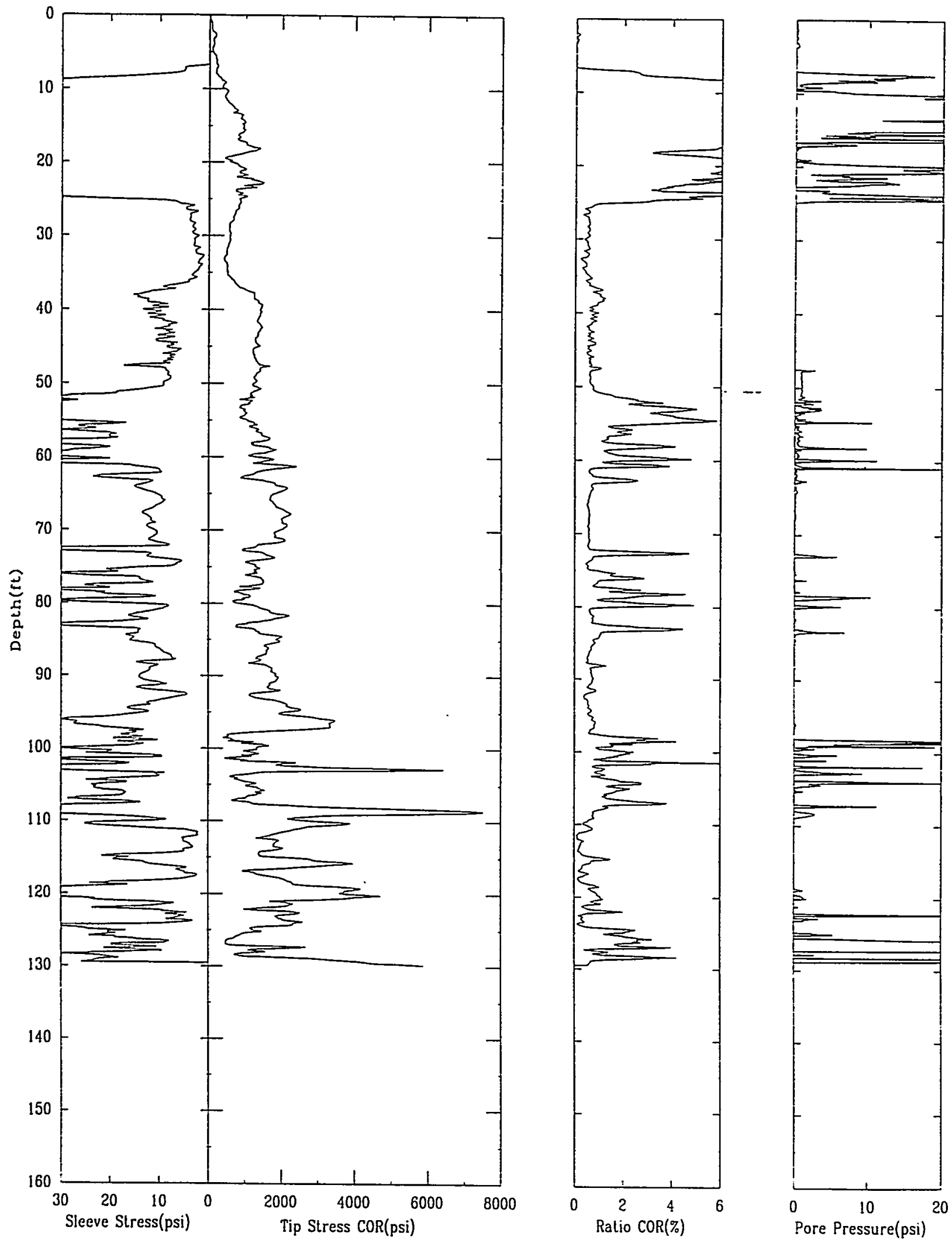
HFM-1

APPLIED RESEARCH ASSOCIATES, INC.

$02 / 24 / 99$

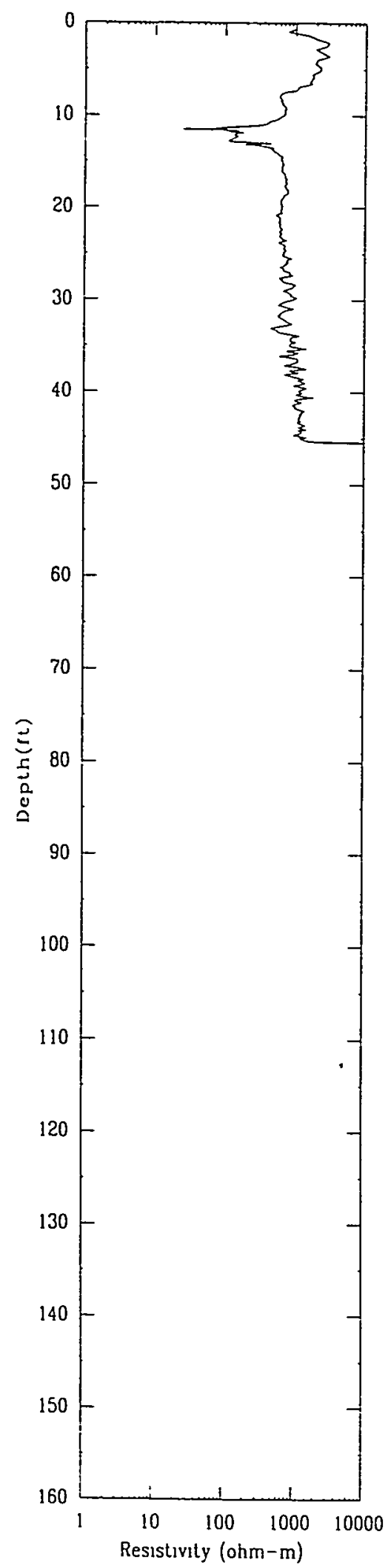


HFM-2

APPLIED RESEARCH ASSOCIATES, INC.

03/05/99

(repush)
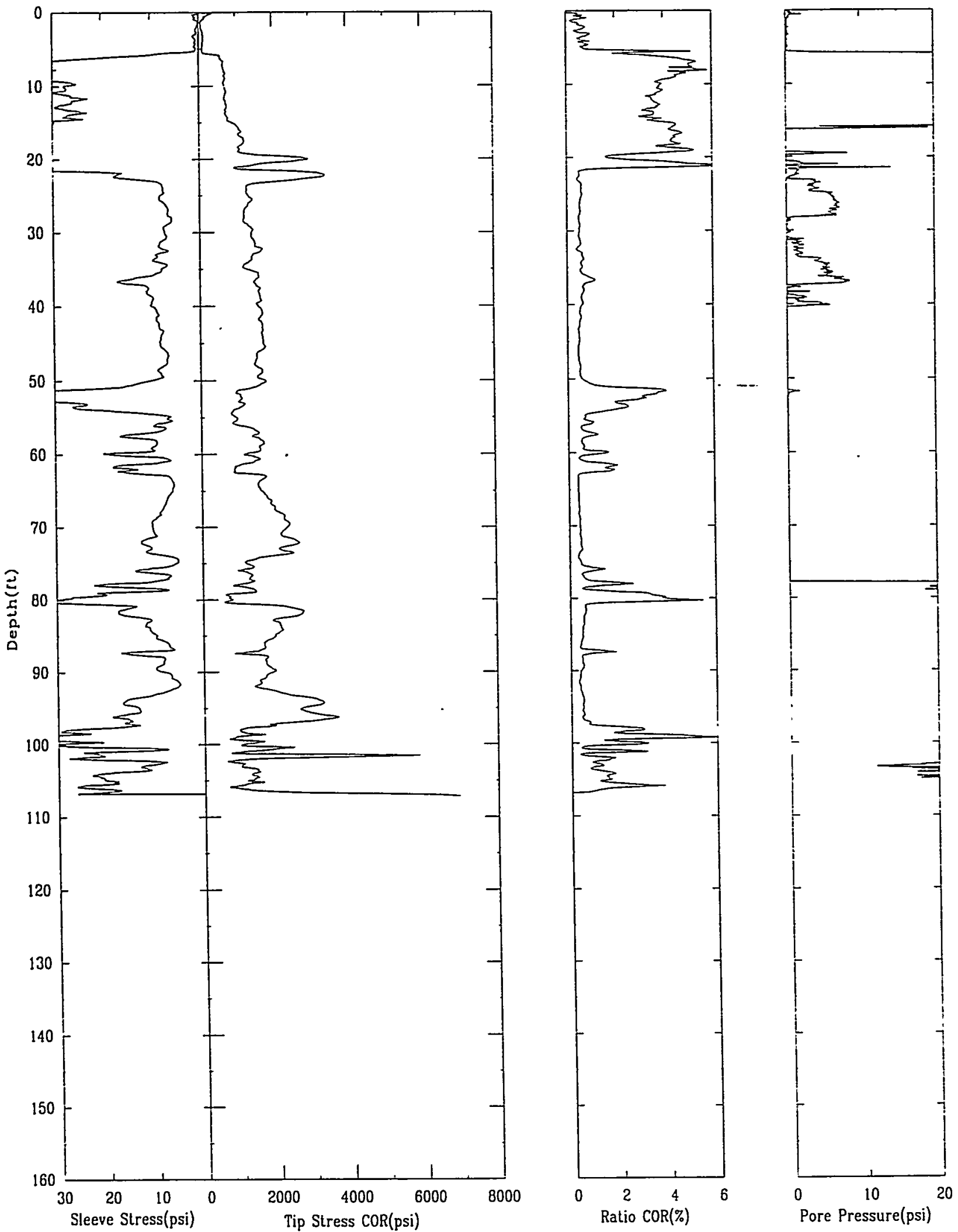

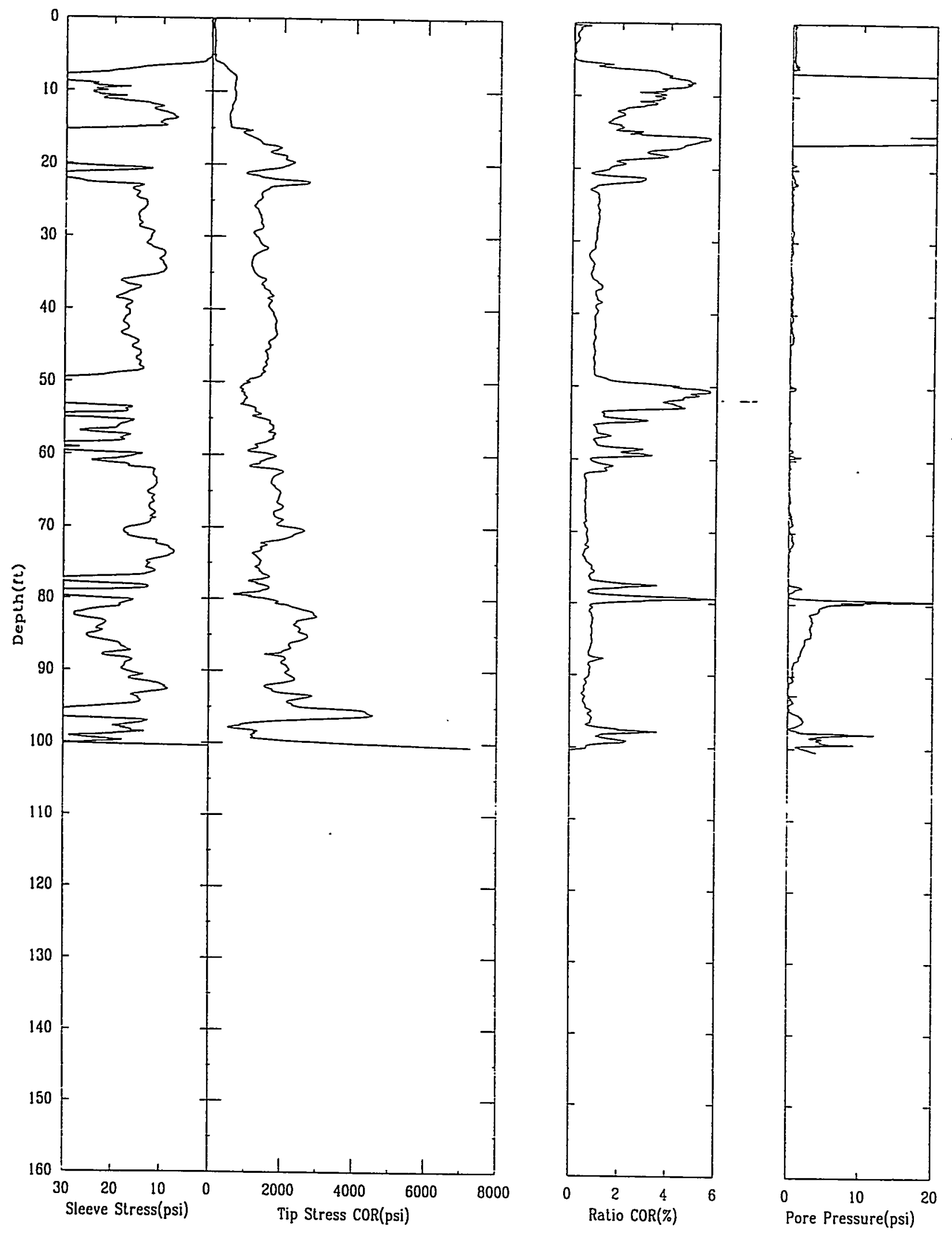
HFM-3

APPLIED RESEARCH ASSOCIATES, INC.

$02 / 26 / 99$

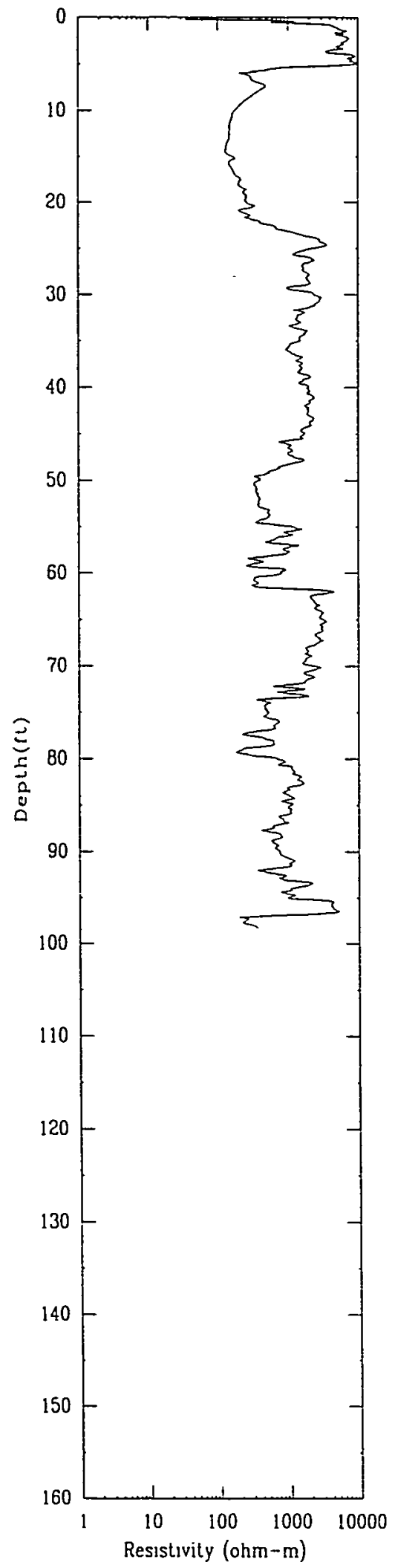

File 526F901.ECP 


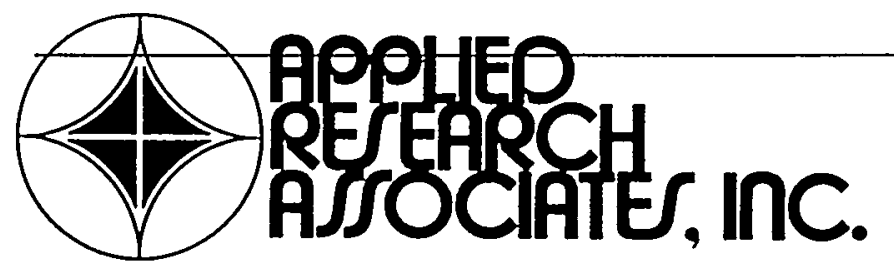

Engineering and Applied Science

December 29, 1999

Brian Riha

WSRC

Bldg. 704D

Aiken, SC 29808

Dear Mr. Riha:

Attached is the cone penetrometer data from the 16 test locations conducted at the Savannah River Site A-14 Outfall, Aiken, SC. WSRC Subcontract No. AC 07756N. The cone penetrometer tests conducted are summarized in Table 1.

The information provided for the cone penetration test includes: corrected tip stress, sleeve stress, friction ratio, pore pressure, soil resistivity, and soil classification based on friction ratio. The computer disks provide the ECP files that contain the plotted data in ASCII format.

Please feel free to call us if you have any questions regarding the enclosed information.

Sincerely,

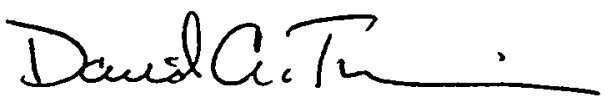

David A. Timian, P.E.

DAT:bef

Principal Engineer

d:14892_SCAPSI4892_cvmpt.doc 


\begin{tabular}{|l|c|c|c|c|c|}
\hline Test ID & Filename & $\begin{array}{c}\text { Type of } \\
\text { Test }\end{array}$ & $\begin{array}{c}\text { Date of } \\
\text { Test }\end{array}$ & $\begin{array}{c}\text { Maximum } \\
\text { Depth } \\
\text { (ft) }\end{array}$ & $\begin{array}{c}\text { G.W.T. } \\
\text { Depth } \\
\text { (ft) }\end{array}$ \\
\hline \hline MVE-13 & $520 a 901$ & R/P-CPT & $4 / 20 / 99$ & 43.0 & N/A \\
\hline MVE-14 & $519 a 903$ & R/P-CPT & $4 / 19 / 99$ & 63.0 & N/A \\
\hline MVE-15 & $519 a 901$ & R/P-CPT & $4 / 19 / 99$ & 60.3 & N/A \\
\hline MVE-16 & $521 a 903$ & R/P-CPT & $4 / 21 / 99$ & 64.0 & N/A \\
\hline MVE-17 & $520 a 903$ & R/P-CPT & $4 / 20 / 99$ & 43.0 & N/A \\
\hline MVE-18 & $519 a 905$ & R/P-CPT & $4 / 19 / 99$ & 63.0 & N/A \\
\hline MVE-19 & $520 a 905$ & R/P-CPT & $4 / 20 / 99$ & 53.0 & N/A \\
\hline MVE-21 & $521 a 901$ & R/P-CPT & $4 / 21 / 99$ & 68.5 & N/A \\
\hline MVE-22 & $520 a 907$ & R/P-CPT & $4 / 20 / 99$ & 68.0 & N/A \\
\hline
\end{tabular}




\section{MVE-13 APPLIED RESEARCH ASSOCIATES, INC. $\quad 04 / 20 / 99$}
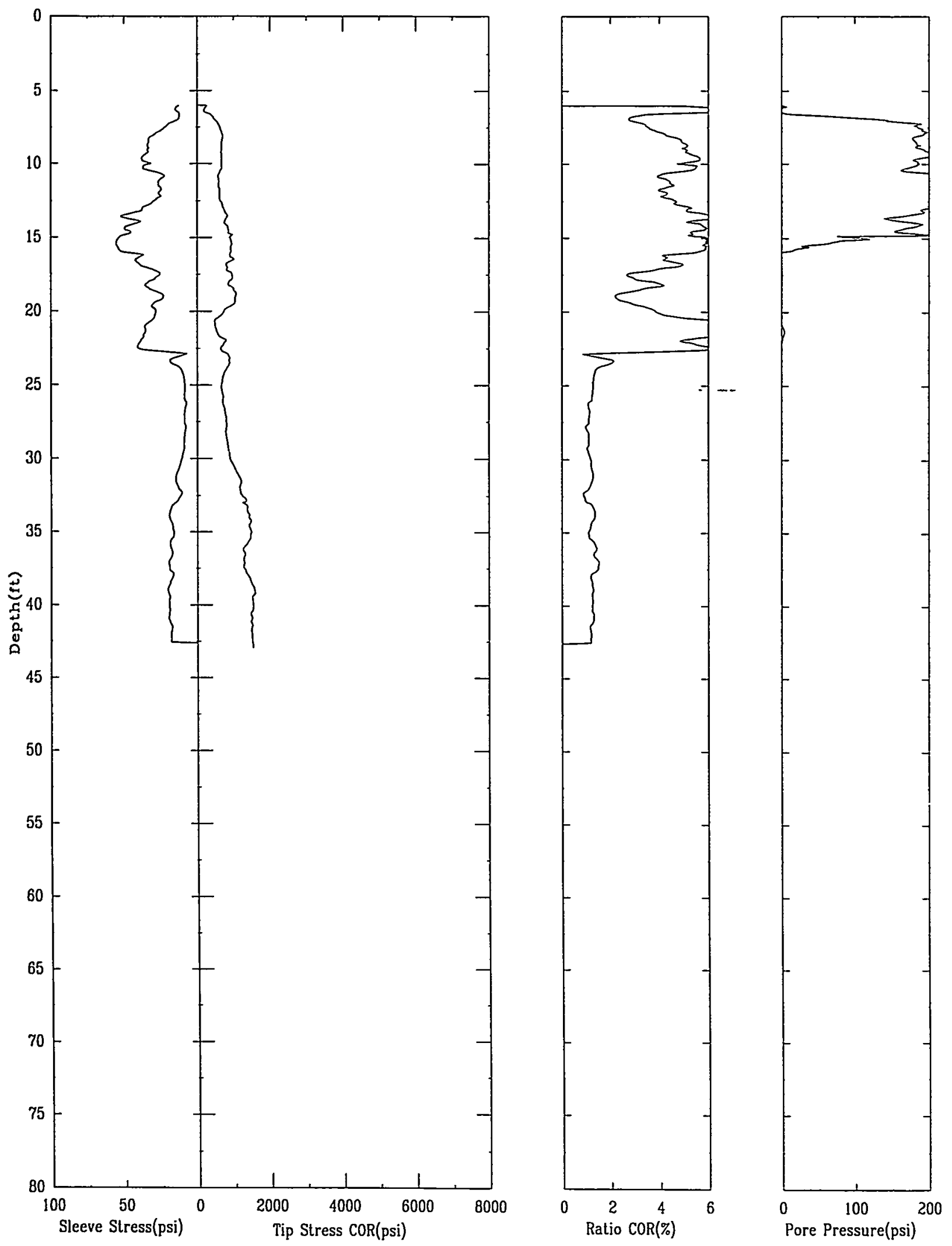


\section{MVE-13 APPLIED RESEARCH ASSOCIATES, INC. 04/20/99}

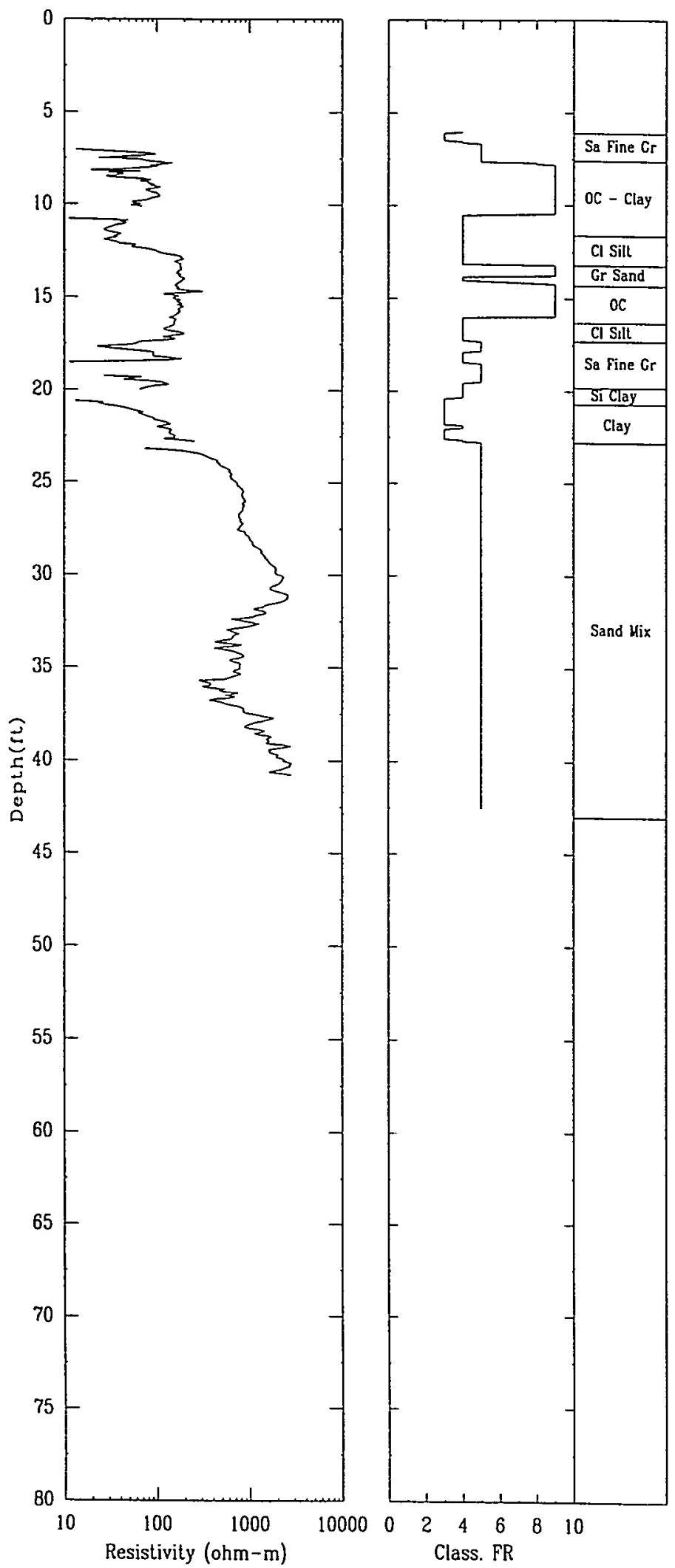


MVE-14 APPLIED RESEARCH ASSOCIATES, INC.

$04 / 19 / 99$
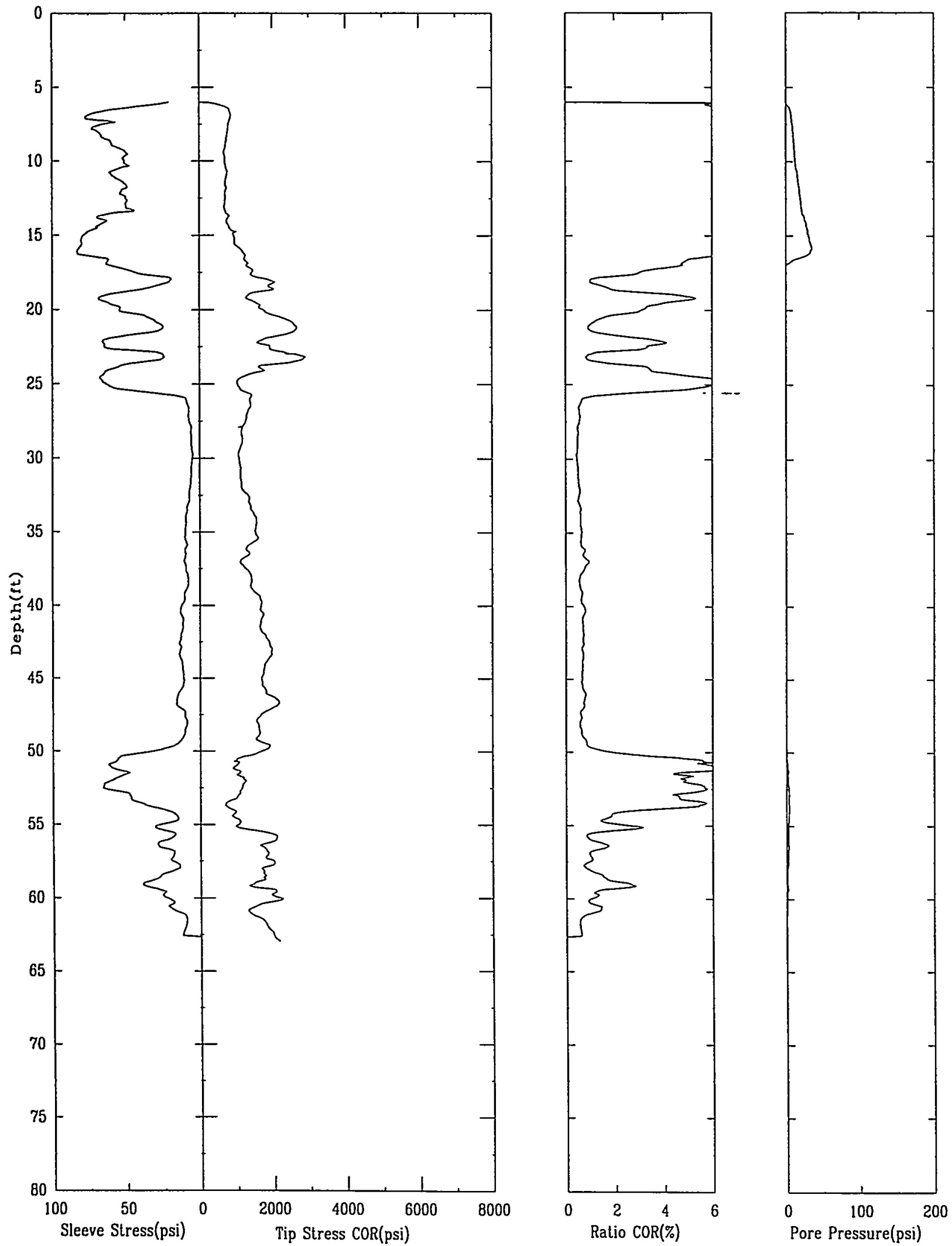

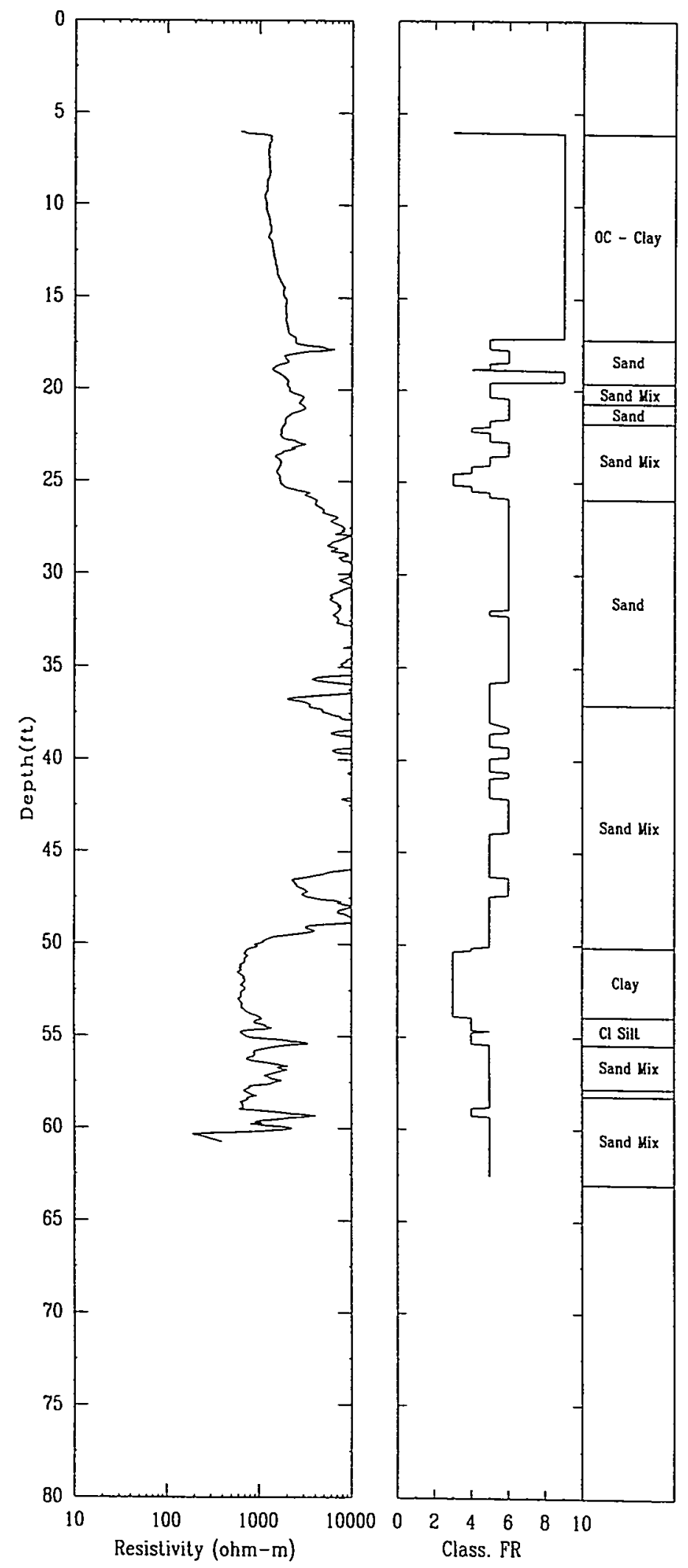

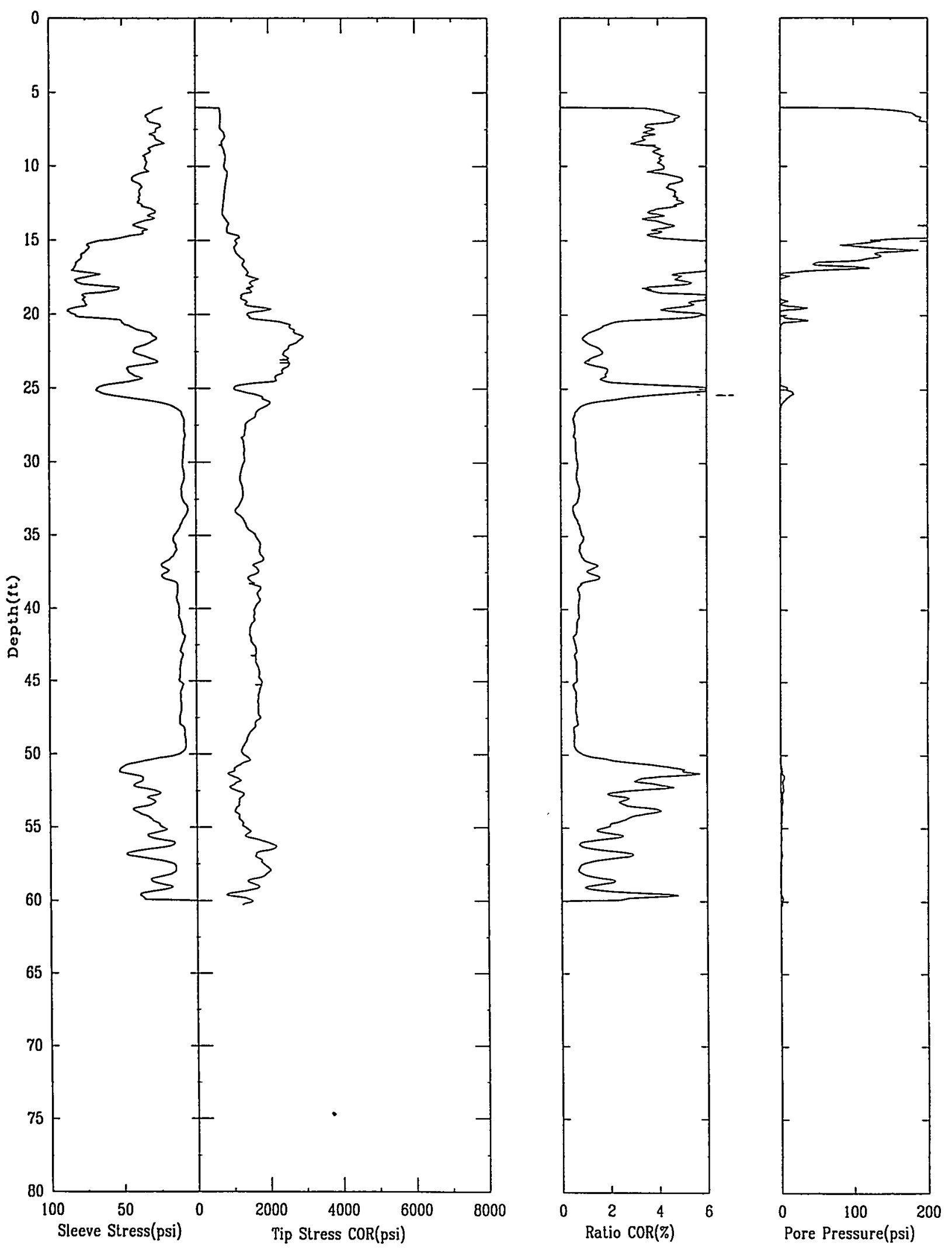


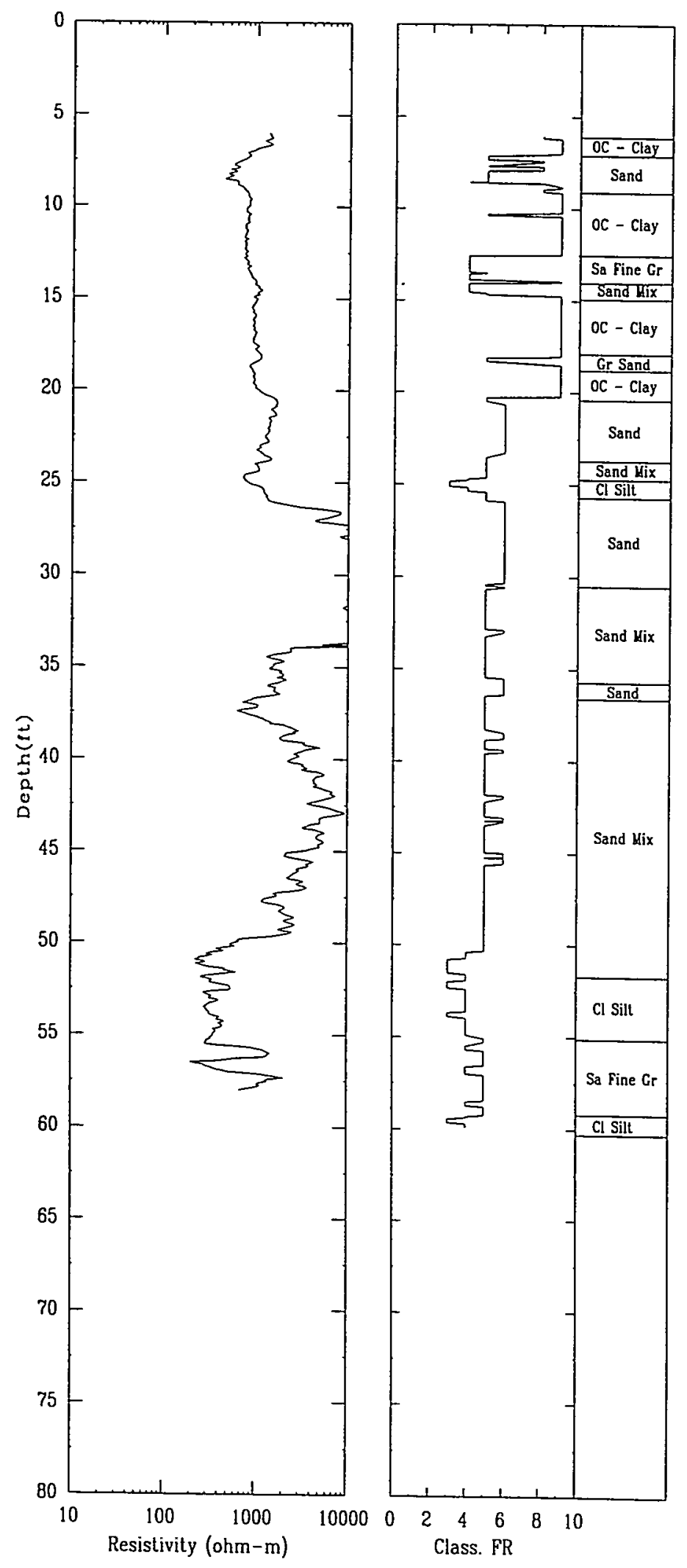



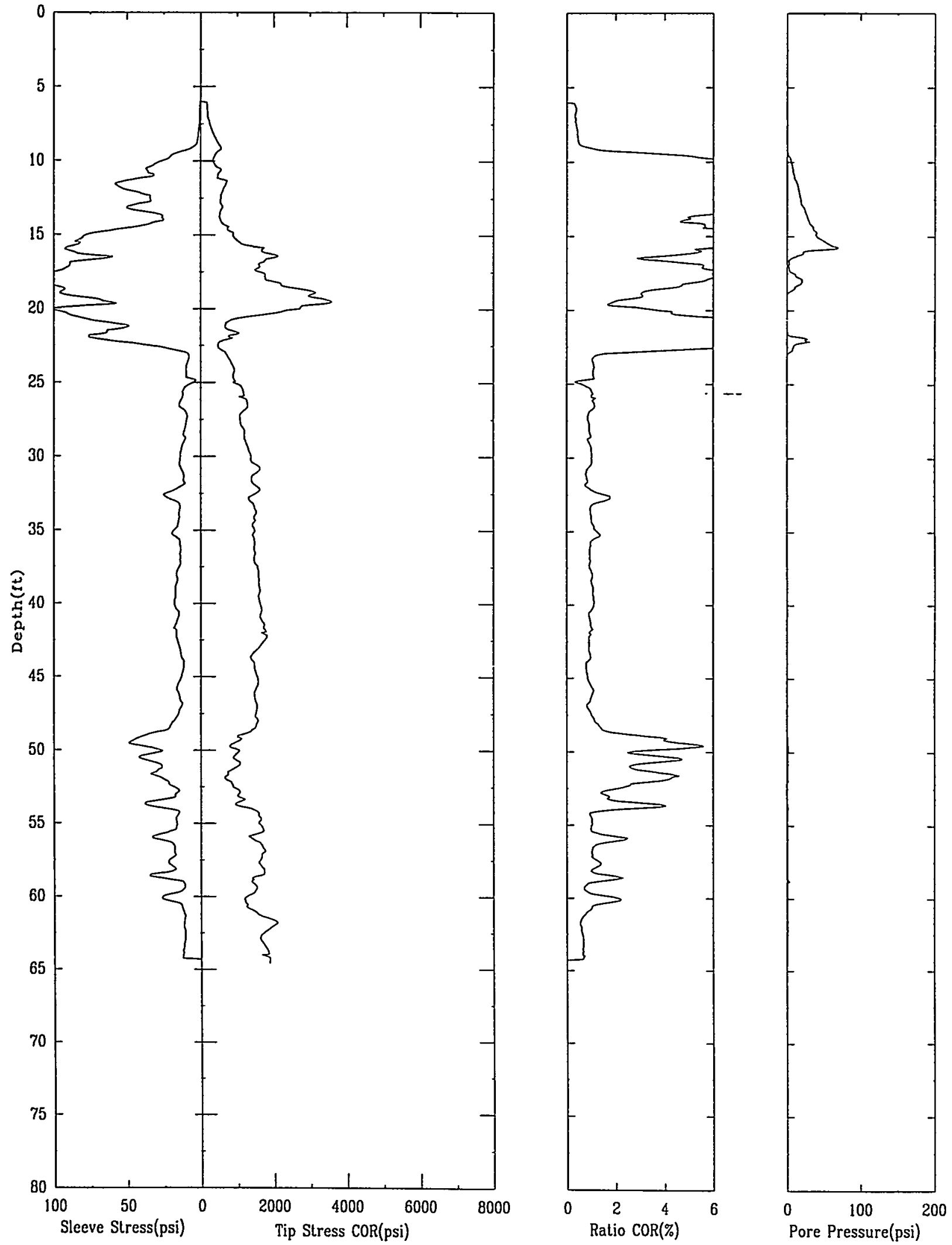


\section{MVE-16 APPLIED RESEARCH ASSOCIATES, INC. 04/21/99}

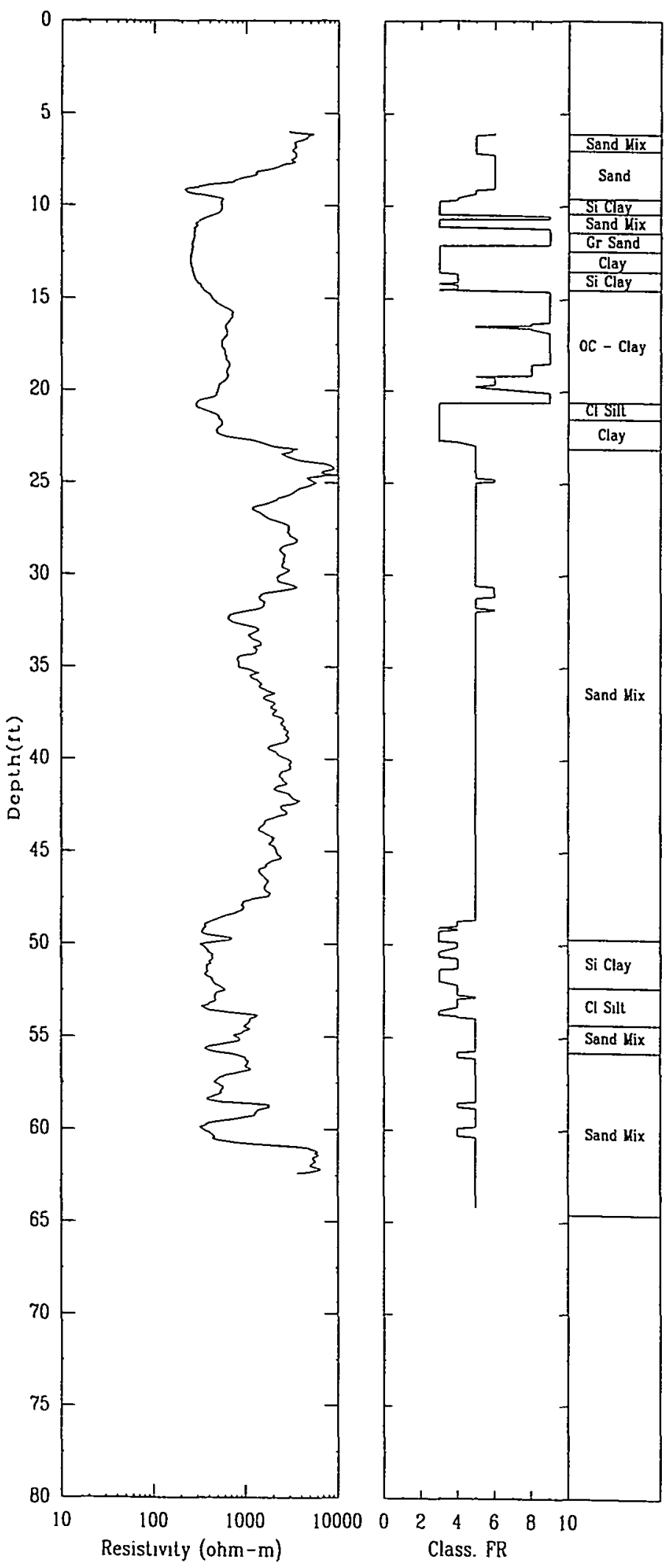



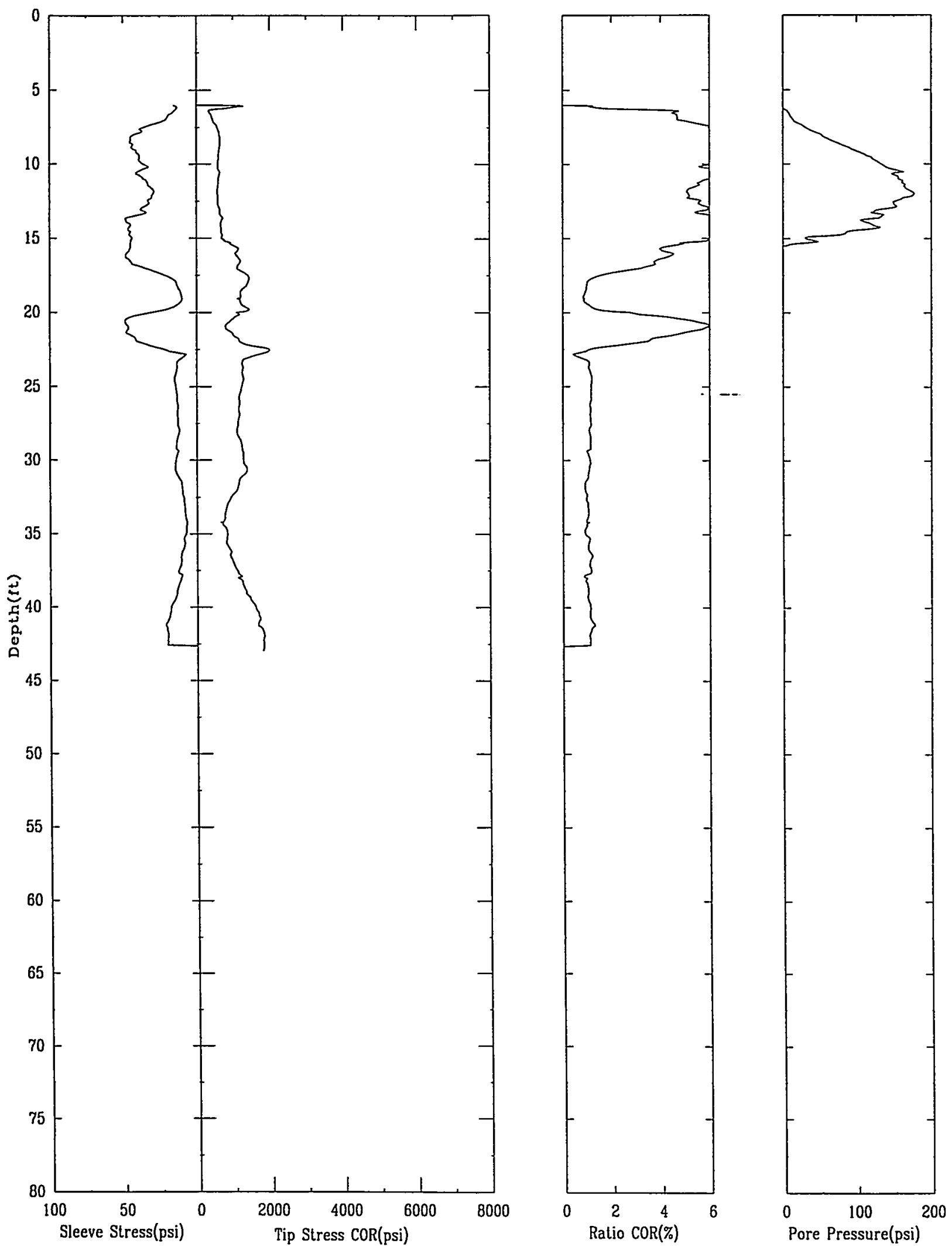


\section{MVE-17}

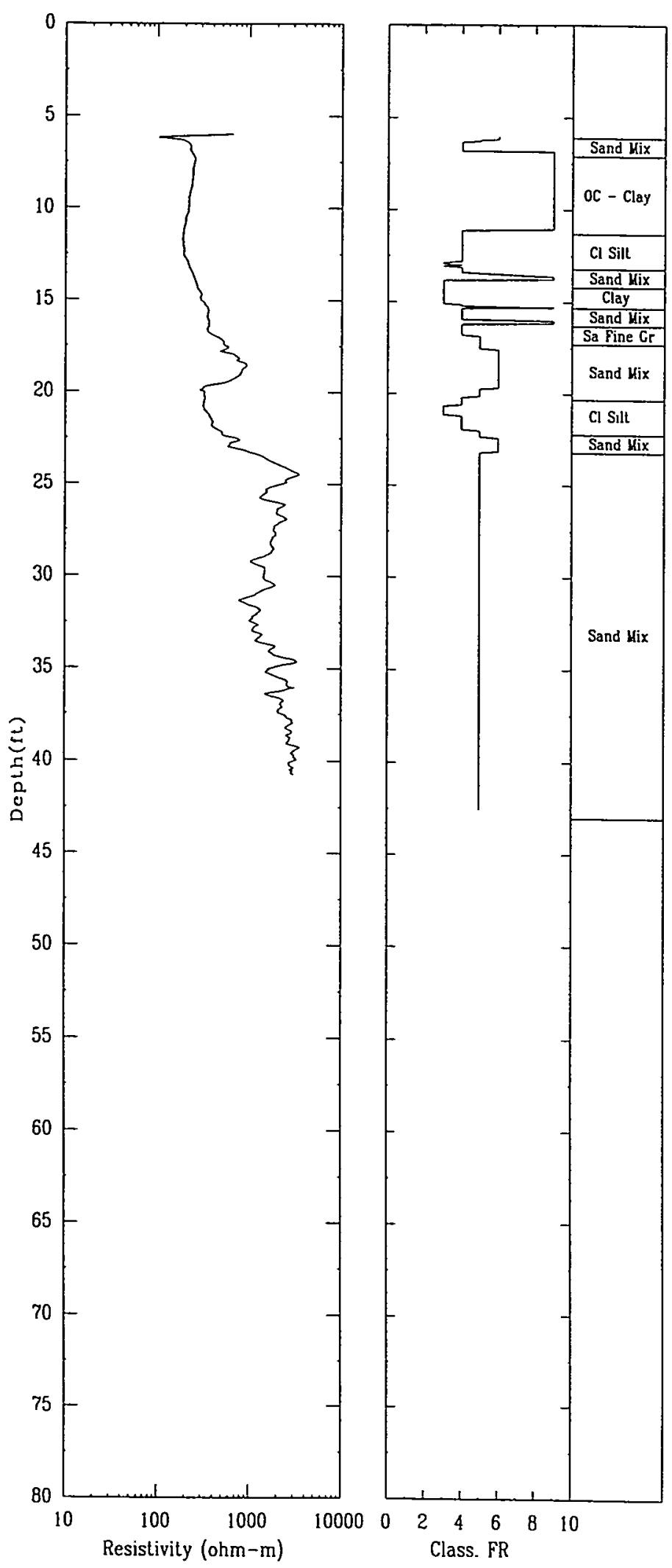


MVE-18

APPLIED RESEARCH ASSOCIATES, INC.

$04 / 19 / 99$
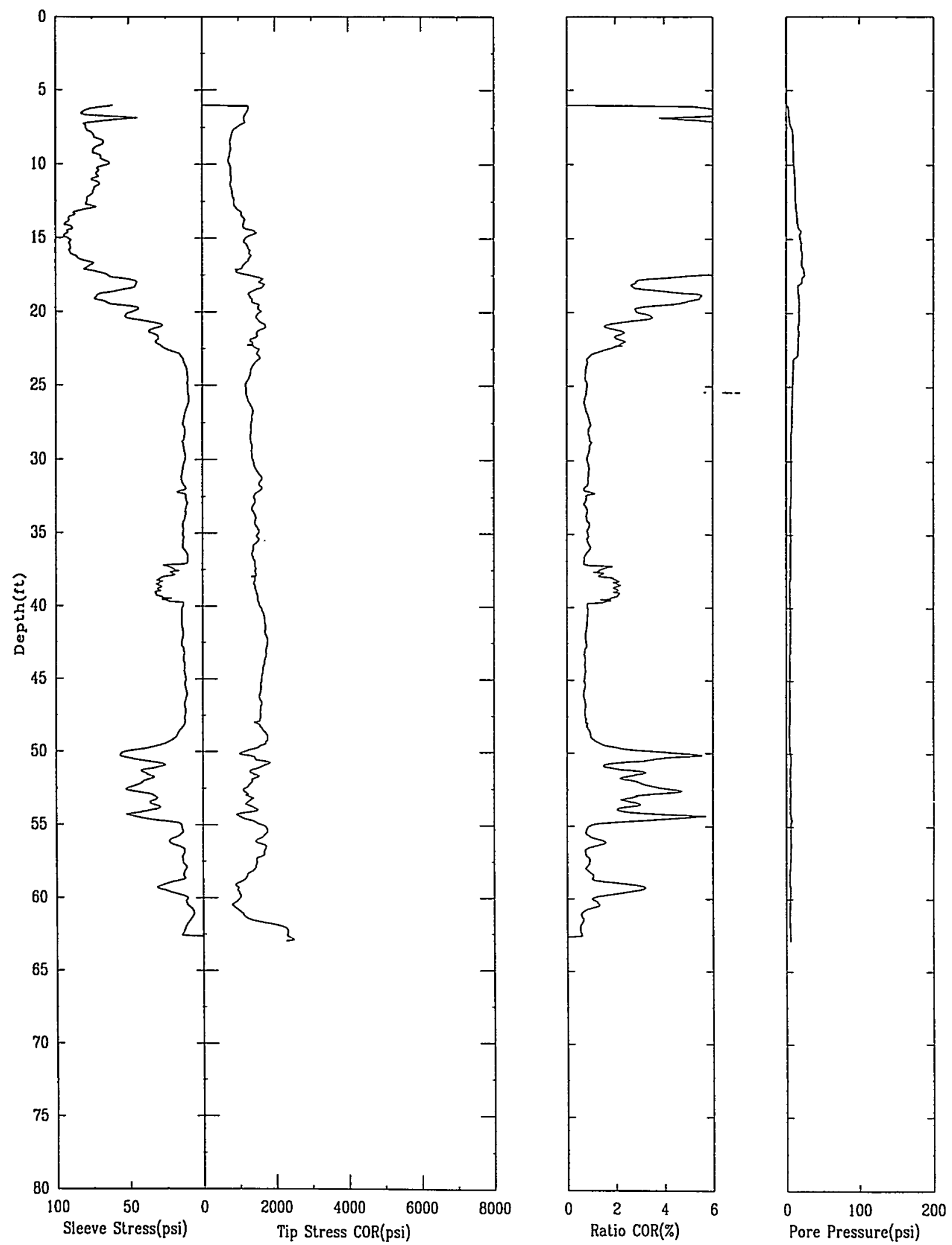


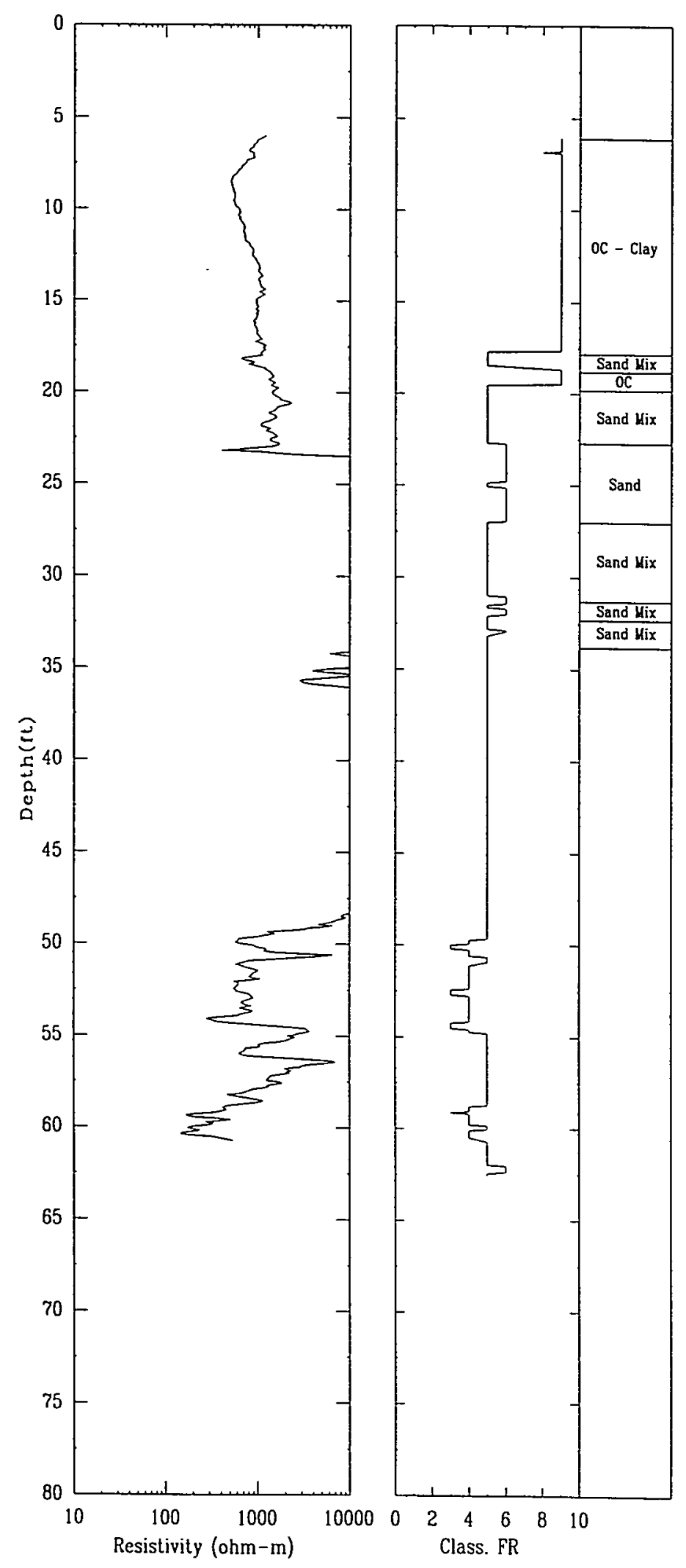



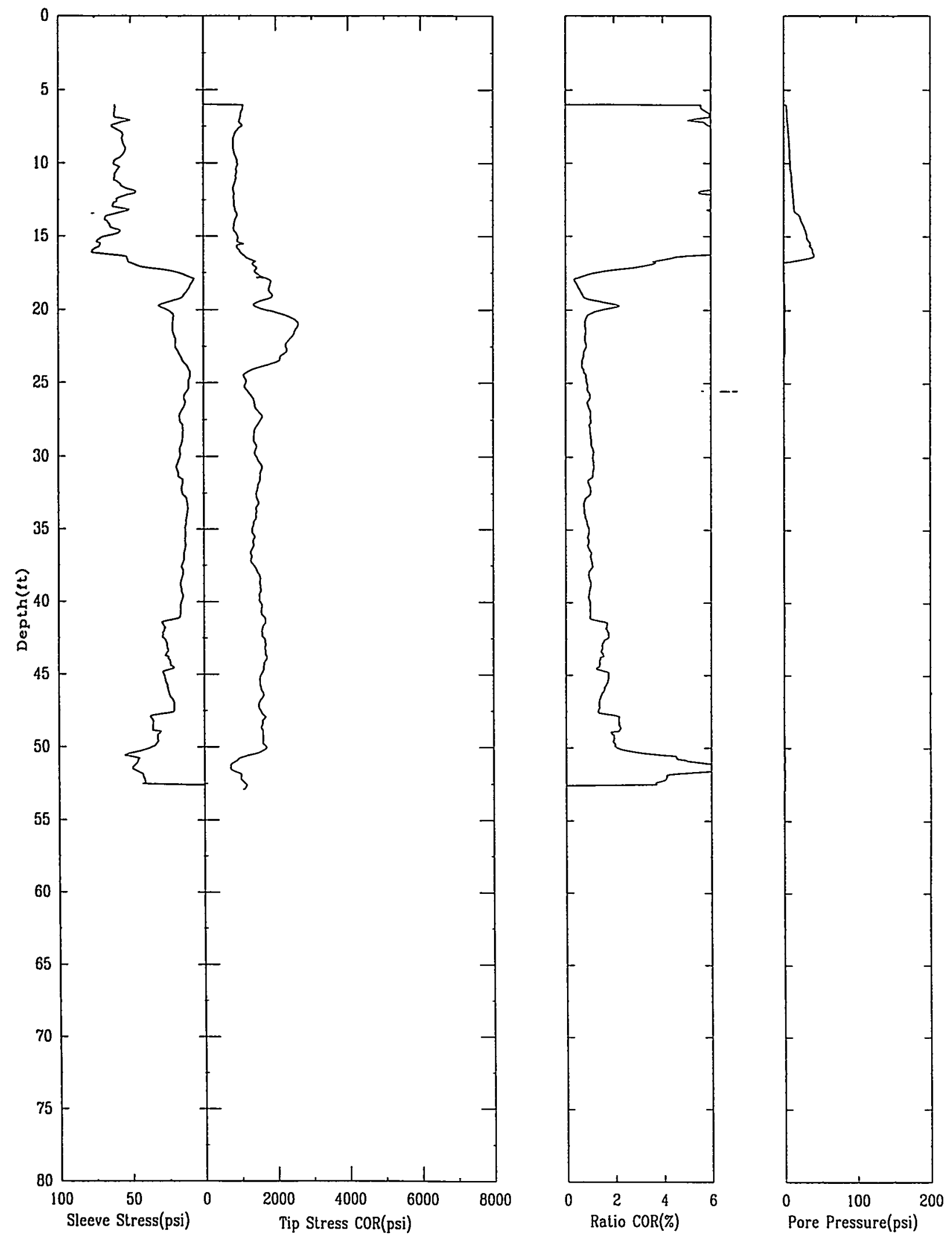
MVE-19

APPLIED RESEARCH ASSOCIATES, INC.

$04 / 20 / 99$

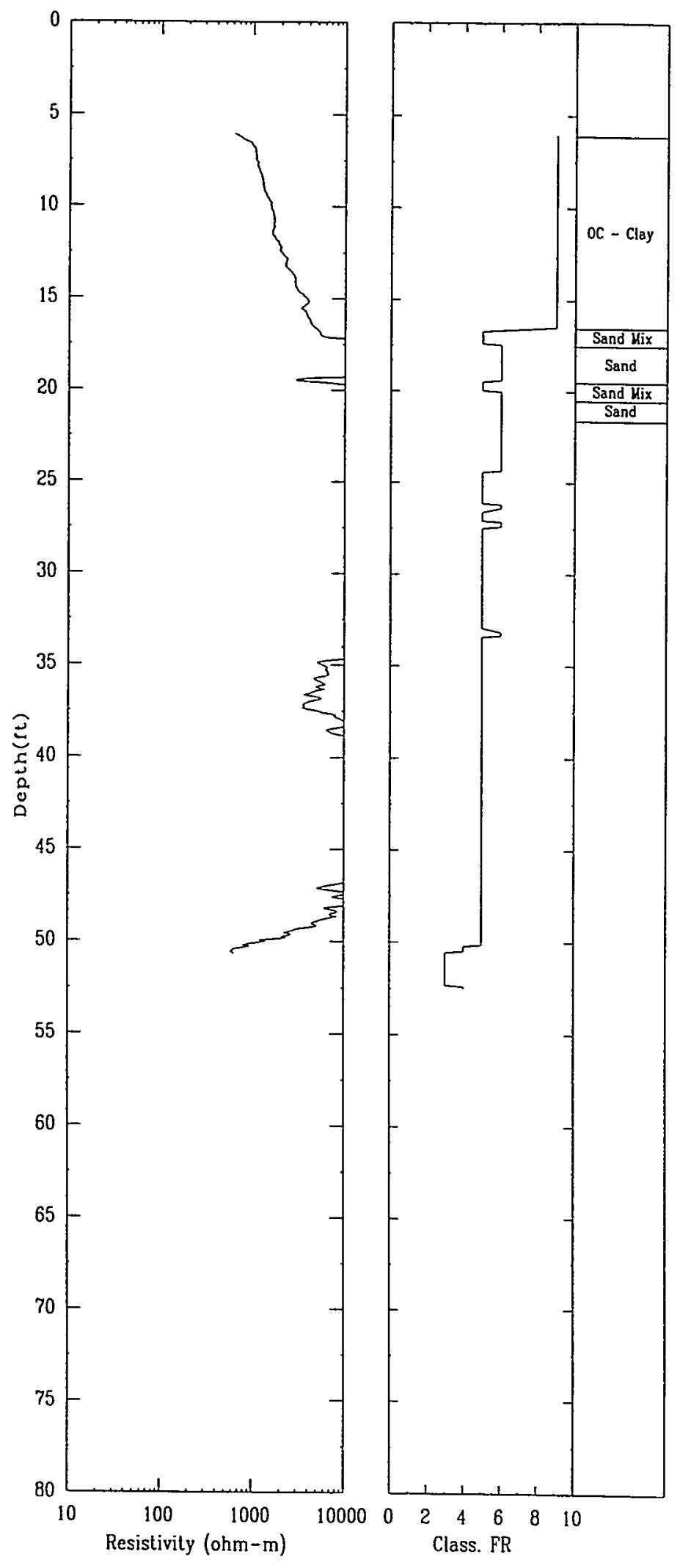



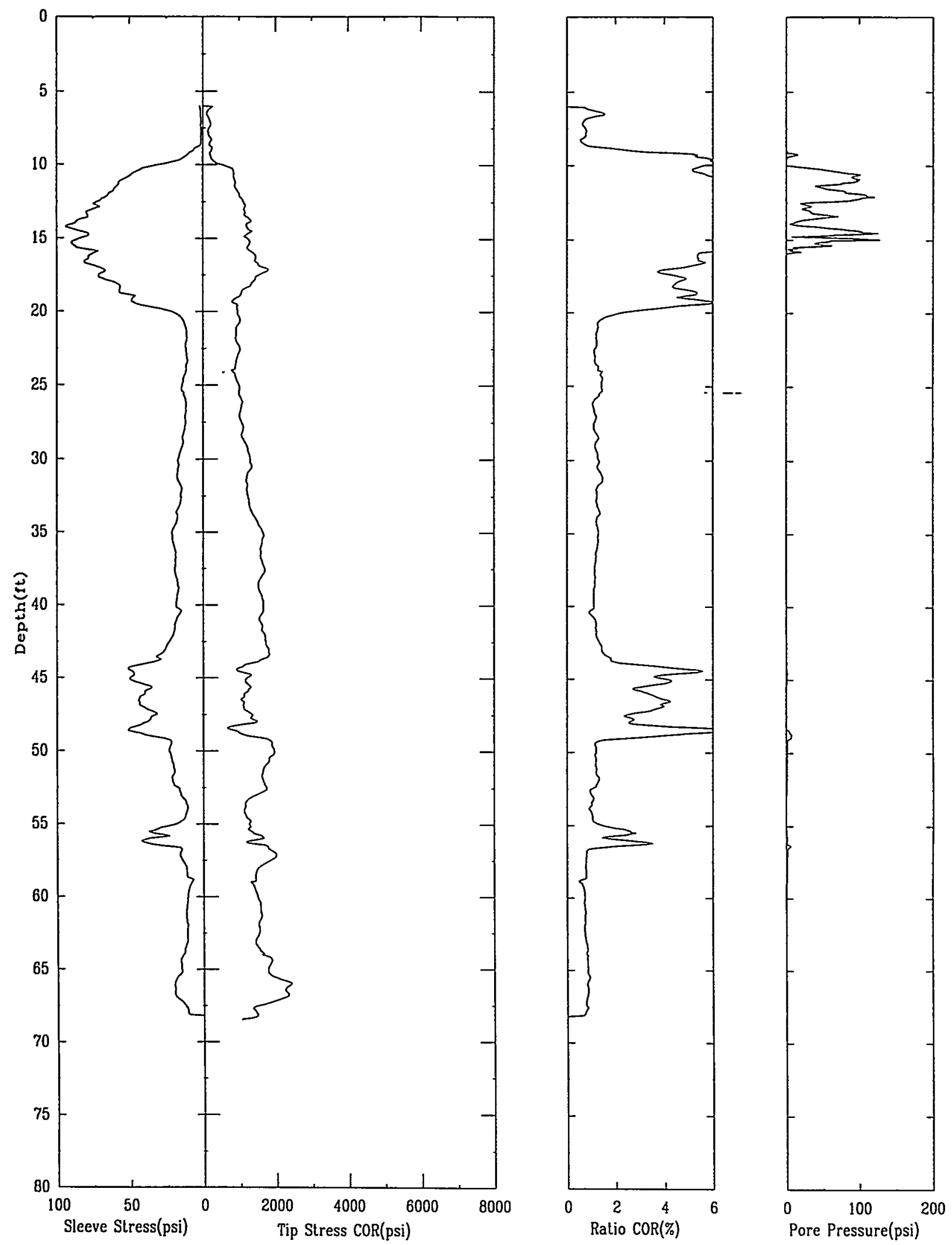


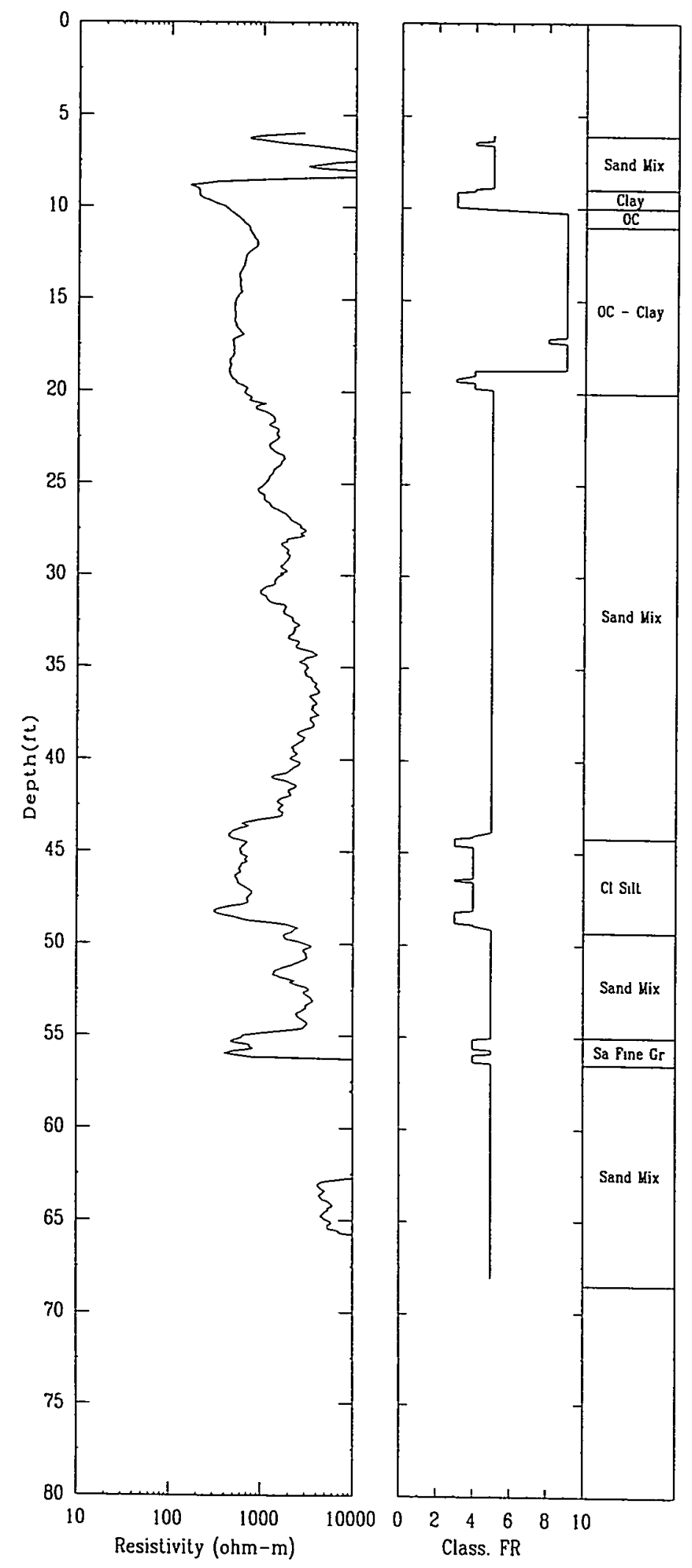



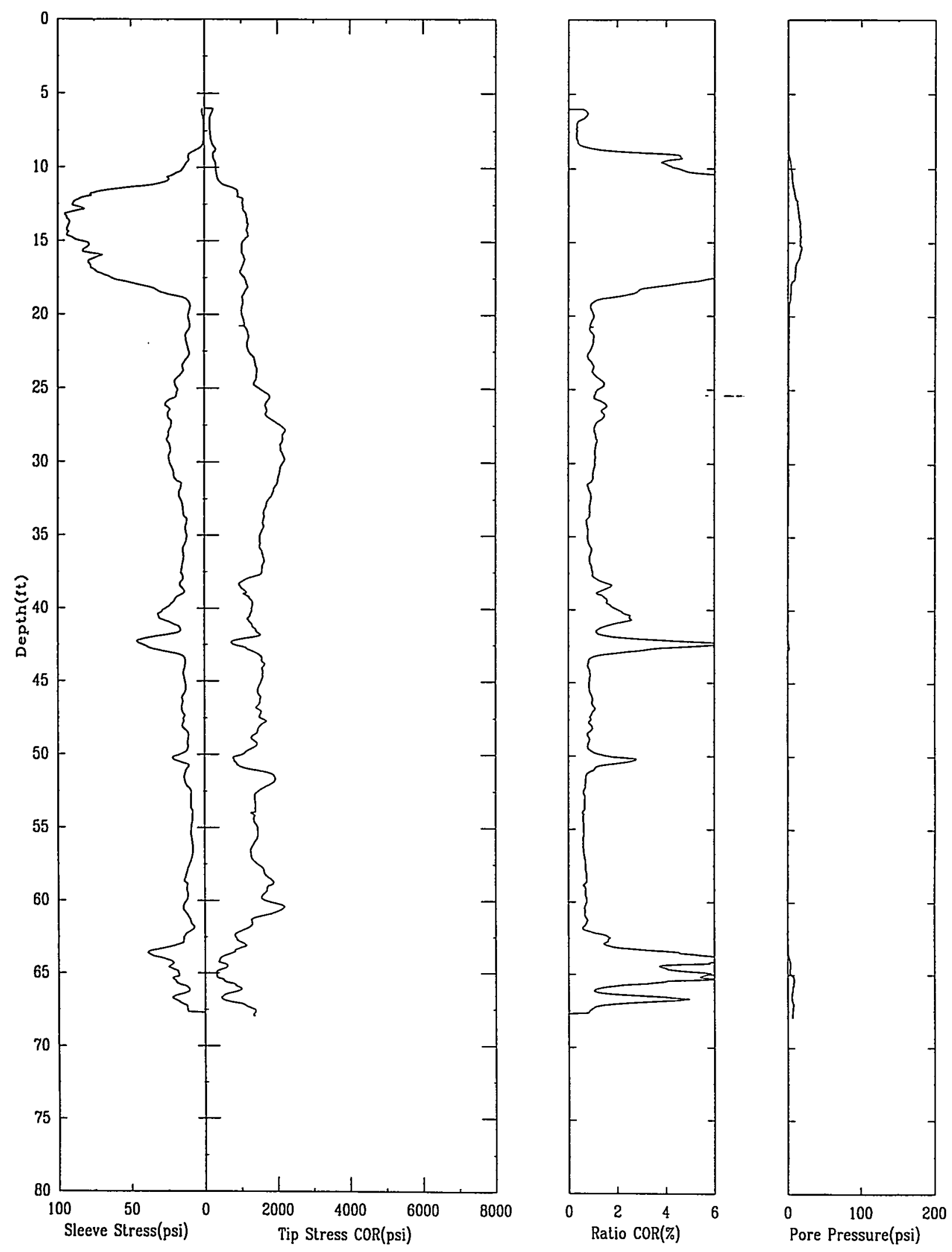


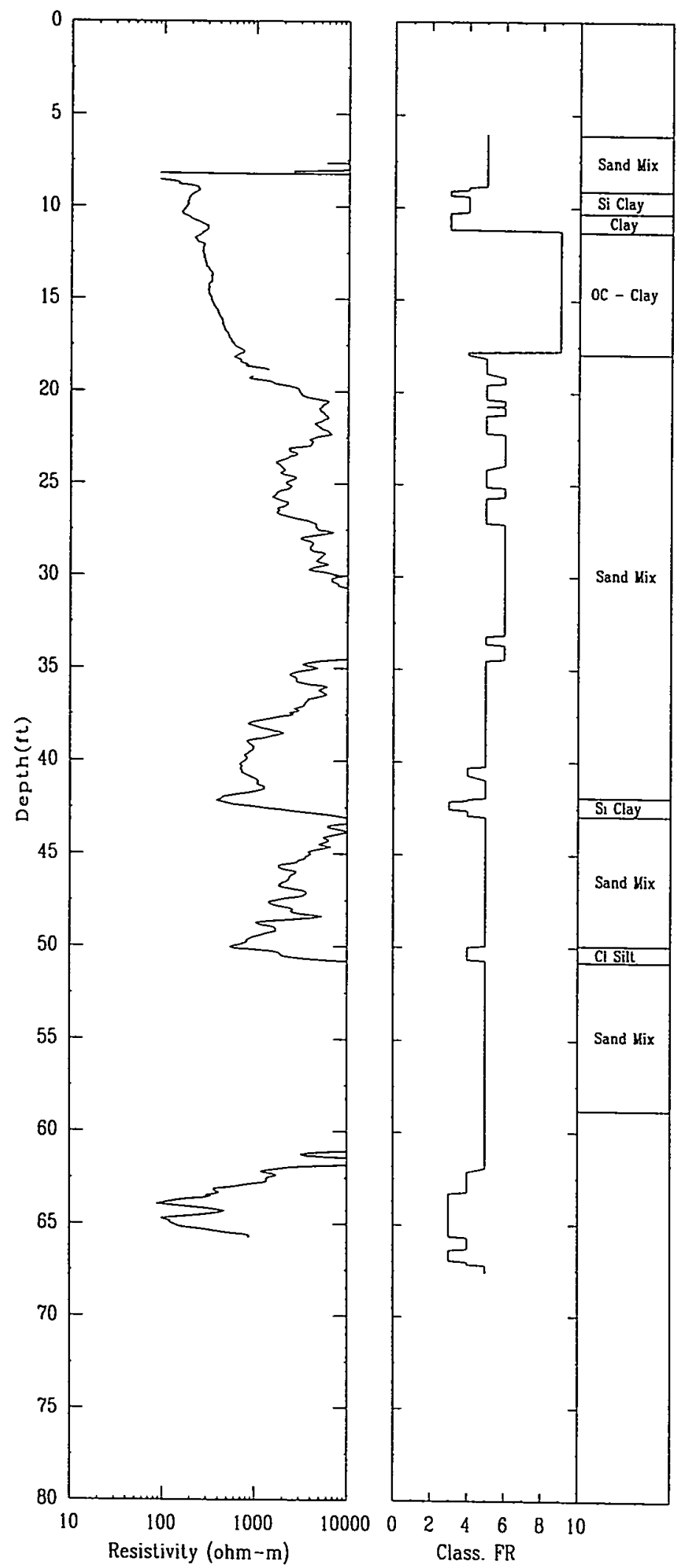




\section{Appendix B: Well Construction Records for Extraction Wells MVE-13 through MVE-22.}




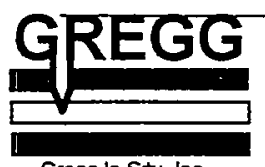

Gregg In Situ, Inc.

GREGG IN SITU, INC.

ENVIRONMENTAL AND GEOTECHNICAL PENETRATION TESTING

Bruce Triplett

Bechtel Savannah River Company

Building $730-2 \mathrm{~B}$

P.O. Box 616

Aiken, SC 29808

\section{Subject: Task \#31 A-14 Outfall Vadose Zone Temperary Piezometers}

Dear Mr. Triplett:

The work was completed using our 25 ton CPT rig and accompanying support rig. The dead weight of the CPT rig is used as a reaction to push the wells to the desired depth using a hydraulic ram located at the center of the truck. The locations is first pushed using a dummy tip to pre-punch the locations to reduce the friction on the well pipe and the potential of clogging the screen as it is being pushed into the subsurface. Once the hole has been pushed then a $21 / 2^{n} \times 3^{n}$ long tip is place on the end of the 5 foot well pipe and cpt rods are then lowered into the well pipe to the tip. The cpt rod is then used to push the tip into the subsurface and the well pipe is pulled down with the tip to the desired depth of the well. This procedure has been very successful in the installation of over 120 of the direct push at the Savannah River Site.

\section{Installation Procedure}

1. A 3" or 4" $\varnothing$ diameter hole is hand augured to a depth of approximately 4'.

2. The locations are first pushed using a $2.5 " \varnothing$ dummy tip to pre-punch the locations to reduce friction on the well point casing as it is pushed into the subsurface..

3. The well point assembly (1.75" ø drive rod, $2 " \emptyset$ well point casing and $2.5^{\prime \prime} \emptyset$ dummy tip) is pushed into the pilot hole.

4. The well point assembly is pushed using the drive rod to the appropriate depth.

5. The drive rod is removed once the well point has reached the desired depth.

6. The casing is capped and a well identification placed on each well.

The attached table provides the well identification with corresponding depths.

If you have any comments please contact me at (803) 642-2781.

Sincerely, GREGG IN SITU, INC.

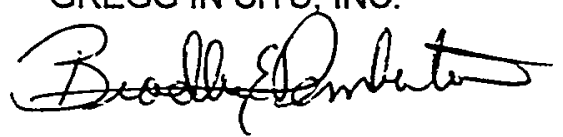

Bradley E Pemberton

General Manager

1359 Silver Bluff Rd Suite G-18 • Aiken, South Carolina • (803) 642-2781•FAX (803) 642-2782

OTHER OFFICES: SIGNAL HILL, SAN FRANCISCO, SEATTLE, KINGWOOD TX, VANCOUVER B.C., EDMONTON ALBERTA 


\section{GREGG Gregg In Situ Inc. Temporary Piezometer Well Summary}

Gregg In Situ, Inc.

\begin{tabular}{|ll|}
\hline Project No.: & Task \#31 \\
Project Location: & Savannah River Site \\
\hline
\end{tabular}

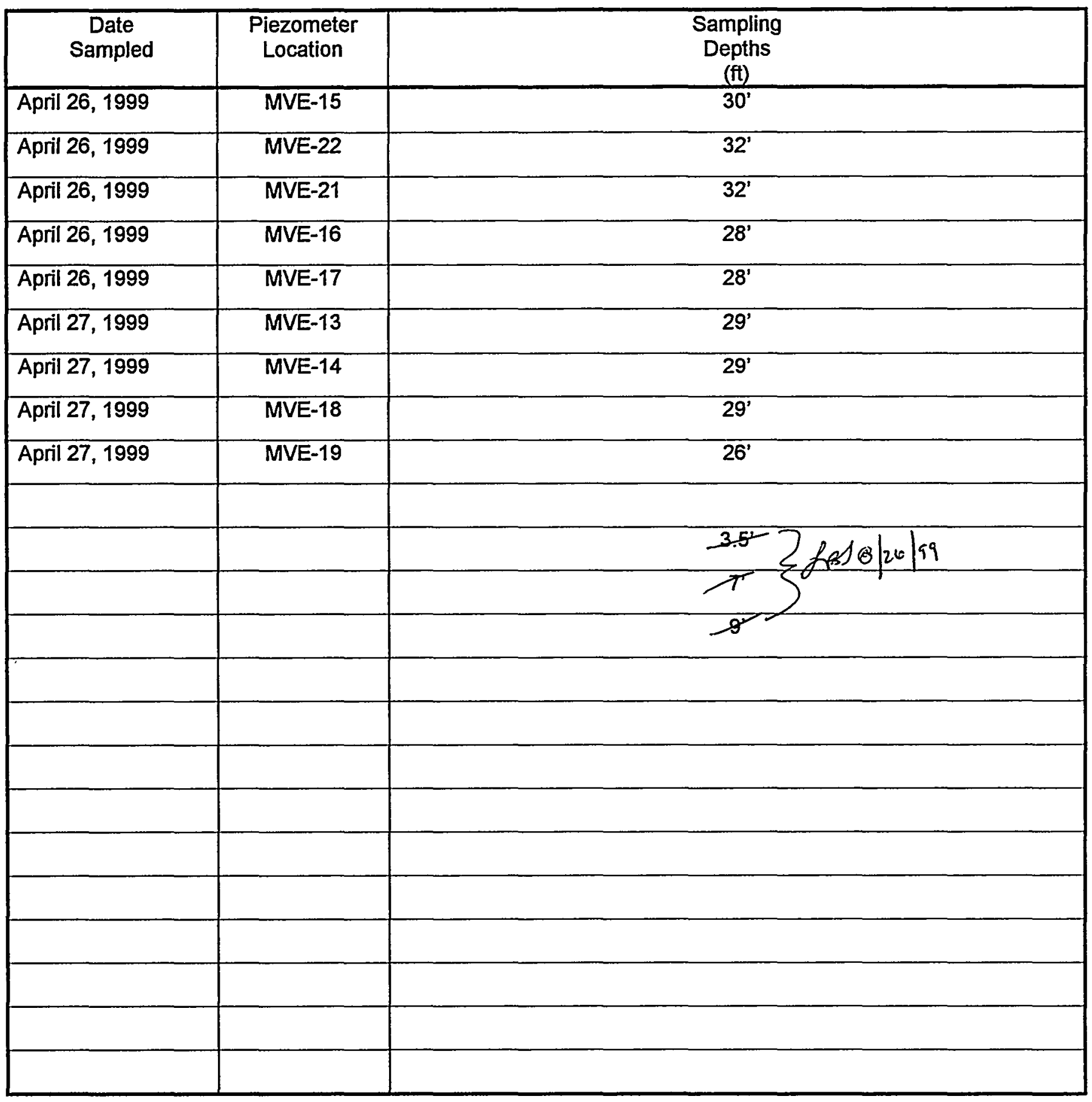




\section{Monitoring Well Construction Diagram}

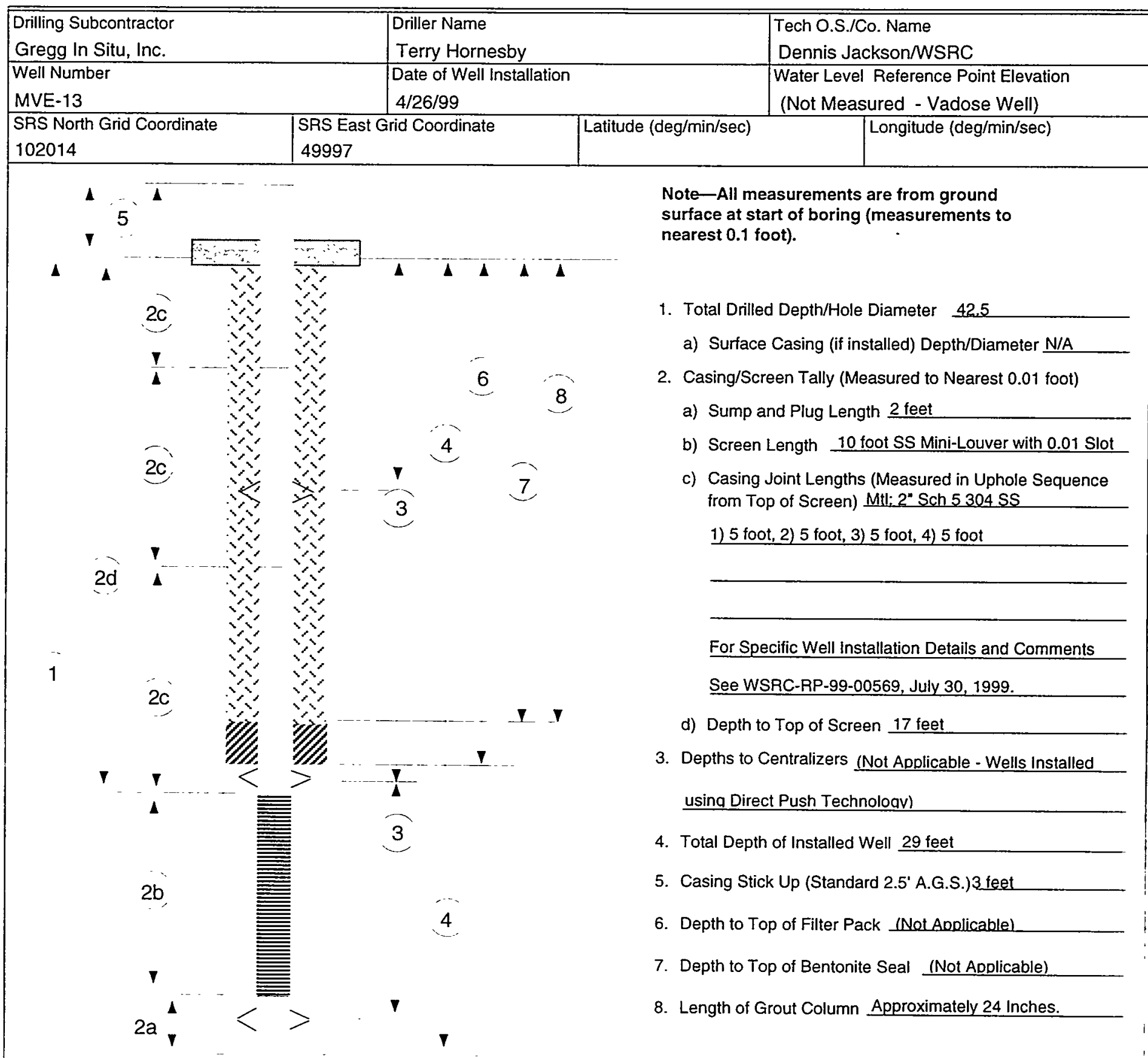


Monitoring Well Construction Diagram

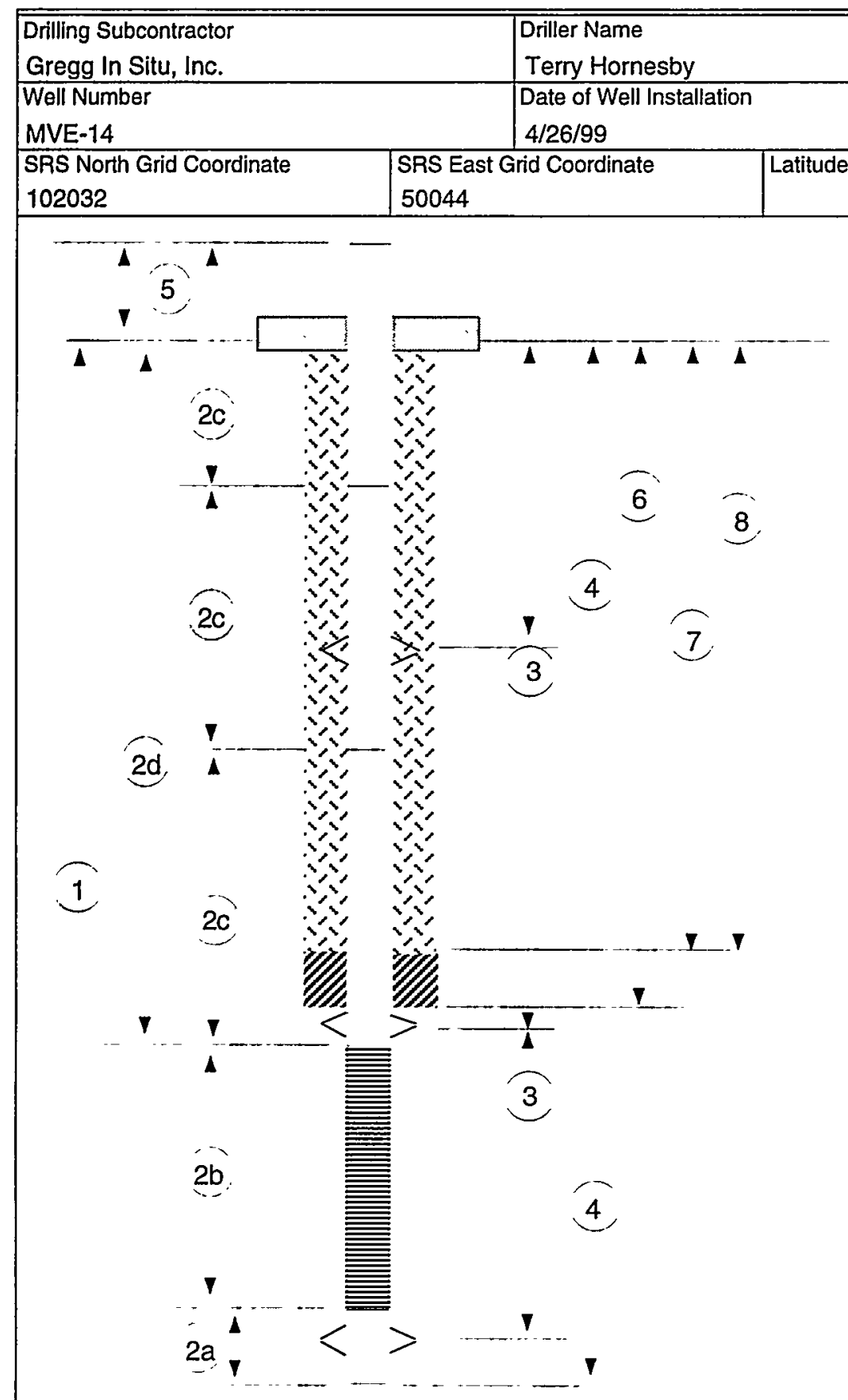

Note-All measurements are from ground surface at start of boring (measurements to nearest 0.1 foot).

1. Total Drilled Depth/Hole Diameter 62.5

a) Surface Casing (if installed) Depth/Diameter N/A

2. Casing/Screen Tally (Measured to Nearest 0.01 foot)

a) Sump and Plug Length 2 feet

b) Screen Length 10 foot SS Minj-Louver with 0.01 Slot

c) Casing Joint Lengths (Measured in Uphole Sequence from Top of Screen) Mtl: 2" Sch 5304 SS

1) 5 foot, 2) 5 foot, 3) 5 foot, 4) 5 foot

For Specific Well Installation Details and Comments

See WSRC-RP-99-00569, July 30, 1999.

d) Depth to Top of Screen 17 feet

3. Depths to Centralizers (Not Applicable - Wells Installed using Direct Push Technoloav)

4. Total Depth of Installed Well 29 feet

5. Casing Stick Up (Standard 2.5' A.G.S.) 3 feet

6. Depth to Top of Filter Pack (Not Aoplicable)

7. Depth to Top of Bentonite Seal (Not Applicable)

8. Length of Grout Column Approximately 24 Inches. 


\section{Monitoring Well Construction Diagram}

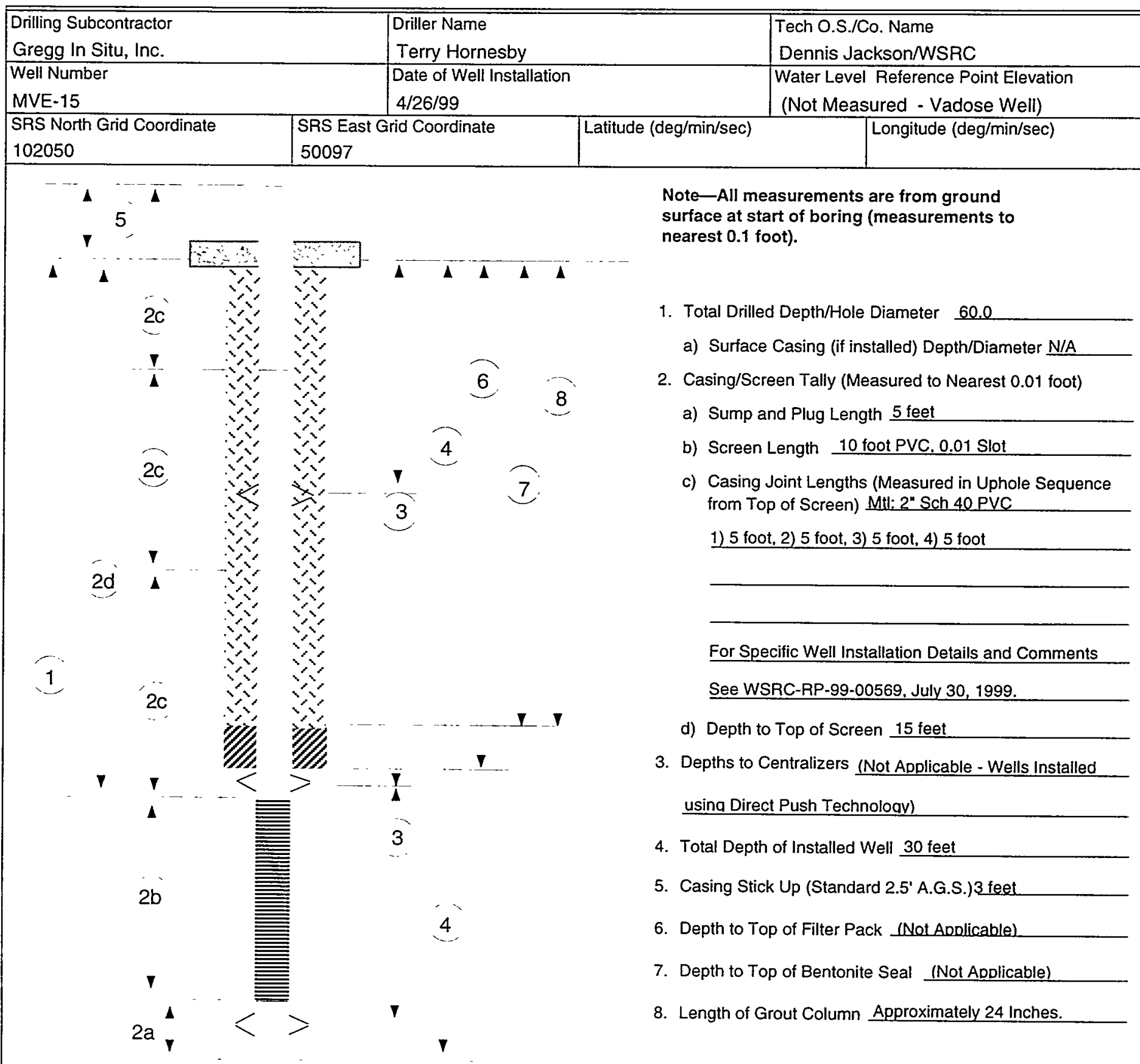


Monitoring Well Construction Diagram

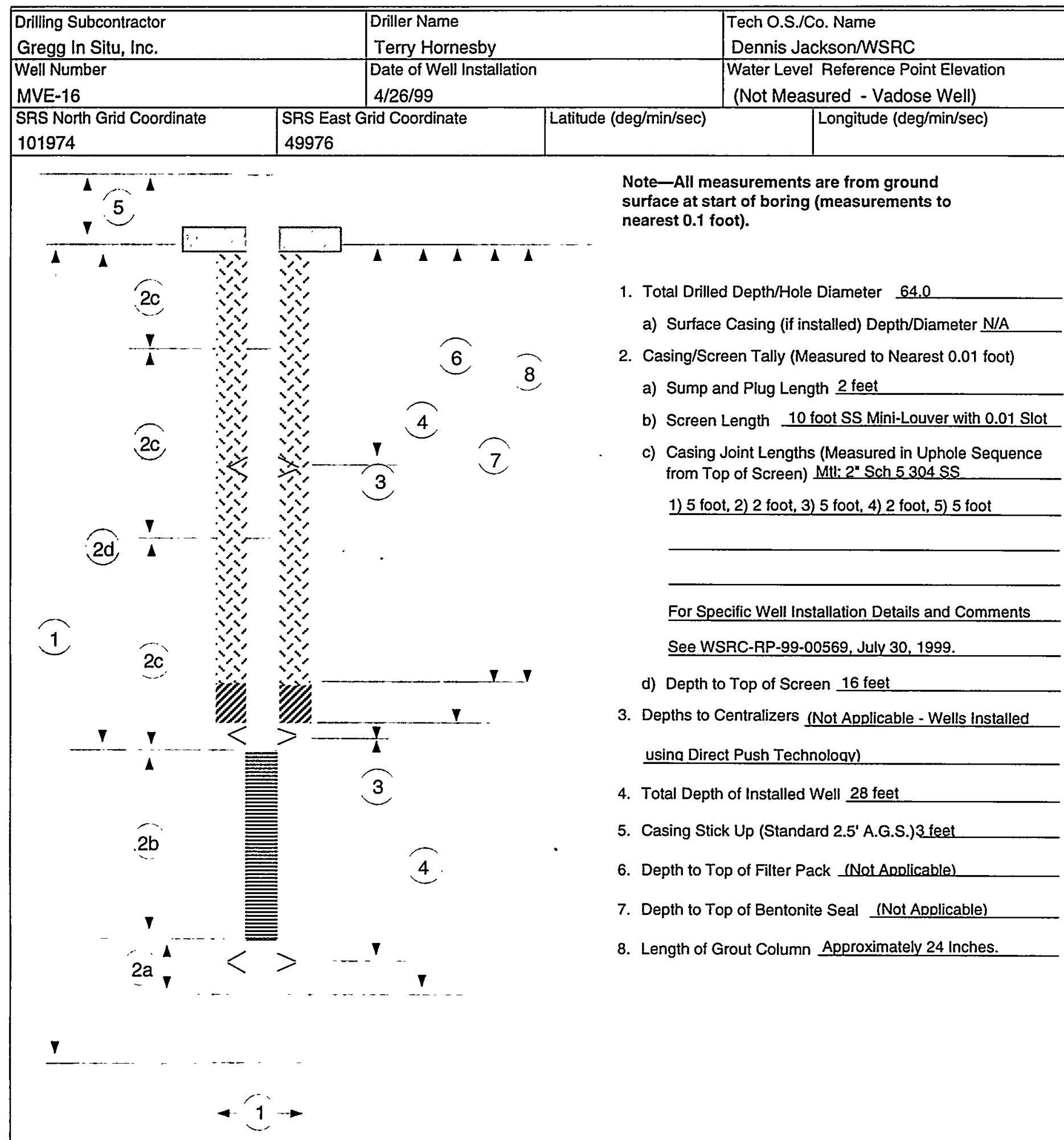




\section{Monitoring Well Construction Diagram}

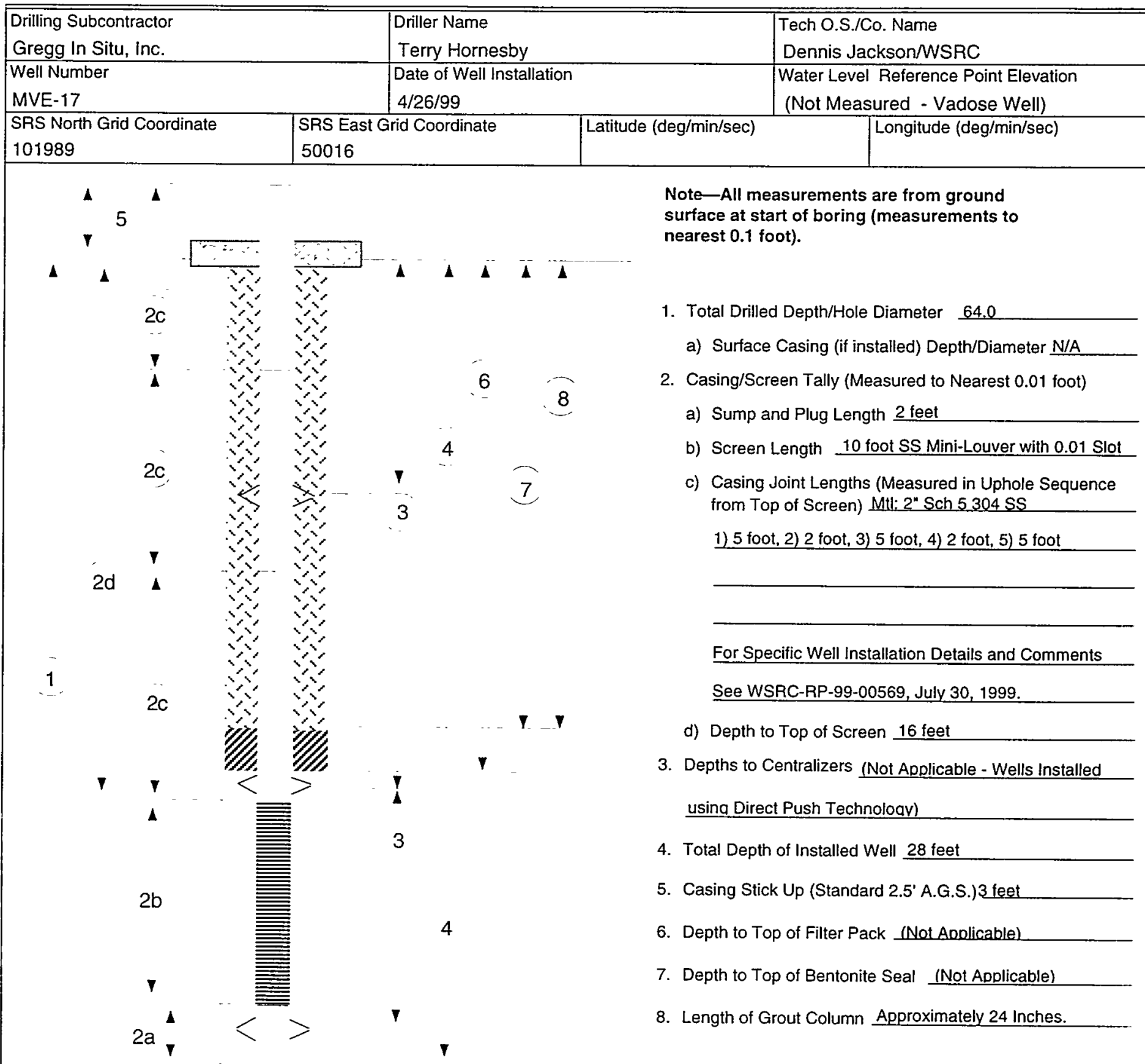


Monitoring Well Construction Diagram

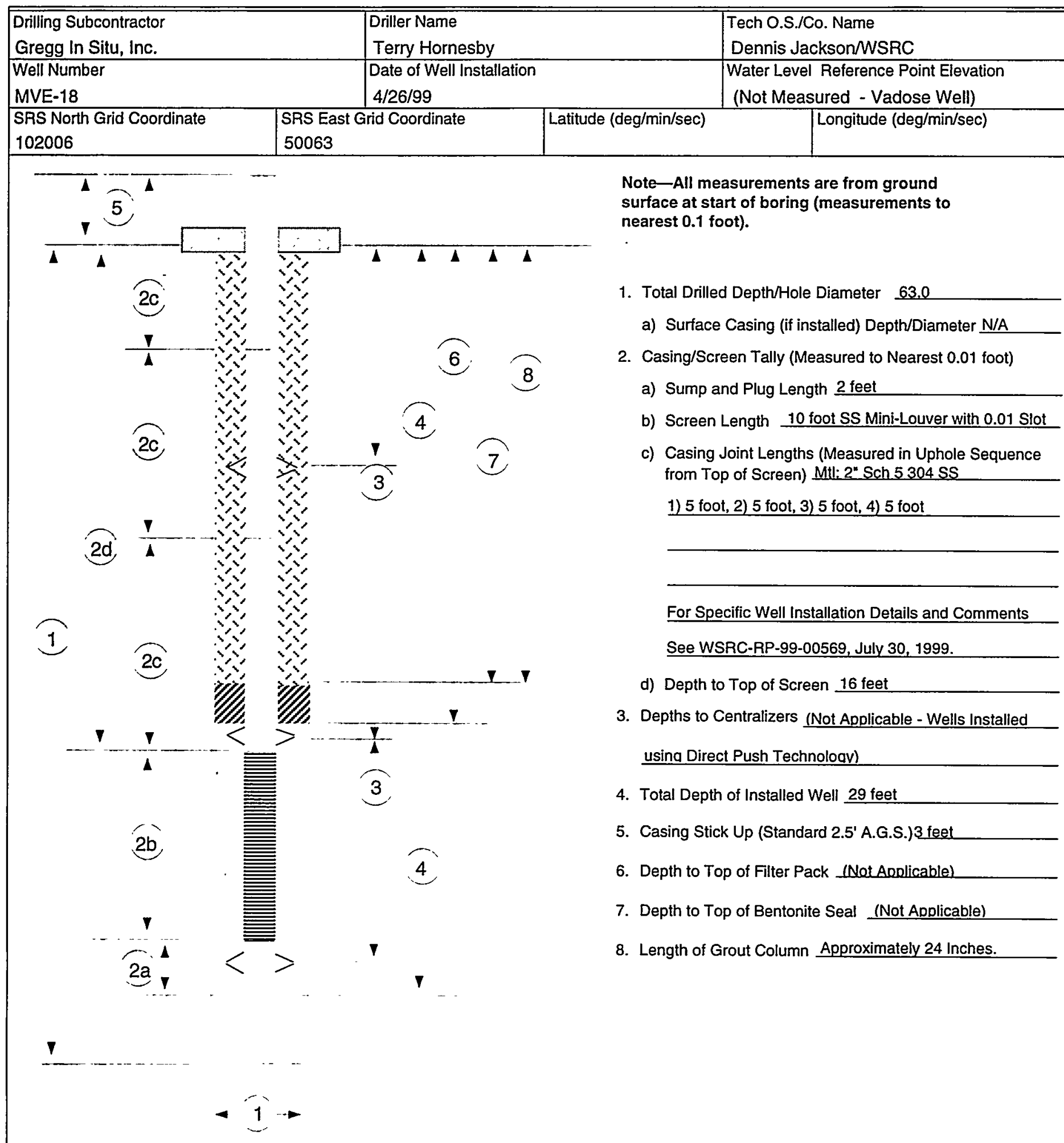


Monitoring Well Construction Diagram

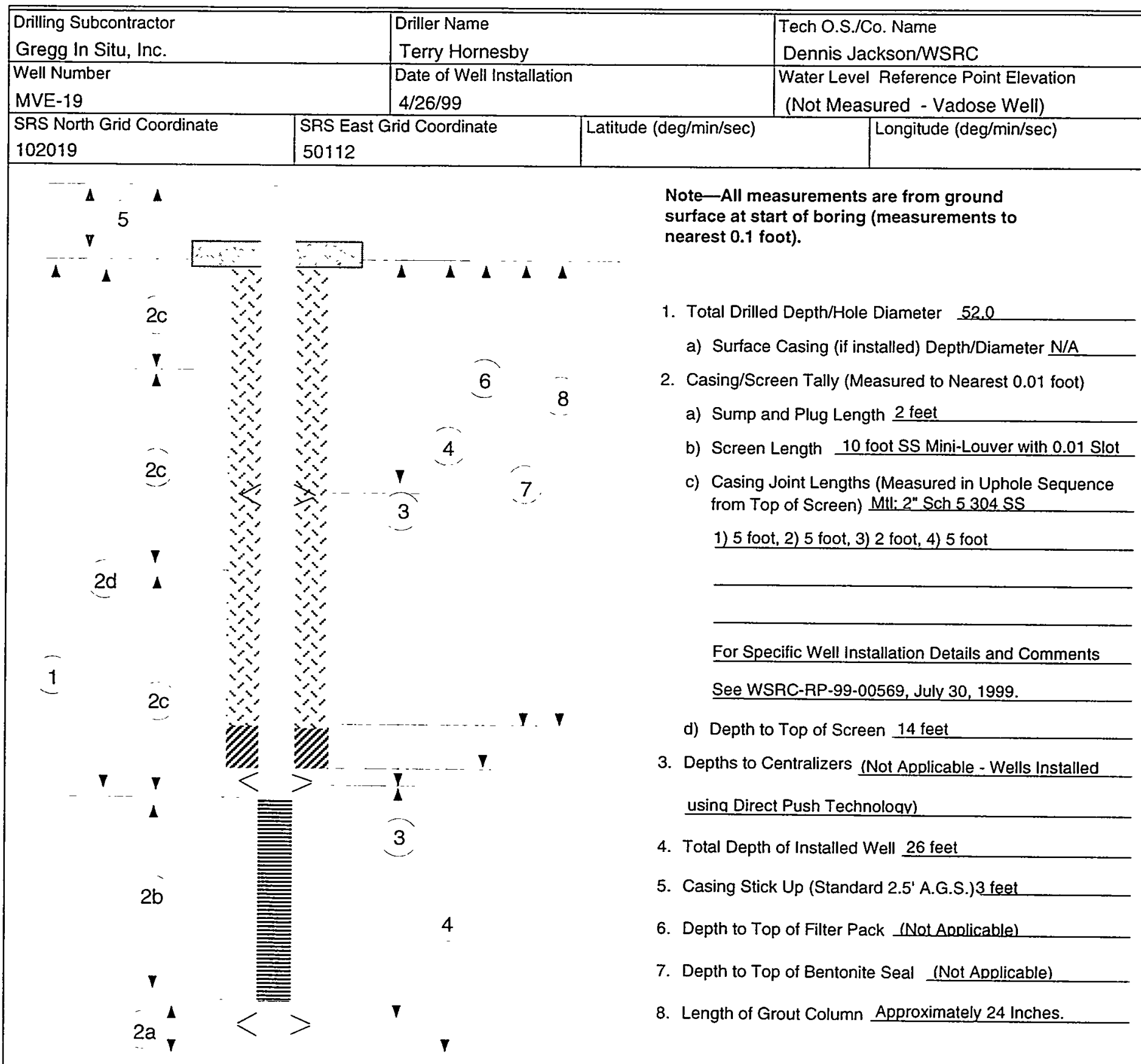




\section{Monitoring Well Construction Diagram}

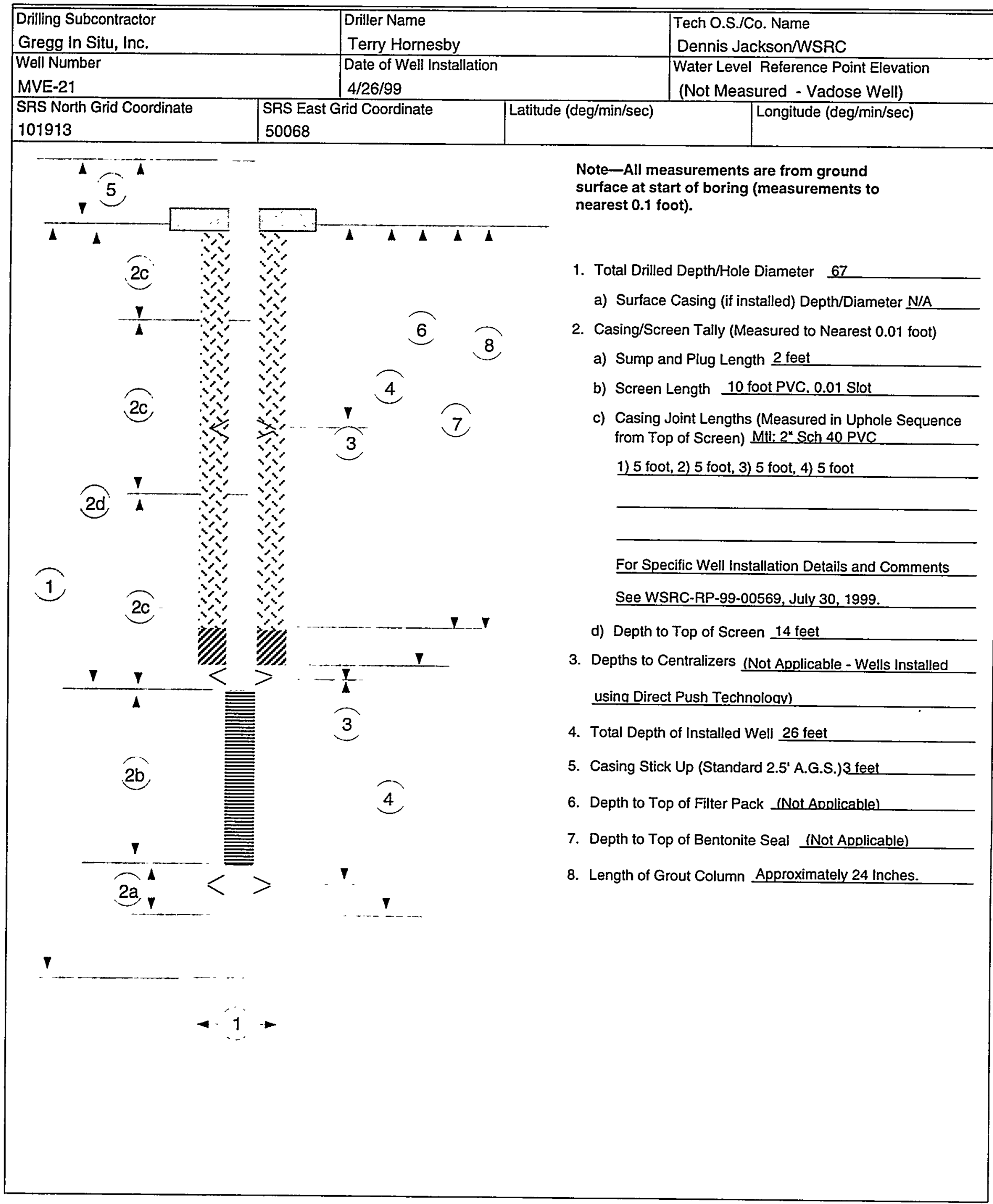


Monitoring Well Construction Diagram

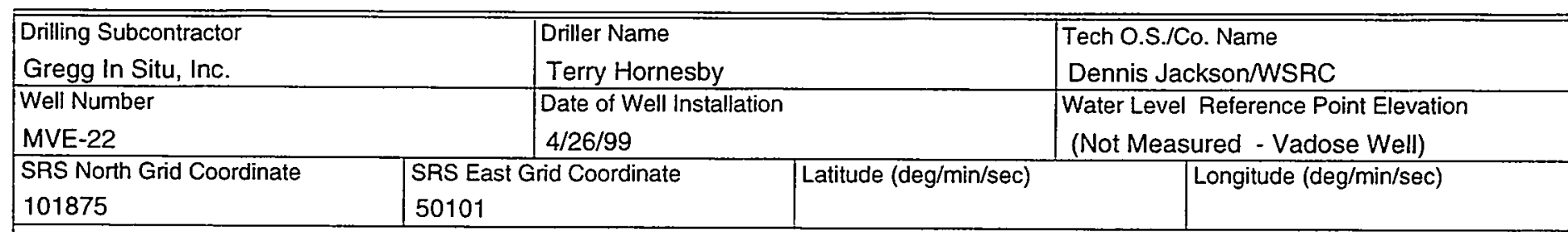

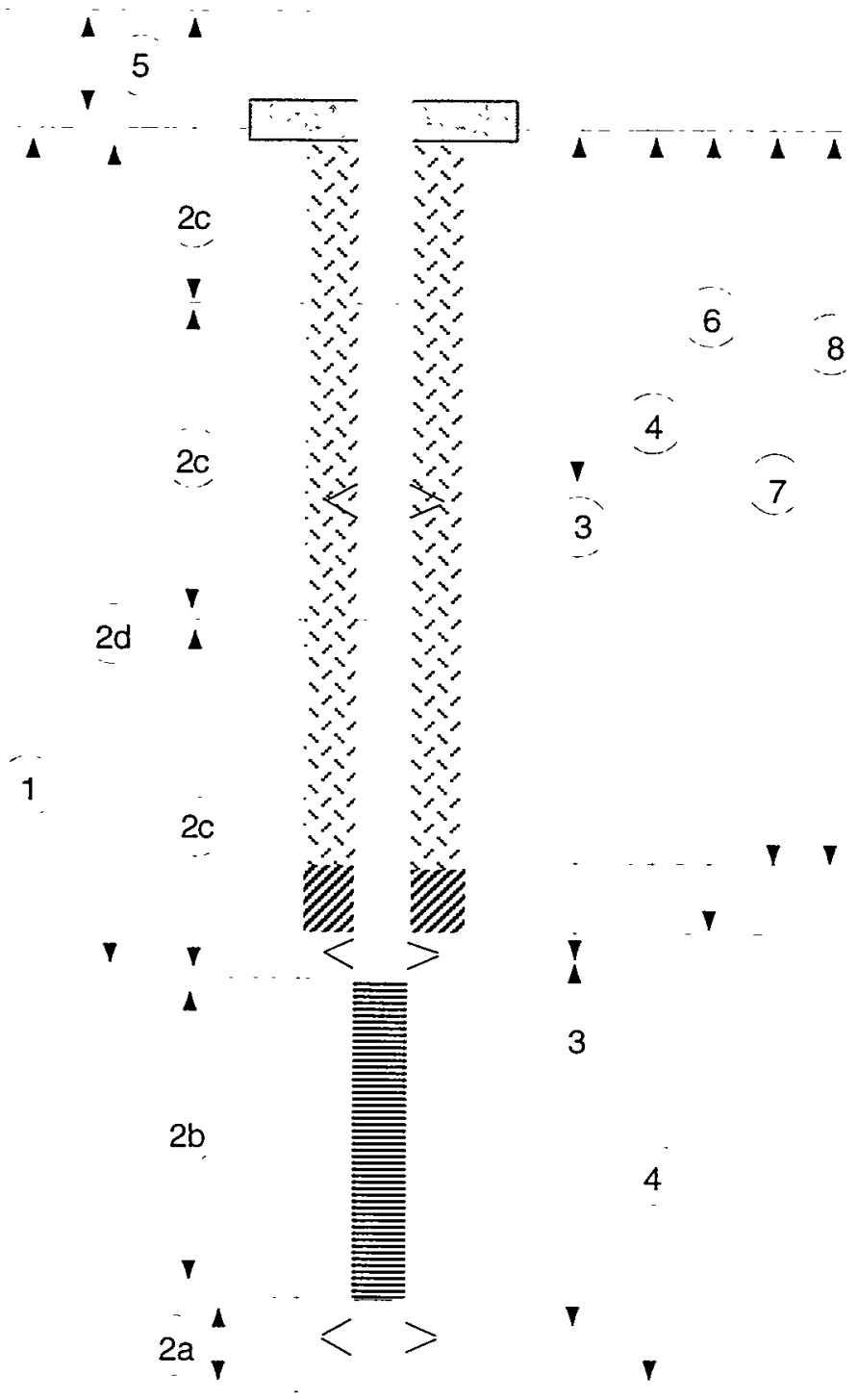

Note-All measurements are from ground surface at start of boring (measurements to nearest 0.1 foot).

1. Total Drilled Depth/Hole Diameter 67

a) Surface Casing (if installed) Depth/Diameter N/A

2. Casing/Screen Tally (Measured to Nearest 0.01 foot)

a) Sump and Plug Length 2 feet

b) Screen Length 10 foot PVC, 0.01 Slot

c) Casing Joint Lengths (Measured in Uphole Sequence from Top of Screen) Mitl: 2" Sch 40 PVC

1) 5 foot, 2) 5 foot, 3) 5 foot, 4) 5 foot

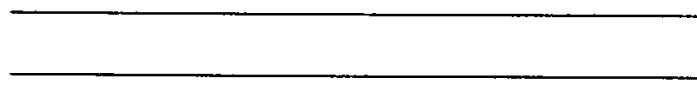

For Specific Well Installation Details and Comments

See WSRC-RP-99-00569, July 30, 1999.

d) Depth to Top of Screen 14 feet

3. Depths to Centralizers (Not Applicable - Wells Installed using Direct Push Technoloav)

4. Total Depth of Installed Well 26 feet

5. Casing Stick Up (Standard 2.5' A.G.S.) 3 feet

6. Depth to Top of Filter Pack (Not Aonlicable)

7. Depth to Top of Bentonite Seal (Not Applicable)

8. Length of Grout Column Approximately 24 Inches. 